Andrews University

Digital Commons @ Andrews University

\title{
A Strategy To Evangelize the Members of Siu San Wan Social Center for the Elderly in Hong Kong
}

Linda Muoi Tsui

Andrews University

Follow this and additional works at: https://digitalcommons.andrews.edu/dmin

Part of the Practical Theology Commons

\section{Recommended Citation}

Tsui, Linda Muoi, "A Strategy To Evangelize the Members of Siu San Wan Social Center for the Elderly in Hong Kong" (2011). Professional Dissertations DMin. 483.

https://dx.doi.org/10.32597/dmin/483

https://digitalcommons.andrews.edu/dmin/483

This Project Report is brought to you for free and open access by the Graduate Research at Digital Commons @ Andrews University. It has been accepted for inclusion in Professional Dissertations DMin by an authorized administrator of Digital Commons @ Andrews University. For more information, please contact repository@andrews.edu. 


\title{
ABSTRACT \\ A STRATEGY TO EVANGELIZE THE MEMBERS \\ OF SIU SAI WAN SOCIAL CENTER FOR \\ THE ELDERLY IN HONG KONG
}

\section{by}

\author{
Linda Muoi Tsui
}

Adviser: S. Joseph Kidder 


\title{
ABSTRACT OF GRADUATE STUDENT RESEARCH
}

\author{
Dissertation
}

\author{
Andrews University \\ Theological Seminary
}

\section{Title: A STRATEGY TO EVANGELIZE THE MEMBERS OF SIU SAI WAN SOCIAL CENTER FOR THE ELDERLY IN HONG KONG}

Name of researcher: Linda Muoi Tsui

Name and degree of adviser: S. Joseph Kidder, D.Min.

Date completed: April 2011

\section{Problem}

The number of senior citizens in Hong Kong is increasing. By 2036, approximately one-fourth of the population of Hong Kong will fall into the elderly category, representing a challenge to the government as well as to the church.

However, there is a scarcity of research done on elderly evangelism and an accompanying dearth of literature on the topic, therefore there is a need for a research study on how to evangelize the elderly, to make a significant contribution to an increasingly important ministry of the church.

\section{Method}

A "Four-stage Elderly Evangelism Model" was developed and implemented to 
reach the members of Siu Sai Wan Social Center for the Elderly of Hong Kong-Macao Conference of Seventh-day Adventists. It consisted of four biblical principles:

(1) visitation evangelism, (2) friendship evangelism, (3) culturally-relevant competent programs, and (4) dynamic worship. The model was divided into two parts, the "going" and "coming" parts. The "going" part in which members go out and reach the people included visitation evangelism and friendship evangelism. The "coming" part, meaning that the church encourages the people to come to them, was based on providing competent programs and worship events to attract the people to join the members. The model was implemented and tested to measure its effectiveness.

\section{Results}

The survey of the model showed an overall mean of 4.18 (on a scale of one to five), this represents a gain of $26.94 \%$. The respective gain of each principle is: (1) $39.2 \%$ in visitation evangelism, (2) $18.88 \%$ in friendship evangelism, (3) $29.79 \%$ in culturallyrelevant competent programs, and (4) $28.78 \%$ in dynamic worship. On the other hand, the elderly baptismal figures showed a significant gain of $79.31 \%$. It indicated the model was working and successfully implemented.

\section{Conclusions}

All four aspects of the Elderly Evangelism Model proved to be valid and workable. This model will be a valuable tool on how to evangelize elderly Chinese. Elderly Chinese generally have inherited the largest portion of traditional Chinese culture. This model may also fit to evangelize other age groups when the programs and worships are designed to be culturally-relevant and seeker sensitive. 
Andrews University

Seventh-day Adventist Theological Seminary

\title{
A STRATEGY TO EVANGELIZE THE MEMBERS \\ OF SIU SAI WAN SOCIAL CENTER FOR \\ THE ELDERLY IN HONG KONG
}

\author{
A Dissertation \\ Presented in Partial Fulfillment \\ of the Requirements for the Degree \\ Doctor of Ministry
}

by

Linda Muoi Tsui

April 2011 
(C) Copyright by Linda Muoi Tsui 2011

All Rights Reserved 


\title{
A STRATEGY TO EVANGELIZE THE MEMBERS OF SIU SAI WAN SOCIAL CENTER FOR \\ THE ELDERLY IN HONG KONG
}

\author{
A dissertation \\ presented in partial fulfillment \\ of the requirements for the degree \\ Doctor of Ministry
}

by

Linda Muoi Tsui

APPROVED BY THE COMMITTEE:

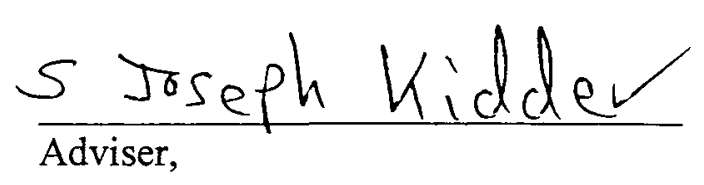

S. Joseph Kidder
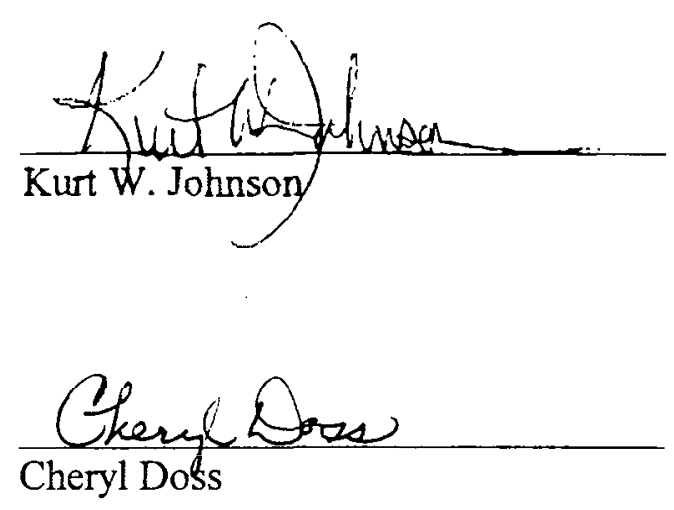

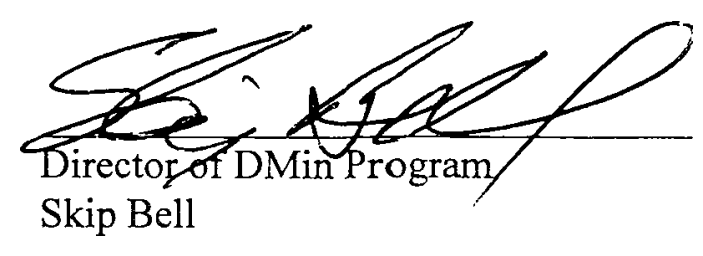

Denis Fontin

Dean of Theological Seminary

Denis Fortin 
Dedicated to my dearest parents who taught me how to be "respectful," "loving," and "caring" for others. As it turned out, these three words formed the key concepts in this elderly evangelism project. My father was a teacher throughout my whole life, my mother was my role model of love, and together they prayed that I would enter into the ministry. Without them, I would not be as successful! 


\section{TABLE OF CONTENTS}

LIST OF TABLES $\ldots \ldots \ldots \ldots \ldots \ldots \ldots \ldots \ldots \ldots \ldots \ldots \ldots \ldots \ldots \ldots \ldots \ldots \ldots \ldots$ viii

LIST OF ABBREVIATIONS $\ldots \ldots \ldots \ldots \ldots \ldots \ldots \ldots \ldots \ldots \ldots \ldots \ldots \ldots \ldots \ldots \ldots$ ix

ACKNOWLEDGMENTS $\ldots \ldots \ldots \ldots \ldots \ldots \ldots \ldots \ldots \ldots \ldots \ldots \ldots \ldots \ldots \ldots \ldots \ldots, \quad \mathrm{x}$

Chapter

I. INTRODUCTION $\ldots \ldots \ldots \ldots \ldots \ldots \ldots \ldots \ldots \ldots \ldots \ldots \ldots \ldots \ldots \ldots$

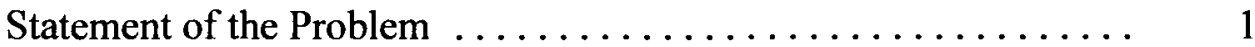

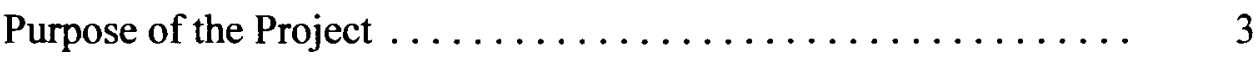

Justification for the Project $\ldots \ldots \ldots \ldots \ldots \ldots \ldots \ldots \ldots \ldots, 3$

Definition of Terms .......................... 5

Limitations of the Project ...................... 7

Delimitations of the Project $\ldots \ldots \ldots \ldots \ldots \ldots \ldots \ldots \ldots$

Description of Methodology . . . . . . . . . . . . . . 9

II. THEOLOGICAL FOUNDATIONS FOR ELDERLY EVANGELISM .............................. 12

Biblical Perspectives on Contextualized Evangelism ......... 12

The Biblical View of the World and Its Implications for

Elderly Evangelism ....................... 13

A Biblical View of the World ................... 13

The Church and Human Needs ................... 14

Attitude Toward Those in Need-Compassion ........ 15

Attitude Toward Aliens and Refugees-Hospitality...... 17

Attitude to Loneliness-Fellowship .............. 18

Its Implications for Elderly Evangelism . . . . . . . . . . . 19

The Two Mandates .......................... 21

The Great Commission ...................... 22

The Great Commandment .................... 24

Benevolent Work and Blessings $\ldots \ldots \ldots \ldots \ldots \ldots \ldots .25$

Blessings in the Bible ....................... 27

Biblical Meaning of Blessing ................. 27

Who Can Receive the Blessing .................. 29

Blessings for the Elderly ..................... 29

Application of Blessings in Elderly Evangelism......... 31 
Elderly Characteristics and Characters $\ldots \ldots \ldots \ldots \ldots \ldots \ldots, \quad 32$

The Characteristics of Elderly $\ldots \ldots \ldots \ldots \ldots \ldots \ldots \ldots . \quad 32$

Elderly Need Respect .................... $\quad 32$

Elderly Need Submission from the Young .......... 34

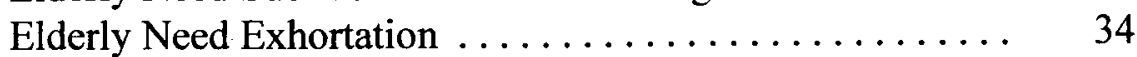

Elderly Need Love ..................... 37

Four Notable Elderly Characters in the Bible .......... $\quad 37$

Abraham-A Trusting Hero $\ldots \ldots \ldots \ldots \ldots \ldots \ldots \ldots . \quad 38$

Daniel-A Prayerful Hero ...................... 38

Caleb-A Courageous Hero .................... 39

Moses-A Humble Hero .................... 39

Three Elderly Conversions . . . . . . . . . . . . . . . . . 39

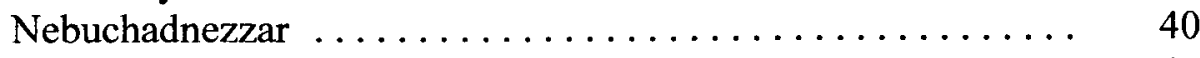

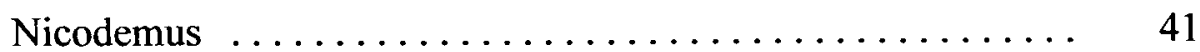

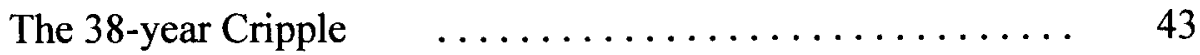

Ellen White and Elderly Evangelism $\ldots \ldots \ldots \ldots \ldots \ldots \ldots . \quad 44$

Summary $\ldots \ldots \ldots \ldots \ldots \ldots \ldots \ldots \ldots \ldots \ldots \ldots \ldots \ldots, 48$

III. THE SIU SAI WAN SOCIAL CENTER EVANGELISTIC

CHALLENGES $\ldots \ldots \ldots \ldots \ldots \ldots \ldots \ldots \ldots \ldots \ldots \ldots \ldots \ldots \ldots \ldots \ldots$

The Elderly and Their Challenges $\ldots \ldots \ldots \ldots \ldots \ldots \ldots \ldots .50$

The Elderly Population $\ldots \ldots \ldots \ldots \ldots \ldots \ldots \ldots \ldots . \quad 50$

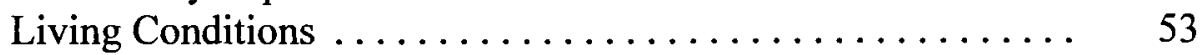

Educational Level .......................... 55

Worldview of Elderly in Hong Kong $\ldots \ldots \ldots \ldots \ldots \ldots \ldots .56$

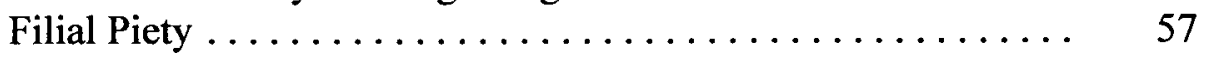

Ancestor Worship ........................ 60

Five-Step Witnessing Approach to Ancestor Worship ....... 62

Values in Elderly Thinking Patterns ............... 64

The Biblically Shaped Worldview and Its Benefits........ 66

Siu Sai Wan Social Center Profile $\ldots \ldots \ldots \ldots \ldots \ldots \ldots \ldots .68$

Summary $\ldots \ldots \ldots \ldots \ldots \ldots \ldots \ldots \ldots \ldots \ldots \ldots \ldots \ldots \ldots, \quad 71$

IV. FOUR-STAGE ELDERLY EVANGLISM MODEL $\ldots \ldots \ldots \ldots \ldots 73$

Introduction .............................. 73

Principle 1: From House to House $\ldots \ldots \ldots \ldots \ldots \ldots \ldots \ldots, 74$

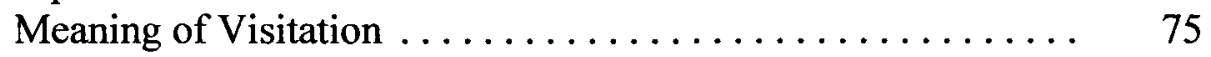

Importance of Visitation ..................... 76

Benefits of Visitation ...................... 78

Biblical Examples of Visitation $\ldots \ldots \ldots \ldots \ldots \ldots \ldots \ldots \quad 78$

God the Father Visited $\ldots \ldots \ldots \ldots \ldots \ldots \ldots \ldots \ldots, 79$

Jesus Visited $\ldots \ldots \ldots \ldots \ldots \ldots \ldots \ldots \ldots \ldots \ldots, \quad 80$

Paul Visited ............................ $\quad 80$

Visitation Evangelism ..................... 81 
Five Purposes in Visitation ................. $\quad 82$

Five Effective Keys to Elderly Visitation .......... 82

Principle 2: From Confrontational Evangelism to Friendship

Evangelism .......................... 84

Importance of Friendship Evangelism $\ldots \ldots \ldots \ldots \ldots \ldots .84$

Meaning of Friendship Evangelism $\ldots \ldots \ldots \ldots \ldots \ldots \ldots$.

Biblical Examples of Friendship Evangelism . . . . . . . . . 86

The Trinity: Friend of Saints and Sinners . . . . . . . . 86

Philip and Nathanael .................... 87

Matthew and His Tax Collector Friends ........... $\quad 88$

Four Lesser Known Friendship Evangelists ......... $\quad 88$

The Importance of Friendship Evangelism in the

Four-stage Elderly Evangelism Model . . . . . . . . . $\quad 89$

Three Important Attitudes in Elderly Friendship Evangelism . . 90

Principle 3: From Chinese Festivals to Celebration and Feast .... 91

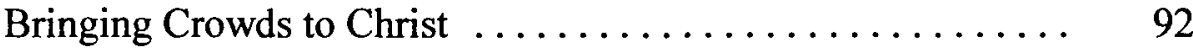

Hospitality ............................. 94

High Quality and Culturally-relevant ............... 95

Culturally-Relevant Programs ................... $\quad 96$

Gospel Tea Party . . . . . . . . . . . . . . . . . . . 97

Senior Citizen's Day ...................... 97

Mother's Day and Father's Day .............. 97

Principle 4: From Worshipping Forefathers to Worshipping the

Heavenly Father $\ldots \ldots \ldots \ldots \ldots \ldots \ldots \ldots \ldots . .96 \ldots$

The Importance of Worship $\ldots \ldots \ldots \ldots \ldots \ldots \ldots \ldots . \quad 98$

Dynamic Worship .......................... 99

Worship His Greatness ................... 100

Worship with Gladness . . . . . . . . . . . . . . . . 101

Worship with Gray Hair .................... 103

Warm Friendship in the Worship Environment ........ 104

Joyful Music .......................... 105

Worship Preaching $\ldots \ldots \ldots \ldots \ldots \ldots \ldots \ldots \ldots, 106$

Summary ............................. 108

V. DESCRIPTION OF THE PROJECT $\ldots \ldots \ldots \ldots \ldots \ldots \ldots \ldots \ldots .110$

Development of the Four-stage Elderly Evangelism Model ...... 110

Experiential ............................ 110

Theoretical ......................... 112

Implementation of the Four-stage Elderly Evangelism Model .... 113

From House to House . . . . . . . . . . . . . . . . . 115

Training $\ldots \ldots \ldots \ldots \ldots \ldots \ldots \ldots \ldots \ldots \ldots \ldots \ldots \ldots \ldots \ldots, 116$

Visitation Groups $\ldots \ldots \ldots \ldots \ldots \ldots \ldots \ldots \ldots \ldots \ldots \ldots \ldots$

Four Major Stages of Visitation ............... 118

Ten Skills in a Visit ....................... 118

Two Key Formulas for Organizing Visitation ........ 119 
From Confrontational Evangelism to Friendship Evangelism . . 119

Caring Ministry ....................... 120

Learning Classes ...................... 120

From Chinese Festivals to Celebration and Feast ......... 122

Chinese New Year ....................... 124

Mid-Autumn Festival and Dragon Boat Festival ....... 124

Senior Citizen's Day and Christmas .............. 125

Mother's Day and Father's Day ............... 125

Gospel Tea Party ...................... 125

From Worshipping Forefathers to Worshipping the

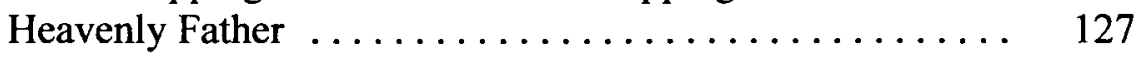

Gospel Opera Songs . . . . . . . . . . . . . . . 127

Preaching ............................. 127

Summary ............................. 129

VI. EVALUATION OF THE PROJECT $\ldots \ldots \ldots \ldots \ldots \ldots \ldots \ldots \ldots . \ldots \ldots$

Evaluation of the Four-stage Elderly Evangelism Model ....... 131

Pastoral and Lay Visitation ................... 132

Friendship Evangelism ...................... 133

Competent Programs ........................ 135

Dynamic Worship .......................... 137

Recommendations .......................... 139

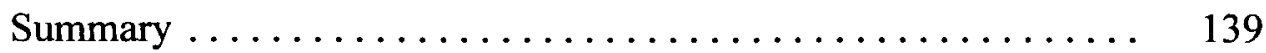

VII. SUMMARY AND CONCLUSIONS $\ldots \ldots \ldots \ldots \ldots \ldots \ldots \ldots .142$

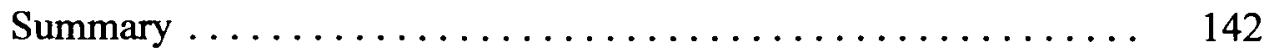

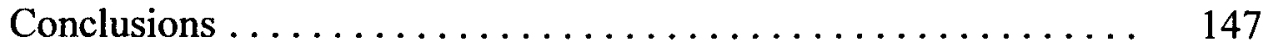

Observations ......................... 147

Appendix

CHURCH MEMBERS SURVEY $\ldots \ldots \ldots \ldots \ldots \ldots \ldots \ldots \ldots \ldots \ldots . \ldots \ldots$

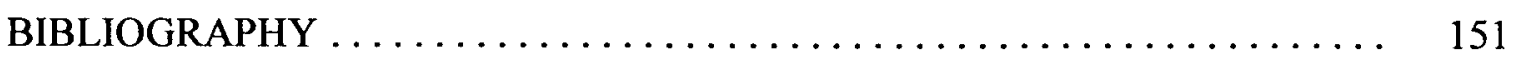

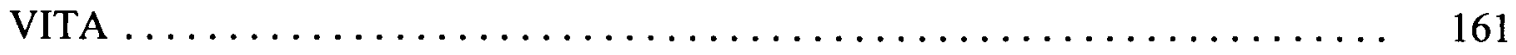




\section{LIST OF TABLES}

1. Data on Four Elderly Social Centers $\ldots \ldots \ldots \ldots \ldots \ldots \ldots \ldots \ldots . \ldots 6$

2. Distribution of Age Groups in Siu Sai Wan Center ............. 70

3. Household Composition of the Elderly $\ldots \ldots \ldots \ldots \ldots \ldots \ldots \ldots \ldots, 70$

4. Members' Involvement on Visitation and Phone Contact ........... 132

5. Members' Involvement in Friendship Evangelism............... 134

6. Church's Competent Programs...................... 136

7. Number of Evangelistic Meetings, Elderly Non-Adventist Guests Attendance and Total Attendance . . . . . . . . . . . . . . . . 137

8. Church's Worship................................ 138

9. Worship Attendance. .............................. 138

10. Number of Elderly Baptisms. . . . . . . . . . . . . . . . . . 141 


\section{LIST OF ABBREVIATIONS}

$\begin{array}{ll}\text { ASV } & \text { American Standard Version of the Bible } \\ \text { KJV } & \text { King James Version of the Bible } \\ \text { NAB } & \text { The New American Bible } \\ \text { NIDNTT } & \text { The New International Dictionary of New Testament Theology } \\ \text { NIV } & \text { New International Version of the Bible } \\ \text { NKJV } & \text { New King James Version of the Bible } \\ \text { NLT } & \text { New Living Translation of the Bible } \\ \text { NRSV } & \text { New Revised Standard Version of the Bible } \\ \text { SDABC } & \text { Seventh-day Adventist Bible Commentary } \\ \text { SDABD } & \text { Seventh-day Adventist Bible Dictionary } \\ \text { TDNT } & \text { Theological Dictionary of the New Testament } \\ \text { TEV } & \text { Today's English Version of the Bible or Good News Bible }\end{array}$




\section{ACKNOWLEDGMENTS}

The writing of a dissertation and the implementation of this project have been a long and tedious process. First of all, I praise God for leading and opening the way for me to participate in this D.Min. program. I was fortunate that all of my church members, my friends, and my family prayed for me along the way. They supported and encouraged me like Aaron lifting up Moses' hands to win the battle. To all of them I sincerely give my heartiest thanks.

Despite the limitation of space, I should particularly like to thank the following persons: Dr. Skip Bell for introducing this practical D.Min. program to me; Dr. Kidder, my adviser, guided me throughout this project; Dr. Kurt Johnson, my second reader, for his encouragement and careful reading; and Dr. James Zackrison for editing this project. Acknowledgement is also due to my friends Dr. Benjamin Giang, Pastor and Mrs. John Ash, Dr. David Hartman, and my best friend Tran Quoc Co; also my dear twelve young people in Siu Sai Wan Church who have helped implement this project. Permit me to insert a word of thanks to my parents, for whom most of the credit for this project goes, and especially to my dear husband Pastor Terry Tsui, for his support, patience, understanding, love, and prayers from beginning to end. 


\section{CHAPTER 1}

\section{INTRODUCTION}

\section{Statement of the Problem}

The number of senior citizens ${ }^{1}$ in Hong Kong is increasing, and is calculated to become a burden for the Government. By 2036, approximately one-fourth of the population of Hong Kong will fall into the elderly category, ${ }^{2}$ representing a challenge to the government as well as to the church.

The Hong Kong-Macao Conference of Seventh-day Adventists currently operates

four social centers ${ }^{3}$ for the elderly. There are over 2,000 residents, termed "members"4 in these facilities. Presently just over 100 are Seventh-day Adventists. Currently in Hong

${ }^{1}$ According to Hong Kong Government statistics, the senior citizens refer to those who are 65 or above.

${ }^{2}$ According to the Census and Statistics Department, the population of the elderly will increase from $12 \%$ in mid-2006 to $26 \%$ in mid-2036, representing 1 elderly for every 4 persons. By contrast, the ratio for youth who are 15 or below will go from $14 \%$ to $12 \%$. See "Hong Kong Population Projections 2007-2036," ed. Census and Statistics Department (The Government of Hong Kong Special Administrative Region, 2007), 5, http://www.censtatd.gov.hk/products_and_services/products/publications/statistical_repo rt/population_and_vital_events/index_cd_B1 12001503_dt_latest.jsp (accessed $26 \mathrm{July}$ 2009).

${ }^{3}$ Social Centers for the Elderly organize social and recreational activities for elders in the community and provide information regarding welfare services for the elders and referral to appropriate services.

"“Members" refer to the elderly members of the social centers. The criterion for hecoming a member is to he over sixtv vears of age. 
Kong there is no tested evangelistic strategy in place to reach this sector of the population.

Besides the rapid growth patterns of the elderly population in Hong Kong, the Hong Kong Government faces the challenge of limited finances and resources for the elderly. In addition, many elderly are illiterate and from the low to lower-middle classes of society. These factors make their lives dependent of someone other than themselves.

The traditional worldviews and religions of the elderly make it difficult for them to accept the gospel. The majority are ancestor worshippers, which represents a barrier to their becoming Christian. This situation is compounded by a long-running debate in Christian circles about whether ancestor worship should be considered idol worship or simply as a memorial service to a deceased forebearer.

Some believe that the contribution ${ }^{5}$ the elderly make to the church and society is minimal. The result is that this group tends to be neglected, with more emphasis given to youth activities. On the other hand, Win and Charles Arn suggest that the elderly are receptive to the gospel, ${ }^{6}$ but that there is a general lack of elderly evangelism due to:

5“"Contribution" is judged in terms of participation and helping in church activities, given the fact that many elderly in Hong Kong are illiterate. "Contribution" also refers to financial support.

${ }^{6}$ The Arns gave three reasons why the elderly are receptive to the gospel: (1) they are experiencing many changes in life, (2) they have an increased desire for meaningful relationships with others, and (3) they want (and need) to make a meaningful contribution to society. The Arns are right that people tend to be more receptive to the gospel during times of transition or changes in life. For the elderly, it may be the death of a spouse, a move to a retirement home, physical and financial problems, etc. Also, friendship evangelism would be more appealing to them because they are looking for meaningful relationships which would provide them with a sense of belonging and affirmation of their self-worth. See Win Arn and Charles Arn, Catch the Age Wave: A Handbook for Effective Ministry with Senior Adults (Kansas City, MO: Beacon Hill Press, 1999), 68-73. 
(1) lack of vision and knowledge of what can and should be done, (2) non-growth excuses, and (3) self-imposed ageism: the attitude of senior adults themselves based on a philosophy of "we have served; now we want to be served." Besides the work of the Arns, there is a scarcity of literature on evangelism of the elderly, indicative of the need for a strategic evangelistic outreach model for the elderly.

\section{Purpose of the Project}

The purpose of this project is to develop effective methods of evangelizing elderly members of Siu Sai Wan Social Center for the elderly of Hong Kong-Macao Conference of Seventh-day Adventists, and to lead them to accept Jesus Christ and be baptized. These methods are based on four biblical principles of evangelism and incorporated into a Four-stage Elderly Evangelism Model.

By using the principles of visitation evangelism, friendship evangelism, culturally-relevant competent programs, and dynamic worship, Siu Sai Wan Elderly Center was a place where the elderly receive spiritual guidance as well as social, physical, and material aid. I saw that when this system was put into practice, the Elderly Center was transformed and became a place where the elderly can learn the truth of the gospel, accept Jesus Christ, and become members of the Seventh-day Adventist church.

\section{Justification for the Project}

The first justification of this project is found in the mandate of the Great

${ }^{7}$ Arn and Arn, 53, 54. 
Commission in Matt 28:18-208 to: "go," "make disciples," "baptize," and "teach," and the Great Commandment to love God supremely and your neighbor as yourself in Matt 22:37-39. The Great Commission includes the challenge of the elderly people in the social center who are mostly, as noted, low to lower middle class, illiterate, and ancestor worshipers. To share the gospel with the elderly, the Great Commandment of love must be also in place. It represents the driving force "to go" and the attractive power to draw them to Jesus Christ.

Second, because (1) there is a scarcity of research done on elderly evangelism, (2) an accompanying dearth of literature on the topic, and (3) the elderly population of Hong Kong is notably increasing, a research study on how to evangelize the elderly will make a significant contribution to an increasingly important ministry of the church.

A third justification for this project is that it provided a strategy, termed a "Fourstage Elderly Evangelism Model," for reaching and leading elderly people to Christ. This evangelism strategy can also serve as a model for the other three Social Centers for the Elderly and for churches doing elderly evangelism in the Hong Kong-Macao Conference of Seventh-day Adventists.

A fourth justification is to provide a practical, personal approach to give the elderly in the latter stages of life the opportunity to accept Christ and be baptized. This is a particularly meaningful justification since this may well be their last and possibly only opportunity to learn about the love of Jesus and the plan of salvation.

A fifth justification is to train and mobilize the Siu Sai Wan church members to

\footnotetext{
${ }^{8}$ All biblical references are taken from the New International Version unless otherwise specified.
} 
reach the elderly. In the process of evangelization members learned how to respect, care for, and love the elderly, while at the same time meeting the needs of this socially vulnerable group. Additionally, they had the joy of seeing them baptized and the additional joy when Jesus comes again and says to them that when they did it for one of the least of these "brothers," they did it for Jesus Himself (Matt 25:40).

A sixth justification is that it helped the church membership to grow spiritually and numerically.

A seventh justification for this project is that it provided a model on how to evangelize the Chinese at large. This is because the elderly have inherited the largest portion of traditional Chinese culture. Successfully evangelizing the Chinese elderly opens the door to Chinese at large. This is particularly helpful for evangelizing the Chinese in countries where they are a minority group and still hold to very traditional Chinese culture.

\section{Definition of Terms}

Some of the key terms used in this paper are:

Ancestor Worship. Chinese culture has been deeply influenced by Confucianism and Taoism, two traditional Chinese religions. They believed their ancestor's spirits live on after death, so ancestor worship is considered to be a continual expression of filial piety. It is one of the most important institutions. Ancestor worship has three important meanings for the elderly:

1. Ancestor worship is a family religious activity; it is a continual relationship between the deceased and the living, and remembrance of their ancestors.

2. The departed ancestors need to be cared for; therefore, the male heir has to 
offer the deceased ancestor food and burn life-sized paper models of clothing, furniture, sedan chairs, horses, donkeys, cows, and servants to the ancestors.

3. The Chinese believe that their ancestors' spirits continue to exist, and have power over the living, whether to protect or bless them. Therefore, they have a duty to worship their ancestors by burning incense in front of their altars every day.

Elderly, Older Persons, Old People, Senior Adults, or Senior Citizens refer to those age 65 or over.

Elderly Member of the Social Center refers to those 60 years old or over.

Filial Piety refers to the "appropriate behavior and attitude of duty toward one's parents, the elderly within the family, and one's ancestors."9

Four-stage Elderly Evangelism Model is the four stages of a process, based on four biblical evangelism principles to evangelize the elderly: (1) From House to House; (2) From Confrontational Evangelism to Friendship Evangelism; (3) From Chinese Festivals to Celebration and Feast, and (4) From Worshipping Forefathers to Worshipping Heavenly Father. In Adventist language, they refer to visitation evangelism, friendship evangelism, culturally-relevant competent programs, and dynamic worship.

Friendship Evangelism means that wherever you are, whatever you are doing, you consciously work at building relationships that will open doors to lead people to the gospel. It is making friends with deep care and concern, in order to let them know about Jesus.

${ }^{9}$ Chi-keung Desmond Choi, "A Proposed Model of Christian Pastoral Care with the Chinese Elderly in Hong Kong" (Ph.D. dissertation, Southwestern Baptist Theological Seminary, 1999), 111. 
Gospel Opera Songs refer to those opera songs in traditional Cantonese tunes that all the elderly are familiar with. The lyrics have been changed to gospel wording. These songs appeal strongly to the elderly, and the messages of the gospel lyrics get across to their minds easier and in a more natural way.

Gospel Tea Party is a spiritual meeting for the elderly members of the social center. The contents include gospel opera songs, Bible messages, lucky draw, gifts, and various kinds of drinks substituted for tea.

Social Center for the Elderly refers to the centers that "organize social and recreational activities for senior citizens in the community and provide information regarding welfare services and referral to appropriate services for the elderly.,"10

Worldview refers to "the product of all the information, ideas, and experiences you absorb to form the values, morals, and beliefs that you process."

\section{Limitations of the Project}

The basic timeframe for this study was two years. This represents a limitation because some elderly are so rooted in the traditional Chinese thinking of ancestor worship that it takes a long time to change their traditional mindset.

As stated, many of them are illiterate. It takes a long time to educate them in the truth. Also, the elderly tend to forget easily. Bible study and worship sermons must be

\footnotetext{
10"Elderly Service in Hong Kong," The Hong Kong Council of Social Service, http://www.hkcss.org.hk/download/folder/el/el_eng.htm (accessed 22 July 2009).

${ }^{11}$ George Barna, Think Like Jesus: Make the Right Decision Every Time (Ventura, CA: Issachar Resources, 2003), 35.
} 
done in a very simple, easy to understand way using repetition and, as far as possible, visual aids.

Human resources are another limitation. The majority of the members of Siu Sai Wan Church are themselves elderly. Only a few can actually help in elderly evangelism. We relied on a group of young people to do the work and to implement the principles. This caused us to struggle with participation burnout.

Finally, the lack of resources is a limitation. While significant research has been done on church growth and evangelism, little has been written on elderly evangelism. Research has focused on general evangelization of people of all ages rather than the specific age group of the elderly. A literature search revealed only a single doctoral level research work done on senior adult evangelism. ${ }^{12}$ There is some literature on elderly pastoral care, but to the best of my knowledge the current project is the first undertaken on Chinese elderly evangelism.

${ }^{12}$ The key words in the search were "elderly, senior adults, old, and evangelism, etc." The only doctoral dissertation found at "Proquest Dissertations Online" on elderly evangelism was William Harold Day, Jr., "The Relationship of Selected Contextual and Institutional Factors to the Evangelism of Senior Adults in Churches of the Southern Baptist Convention" (Ph.D. dissertation, New Orleans Baptist Theological Seminary, 1999). However, this research has a different focus than my research objective on Chinese elderly evangelism principles. Other resources, such as Win and Charles Arn's Catch the Age Wave: A Handbook for Effective Ministry with Senior Adults provide some very general ideas and principles; George Barna's The Habits of Highly Effective Churches: Being Strategic in Your God-Given Ministry provides some general insights on effective methods among different age groups. Also, Gary McIntosh's One Size Doesn't Fit All and Three Generations: Riding the Waves of Change in Your Church; David Gallagher's Senior Adult Ministry in the 21st Century: Step-by Step Strategies for Reaching People Over 50; Richard Gentzler, Jr.'s Designing an Older Adult Ministry; and Desmond Choi's Ph.D dissertation, "A Proposed Model of Christian Pastoral Care with the Chinese Elderly in Hong Kong," all provide some good ideas about elderly ministry, but not much about elderly evangelism principles. 


\section{Delimitations of the Project}

I have chosen to delimit my study in several areas. First, I have served as pastor of the Siu Sai Wan Church of Seventh-day Adventists for fifteen years. It is definitely an advantage for me because I know the members of the church and of the center so well. Also, the years of experience working with the elderly have already made me aware of my attitudes and methods in elderly evangelism. Nevertheless, to replicate the results in other social centers or churches by using the same Four-stage Elderly Evangelism Model may produce different results.

Another delimitation has to do with the focus of the evangelism principles outlined in the Four-stage Elderly Evangelism Model, that is, (1) visitation evangelism, (2) friendship evangelism, (3) culturally-relevant competent programs, and (4) dynamic worship. While there may well be other effective spiritually focused methods and principles in elderly evangelism such as prayer ministry, this project is aimed at the "doing" facet of evangelism rather than the "being" aspect.

An additional delimitation is the implementation of this project in the setting of the social center for the elderly, which is relatively uncomplicated, since the target audience is a relatively "captive" audience. Moreover, the model is deliberately developed within the context of an Adventist church setting with the proposal that the tested model would be a resource for other Adventist churches and social centers.

\section{Description of Methodology}

It took more than two years to try out and implement the Four-stage Elderly Evangelism Model in Siu Sai Wan Social Center for the Elderly. The procedures are described below. 
First, I established the theological foundations for elderly evangelism, based on the Bible, the writings of Ellen G. White, and other apropos Christian literature. The foundations included the Great Commission (Matt 28:18-20) and the Great Commandment (Matt 22:37-40), the characteristics of the elderly, four notable elderly characters from the Bible, and the blessings for the elderly as described in the Bible. Also, three particular conversion stories of the elderly in the Bible: (1) Nebuchadnezzar, (2) Nicodemus, and (3) the 38-year cripple, were studied to discover some principles for elderly evangelism.

Second, the various evangelistic challenges were studied. These included the rapid growth of the elderly population in Hong Kong, challenges facing the elderly in Hong Kong society, and a study of the elderly worldview in the light of the concepts of filial piety and ancestor worship. Also, we studied the values and mindset of the elderly to be sure that our plan would be seeker-sensitive and culturally-relevant.

Third, a profile for Siu Sai Wan Social Center for the Elderly was done. This provided the background information of the center.

Fourth, I established the evangelism principles for elderly evangelism. These were incorporated into the Four-stage Elderly Evangelism Model. Using the model, I did four things: (1) led church members in visitation, (2) provided some simple training, (3) modeled for them how to do visitation evangelism and friendship evangelism, and (4) set the goals and strategies. The model is divided into two parts, the "going" and "coming" parts. The "going" part, in which we go out and reach the people, included visitation evangelism and friendship evangelism. The "coming" part, meaning that we encourage the people to come to us, was based on providing quality and culturally- 
relevant programs and worship events to attract them to join us. Through the aggressive visitation program, many elderly were invited to come to our programs and worship. In order to make the programs culturally relevant, we provided a gift at each meeting as a token of appreciation. The gifts were specially chosen to match the needs of those attending especially as it related to a current meaningful festival.

Fifth, we constantly reminded the church members of the importance of evangelizing the elderly. I and my husband, Terry, set the example by leading out in the entire project.

Sixth, I developed a survey questionnaire to measure the effectiveness of the model. The survey was conducted before and after the implementation of the evangelism model. Then, I evaluated the results of the two surveys. In addition to the subjective views of the church members on the effectiveness of the evangelism model, I provided some data/statistics which supplied us with some objective facts on how we were doing, and tested whether or not the Four-stage Elderly Evangelism Model was successfully implemented.

Last, I summarized the Four-stage Elderly Evangelism Model and drew some conclusions. 


\section{CHAPTER 2}

\section{THEOLOGICAL FOUNDATIONS FOR ELDERLY EVANGELISM}

This chapter explores the theological foundations for elderly evangelism. First, biblical perspectives on contextualized evangelism are established. Second, a study is made on the biblical view of the world and the two mandates in terms of the Great Commission and the Great Commandment. Third, it examines the blessings in the Bible, characteristics of the elderly, and four notable elderly characters in the Bible. Fourth, a study of three elderly conversions in the Bible is made: one from the Old Testament and two from the New Testament. Last, the writings of Ellen White are consulted, and reference is made to Christian literature for additional insights.

\section{Biblical Perspectives on Contextualized Evangelism}

The biblical perspectives on contextualized evangelism are based on certain basic theological presuppositions, on which our methodologies are based and developed. First of all, the presupposition is to accept the Bible as our only creed and its authority over all other religious sources (2 Pet 1:20, 21; 2 Tim 3:16, 17). In the Bible, one can learn about the existence of the Christian God (Deut 6:4; 1 Tim 1:17) and the Christian gospel is described in the exclusiveness of salvation through Christ (John 3:16; Acts 4:12).

Next, the presuppositions regarding the Christological truths are that "God the eternal Son became incarnate in Jesus Christ. Through Him all things were created, the 
character of God is revealed, the salvation of humanity is accomplished, and the world is judged. ... He became also truly man, He suffered and died voluntarily on the cross for our sins and in our place, was raised from the dead. ... He will come again in glory for the final deliverance of His people and the restoration of all things (John 1:1-3, 14; Col 1:15-19; John 10:30; 14:9; Rom 6:23; 2 Cor 5:17-19; John 5:22; Luke 1:35; Phil 2:5-11; Heb 2:9-18; 1 Cor 15:3, 4; Heb 8:1, 2; John 14:1-3)."1

Then, the presupposition that fallen angels (demons) are real, Satan, the chief of fallen angels, tempted Adam and Eve to sin. He is pictured as a roaring lion seeking to devour all people (1 Pet 5:8). But God's angels have more power than fallen angels, and Jesus' victory on the cross "gives us victory over the evil forces that still seek to control us"2 (Col 1:13, 14; Luke 10:17-20; 2 Pet 2:9).

\section{The Biblical View of the World and Its Implications for Elderly Evangelism}

\section{A Biblical View of the World}

Gottfried Oosterwal is right when he wrote, "Ever since Christ called His church into existence, Christians have been struggling with the problem of how to be in the world without being of the world." Further, Ellen White states, "So long as we are in the

\footnotetext{
1'"Fundamental Beliefs," Seventh-day Adventist Church, http://www.adventist.org/beliefs/ fundamental/index.html (accessed 13 April 2010).

${ }^{2}$ Ibid.

${ }^{3}$ Gottfried Oosterwal, The Christian in the World, Adult Sabbath School Lessons (Mountain View, CA: Pacific Press, July-September, 1982), 3.
} 
world, we must have to do with the things of the world."4 The biblical meaning of the term "world" includes people, such as families, language groups, races, societies, nations (Mark 16:15; Luke 2:1; John 6:33; Rom 1:8); the things with which people are involved, such as human work, cultures, and organizations (Matt 16:26). ${ }^{5}$

Our understanding of the world will shape our attitudes toward it. Psalms 24:1 tells that the environment and humanity both belong to God. It suggests the close tie between human beings and their surrounding. Oosterwal lists four points about this relationship: (1) human beings were made to glorify God (Isa 43:7; 1 Cor 6:19, 20); (2) they were made for each other: to love and to strengthen each other, to challenge and to complement each other (Luke 10:27; 1 John 4:7-12); (3) they were commissioned to be fruitful and to fill the earth (Gen 1:26-28); (4) God put them in charge of His world, as His stewards, to explore its riches and resources and to develop the world and to preserve it, under God. ${ }^{6}$

\section{The Church and Human Needs}

As Jesus was sending His twelve disciples, He said to them, "As you go, preach this message: 'The kingdom of heaven is near.' Heal the sick, raise the dead, cleanse those who have leprosy, drive out demons. Freely you have received, freely give" (Matt 10:7, 8). Here Christ commissioned them while they are preaching about the coming of

\footnotetext{
${ }^{4}$ Ellen G. White, Testimonies for the Church, 9 vols. (Mountain View, CA: Pacific Press, 1948), 5:459.

${ }^{5}$ Oosterwal, 15.

${ }^{6}$ Ibid., 14.
} 
the kingdom of God, they are also to do works of compassion - to heal the sick, to feed the hungry, to comfort the bereaved, to give new dignity to the poor and the social outcasts. Proclamation, as described by Oosterwal, "means nothing without works of compassion (1 Cor 13:1-3). The reverse is also true, however. Works of compassion, assistance in human needs, must be accompanied by the clear message of the kingdom of God."7 Proclamation and compassion are inextricably intertwined.

\section{Attitude Toward Those in Need- Compassion}

Our world is ill today. Millions of people are suffering from starvation, malnourishment, poverty, oppression, leaving their homes due to wars, political stress, and economic hardships. We have no mission of our own, we imitate and continue the mission of our Lord, that is "to preach good news to the poor. He has sent me to proclaim freedom for the prisoners and recovery of sight for the blind, to release the oppressed" (Luke 4:18).

Concern for the poor was commanded by the law of Moses (Exod 22:25-27; Deut 15:7, 8), proclaimed by the prophets (Isa 3:14, 15; Jer 5:26-29; Ezek 16:49), taught by Jesus Christ (Luke 4:18; 2 Cor 8:9), and practiced by the early church (Acts 2:45; $4: 32 ; 11: 27-30$; 1 Cor 16:1-3; Gal 2:10).

Our God is a compassionate God (Exod 22:27; Ps 116:5). Jesus was always moved by compassion, ${ }^{8}$ He set out to healed the sick (Matt 14:14), to feed the four

${ }^{7}$ Oosterwal, 14.

${ }^{8}$ Compassion (Greek, Splanchnizomai) means "have pity, show mercy, feel sympathy." It is often used of the attitudes of Jesus "towards the multitude and towards 
thousand (Matt 15:32; Mark 8:2), to restore the sight of two blind men (Matt 20:34), to heal the lepers (Mark 1:41), and to teach the crowd since they were like sheep without a shepherd (Mark 6:34), etc. He responded to need, whether physical or spiritual.

The New International Dictionary of New Testament Theology notes in the parables of Matt 18:23-35 (the unforgiving servant) and Luke 15:11-32 (the prodigal son), that "compassion" expresses the strongest feeling of a merciful (Matt 18:27) or loving (Luke 15:20) reaction which forms the turning point of the story. In the parable of Luke 10:30-37 (the good Samaritan), "compassion" (Luke 10:33) expresses the "attitude of complete willingness to use all means, time, strength, and life, for saving at the crucial moment."9

Jesus responded to those in need with both "compassion" and "action." To Him, "humanity and neighborliness are not qualities but action." 10 Jesus has made “compassion" His standard of judgment (Matt 25:31-46; 18:33; Ps 112:5). He wants His followers to follow His example. Ellen White wrote in Gospel Workers: "The tender sympathies of our Saviour were aroused for fallen and suffering humanity. If you would be His followers, you must cultivate compassion and sympathy."11

individual sufferers, Matt. 9:36; 14:14; 15:32; 18:27; 20:34; Mark 1:41; 6:34; 8:2; 9:22 (of the appeal of a father for a demon-possessed son); Luke 7:13; 10:33; of the father in the parable of the Prodigal Son, 15:20." See W. E. Vine, An Expository Dictionary of New Testament Words (Nashville, TN: Thomas Nelson, 1952), s.v. "Compassion."

${ }^{9}$ Hans-Helmut Esser, "Compassion," The New International Dictionary of New Testament Theology, 3 vols., ed. Colin Brown (Grand Rapids, MI: Zondervan Publishing House, 1986), 2:600.

${ }^{10}$ Ibid. 403.

${ }^{11}$ Ellen G. White, Gospel Workers (Washington, DC: Review \& Herald, 1948), 


\section{Attitude Toward Aliens and Refugees- Hospitality}

God is concerned about aliens and refugees, "He defends the cause of the fatherless and the widow, and loves the alien, giving him food and clothing. And you are to love those who are aliens, for you yourselves were aliens in Egypt" (Deut 10:18, 19). They are socially powerless and economically handicapped; thus, need extra care and love (Deut 12:12;14:29). The story of the Samaritan tells us, in this very sense, that they are our neighbors (Luke 10:25-37).

God gave Israel specific laws and social institutions to protect the aliens. They were entitled to the "second" harvest (Lev 19:10; 23:22); the tri-annual tithes (Deut $14: 28,29)$; shared in the produce of the sabbatical year (Lev 25:6).

Accepting strangers is (1) pleasing God, "Accept one another, then, just as Christ accepted you, in order to bring praise to God (Rom 15:7), (2) entertaining angels, "Do not forget to entertain strangers, for by so doing some people have entertained angels without knowing it (Heb 13:2), (3) a requirement of church leaders, "Now the overseer must be above reproach, the husband of but one wife, temperate, self-controlled, respectable, hospitable, able to teach" (1 Tim 3:2; also Titus 1:8), (4) a good deed, "And is well known for her good deeds, such as bringing up children, showing hospitality" (1 Tim 5:10), (5) extolled in the biblical stories (Job 31:32) and is a duty as a work of compassion, and (6) commended and received by Jesus, "I was a stranger and you welcomed me, ... but the righteous into eternal life" (Matt 25:35, 46, NRSV). 
Thus, hospitality is a hallmark of God's people, motivated by love ${ }^{12}$ and is effective in breaking barriers in evangelism. "Strangeness," Stahlin remarks, "produces mutual tension between natives and foreigners, but hospitality overcomes the tension and makes of the alien a friend."13

\section{Attitude to Loneliness-Fellowship}

Loneliness, as described by Oosterwal, is one of the greatest diseases of our time.

It is due to the collapse of the traditional family systems, development of a mass society in cities, loss of faith, and decline of religion of modern man. The symptoms of loneliness in modern society are many. Observers of modern society point to rapid increase of suicide, drug abuse, alcoholism, mental illnesses, stress, violence, and crime. ${ }^{14}$

Many people are crying deep down inside as did David, "Turn to me and be gracious to me, for I am lonely and afflicted. The troubles of my heart have multiplied; free me from my anguish. Look upon my affliction and my distress and take away all my sins" (Ps 25:16-18). They are longing for help, friendship, and fellowship. The church is

${ }^{12}$ Motives of hospitality are many, "While agápe (love) is the ultimate motive, there is also a charismatic motive-hospitality is a charism; an eschatological motiveChristians are strangers and pilgrims going through affliction; a metaphysical motivethe hope of entertaining angels unawares (Heb 13:2); and above all a missionary motive-aiding itinerant evangelists (cf. Matt 10:11 ff.; Acts 10:6, 18, 32; Phlm 22; 3 John 8), which in the case of genuine messengers plays a big part in the spread of the gospel and may lead to the baptism of whole families (cf. Acts 16:15, 33; Rom 16:4-5)." See G. Stahlin, "Xenia," Theological Dictionary of the New Testament, ed. Gerhard Kittel and Gerhard Friedrich, trans. Geoffrey William Bromiley (Grand Rapids, MI: Wm. B. Eerdmans, 1985), 663.

$$
\begin{aligned}
& { }^{13} \text { Ibid., } 662 . \\
& { }^{14} \text { Oosterwal, } 162 .
\end{aligned}
$$


in a position that can alleviate their loneliness by providing meaningful fellowship.

Oosterwal stresses the importance of visitation when providing fellowship, "No society can accomplish what the church could do if it would accept its mission of visiting the lonely in their affliction." 15

Fellowship, in Greek generally koinōnia, means "association," "communion," "participation," "sharing" (in something). It is a "mutual sharing in some blessing or experience.... Koinonia was used by the early church to described the act of sharing one's temporal blessings with fellow believers ( 2 Cor 8:4); as such, it may appropriately be translated "contribution" (Rom 15:26; 2 Cor 9:13, RSV). ${ }^{16}$

So, through meaningful fellowship, Christians can lead people to God as they first have fellowship with God. "We proclaim to you what we have seen and heard, so that you also may have fellowship with us. And our fellowship is with the Father and with His Son, Jesus Christ. ... But if we walk in the light, as He is in the light, we have fellowship with one another, and the blood of Jesus, His Son, purifies us from all sin" (1 John 1:3, 7).

Its Implications for Elderly Evangelism

God loves this world simply because He is love (1 John 4:8). He wants to reconcile with the fallen world through His son (2 Cor 5:19). Reconciliation means to bring back the new relationship of peace between God and humanity through forgiveness

${ }^{15}$ Oosterwal, 162.

${ }^{16}$ Seventh-day Adventist Bible Dictionary, ed. Siegfried H. Horn (Washington, DC: Review and Herald, 1960), s.v. "Fellowship." 
and cleansing of our sins (Rom 5:1, 8-11; 2 Cor 5:18, 19; Eph 2:12-18). In turn, He wants us to affirm the purpose for which He has put us on this world-to glorify Him. "Everyone who is called by my name, whom I created for my glory, whom I formed and made" (Isa 43:7).

We can "give Him glory" (Rev 14:6, 7) through sharing the everlasting gospelthis is the evangelistic mandate, and also through our good deeds, "In the same way, let your light shine before others, so that they may see your good works and give glory to your Father in heaven" (Matt 5:16, NRSV). This refers to the cultural mandate. ${ }^{17}$ Our understanding to this world of suffering, poverty, aliens, and loneliness shapes our attitudes toward them. In order to win them for Christ, we need to be compassionate, hospitable, and build our friendship and fellowship with them through visitation and time spent together.

This understanding of the world has an important implication for elderly evangelism. Particularly, when people are getting old and lonely, they need more help, care, love, and fellowship. In the Hong Kong setting, many elderly fall into the category of a social vulnerable group as many are illiterate, poor, and lonely. They particularly need our compassion, help, hospitality, friendship, fellowship, and visitation. These become the key words, values, and principles in forming the elderly evangelism model which will be further discussed in the chapter 4 . Also, the two mandates go side by side

\footnotetext{
${ }^{17}$ Peter Wagner states that holistic mission is made up of two mandates: the cultural mandate and the evangelistic mandate. The term "mandate" is used to indicate that it is mandatory, not optional. For the cultural mandate, he refers to the Great Commandment (Matt 22:39); and for the evangelistic mandate, the Great Commission (Matt 28:19). It is one mission in two parts; Christian social ministry and evangelism. See C. Peter Wagner, Strategies for Church Growth: Tools for Effective Mission and Evangelism (Ventura, CA: Regal Books, 1987), 99-101.
} 
in elderly evangelism. The cultural mandate is to meet their needs, thus, forming an entering wedge for the evangelistic mandate to reach their hearts; it is to help them receive the "blessings of the Lord" through our good deeds, and to accept the "Lord of blessings," Jesus Christ, through our words of preaching.

\section{The Two Mandates}

In the Old Testament, Israel "was commissioned to create a caring community that reflected the true God. They were placed at the crossroads of civilization, where all nations would come to them and learn about the true God." 18 This "caring community" was to manifest God's character to all nations, to glorify Him by "doing good works to others" (Matt 5:16), and drawing them to God. This is the concept of the "cultural mandate," 19 which is found in the "Great Commandment" that we love our neighbors as ourselves (Matt 22:39).

\footnotetext{
${ }^{18}$ Russell Burrill, Recovering an Adventist Approach to the Life and Mission of the Local Church (Fallbrook, CA: Hart Research Center, 1998), 10, italics added.

${ }^{19}$ Peter Wagner describes three aspects of the cultural mandate that would furnish our understanding in the mission of the church. They are: its origin, its demands, and its scope. First, it has its origin in God. Before the fall, God put Adam and Eve in charge of the fish, the birds, and all the wild animals (Gen 1:26, 28). Robert Webber calls it "delegated sovereignty" over God's earthly creation. They were to treat creation as God Himself would treat it. Second, God expects and demands of those to whom He has entrusted all His goodness. For instance, John the Baptist said to those who had affluence that they should share with the less fortunate with their tunics and food, should not overcharge and accuse people falsely (Luke 3:11-14). Third, the cultural mandate is in effect until Jesus returns. Christians should be concerned with social problems and social injustices. They should contribute in some ways to the effective fulfillment of the cultural mandate and must seek to spread its righteousness in the midst of the unrighteous world. See C. Peter Wagner, Church Growth and the Whole Gospel: A Biblical Mandate (San Francisco: Harper \& Row, 1981), 12-14.

Many elderly in Hong Kong are considered to be in the social vulnerable group, as they are illiterate, poor, and sick. Some are lonely, living alone, and without many
} 
In the New Testament, "in contrast to all of the nations coming to Israel, Christ commissioned the new Israel to go to the nations, ${ }^{, 20}$ to seek and find lost men and women and to bring them into fellowship with God. This is the concept of the evangelistic mandate found in Jesus' Great Commission in Matt 28:18-20.

The Great Commission states our duty, but must always be accompanied by love. Ellen White writes, "Duty has a twin sister, love."21 On the other hand, the Great Commission also has a twin sister-the Great Commandment. Mark Finley explains the relationship between the two: "Love without action or duty is mere sentimentalism. Duty without love is drudgery. It is rigid legalism. The love of Christ overflowing from our hearts reaches out in kind acts to people around us. Our greatest joy comes from blessing others. $^{, 22}$

\section{The Great Commission}

Before Jesus ascended to heaven, He gave His Great Commission to His disciples, "Then Jesus came to them and said, 'All authority in heaven and on earth has been given to me. Therefore go and make disciples of all nations, baptizing them in the name of the

friends. So, the cultural mandate is particularly important to elderly evangelism in the Hong Kong setting. They need more than the gospel, they need friendship, care, and love, and their needs met. For the effectiveness of elderly evangelism, the cultural mandate should go along with the evangelistic mandate, as Billy Graham describes the teaching of Jesus, to take regeneration in one hand and a cup of cold water in the other.

${ }^{20}$ Burrill, 10.

${ }^{21}$ White, Testimonies for the Church, 4:62.

${ }^{22}$ Mark Finley, Solid Ground: Daily Devotional for Adults (Hagerstown, MD: Review and Herald, 2003), 183. 
Father and of the Son and of the Holy Spirit, and teaching them to obey everything I have commanded you. And surely I am with you always, to the very end of the age'" (Matt 28:18-20).

The flying angel in the book of Revelation describes the work of His followers before Jesus' second coming, "Then I saw another angel flying in midair, and he had the eternal gospel to proclaim to those who live on the earth - to every nation, tribe, language and people" (Rev 14:6).

These passages do not specify a particular age group of people to be reached, because they include all age groups, "God's mission is to save the entire race of lost earth's children." ${ }^{, 23}$ Isaiah mentions that there will be old people in the new earth; "He who dies at a hundred will be thought a mere youth" (Isa 65:20). Zechariah also mentions the same, "This is what the LORD Almighty says: 'Once again men and women of ripe old age will sit in the streets of Jerusalem, each with cane in hand because of his age"" (Zech 8:4). Jesus Himself evangelized an elderly man, Nicodemus (John 3:1-15). Thus, the Great Commission mandate includes elderly evangelism. The driving force behind the Great Commission itself is commitment. ${ }^{24}$ As Rick Warren states it well, "While we wait

${ }^{23}$ Dwight K. Nelson, Pursuing the Passion of Jesus: How "Loving the Least" Helps You Fulfill God's Purpose for Your Life (Nampa, ID: Pacific Press, 2005), 17.

${ }^{24}$ Ellen White confirms the importance of commitment in God's work, "Those who labor for souls must attain to a deeper, fuller, clearer knowledge of God than can be gained by ordinary effort. They must throw all their energies into the work of the Master." Ellen G. White, The Acts of the Apostles (Mountain View, CA: Pacific Press, 1911), 205. 
for God to work for us, God is waiting to work through us!"25 This is commitment;

without it, nothing will happen—-the Great Commission demands a "Great Commitment."

\section{The Great Commandment}

Jesus was once tested by an expert of the law. He was asked which was the great commandment in the law. Jesus replied, "You shall love the Lord your God with all your heart, with all your soul, and with all your mind. This is the first and great commandment. And the second is like it: You shall love your neighbor as yourself" (Matt 22:37-41, NKJV). The basis of the great commandment is to love God and our neighbors. Jesus widens the definition of neighbor "to include all who are in need of help (see Luke 10:29-37). ${ }^{.26}$ Wagner explains that Christians possess an unlimited capacity for latent love, that is "a feeling of closeness and commonality with all other Christian and, indeed, all fellow human beings in the world. The feeling translates into a concern and compassion for needy people everywhere in obedience to the Great Commandment that we should love our neighbor as ourselves (Matt 22:39).,27 This is the essence of Christianity as expressed in encouraging words, kind deeds, and caring actions. Love always reveals itself in action.

Win Arn's exhaustive study confirms that "great churches are built on love-for

${ }^{25}$ Rick Warren, The Purpose Driven Church: Growth without Compromising Your Message \& Mission (Grand Rapids, MI: Zondervan, 1995), 60.

26" Matthew," The Seventh-day Adventist Bible Commentary (SDABC), ed. Francis D. Nichol (Washington, DC: Review and Herald, 1978), 5:484.

${ }^{27} \mathrm{C}$. Peter Wagner, Our Kind of People: The Ethical Dimensions of Church Growth in America (Atlanta, GA: John Knox Press, 1979), 156. 
God, for each other, and for unbelievers." ${ }^{28}$ Rick Warren describes love as a powerful magnet that draws people, "a lack of love drives people away." 29

The other driving force in fulfilling the Great Commission is Great Compassion. High technology alone is not enough to advance our message, we also need high-touch ministry. Rick Warren observes, "Our world is filled with lonely people who are starving for the affirmation of a loving touch. ${ }^{, 30}$ The Great Commission will be fulfilled with a greater impact if it is accompanied by Great Compassion.

\section{Benevolent Work and Blessings}

Before Jesus returned to heaven, He left the Great Commission for His disciples. When He returns He will ask what His people have done for Him, especially for "the least brethren." For I was hungry and you gave me something to eat, I was thirsty and you gave me something to drink, I was a stranger and you invited me in, I needed clothes and you clothed me, I was sick and you looked after me, I was in prison and you came to visit me. . I tell you the truth, whatever you did for one of the least of these brothers of mine, you did for me" (Matt 25:35, 36, 40).

This is the "well-done job" demanded by Jesus. This benevolent work is in the sense of fulfilling His Great Commission by service and compassion. This is particularly important in elderly ministry. While some elderly are well off, many are sick, in need, poor, and lonely and they need someone to care for them. They are in the so-called

${ }^{28}$ Arn and Arn, Catch the Age Wave, quoted in Warren, 210.

${ }^{29}$ Ibid.

${ }^{30}$ Ibid., 214. 
"social vulnerable group" that need both help and the gospel in their latter stages of life.

A parallel passage is found in Isa 58:7-10, which Ellen White terms the "highest important work." "I1 "Is it not to share your food with the hungry and to provide the poor wanderer with shelter - when you see the naked, to clothe him, and not turn away from your own flesh and blood?" (Isa 58:7). When we visit the sick, feed the hungry, meet the suffering souls, help the needy, we are "working in lines of Christ's ministry. The Master's holy work was a benevolent work."32

God knows as we do that in this benevolent work we will face challenges, so a three-fold blessing is attached to this command: (1) God renews our physical strength, "Then your light will break forth like the dawn, and your healing will quickly appear" (Isa 58:8a, italics added); (2) God builds a fortification around us, "Then your righteousness will go before you, and the glory of the Lord will be your rear guard" (Isa 58:8b, italics added); (3) God will answer our prayers, "Then you will call, and the Lord will answer; you will cry for help, and he will say: Here am I" (Isa 58:9, italics added). ${ }^{33}$ This three-fold promise accompanies those who are engaged in the work of mercy and love.

${ }^{31}$ White, Testimonies for the Church, 8:159. 29.

${ }^{32}$ Ellen G. White, Welfare Ministry (Washington, DC: Review and Herald, 1970), ${ }^{33}$ Ibid., 31 . 


\section{Blessings in the Bible}

\section{Biblical Meaning of Blessing}

"Bless," in the verb form, is generally Hebrew barak; Greek eulogeō; "blessed," generally Hebrew 'ashrê, barûk; Greek makarios, eulogēmenos, eulogētos. "Blessing." in the noun form, is Hebrew berakah; Greek eulogia. ${ }^{36}$

"Barak" is expressed in various shades of meaning. Vine notes that it first occurs in Gen 1:22 (KJV), God "blessed" the creatures in the sea and air, saying "Be fruitful and multiply," then the same blessing repeated upon man (Gen 1:28). After creation, God blessed the day Sabbath (Gen 2:3). He sustains His work by sending showers of blessing (Ezek 34:26), the whole creation depends upon divine blessing for its continued existence and function (Ps 104:27-30). ${ }^{37}$ Indeed, "God's blessing of a person means that God bestows good gifts upon him." ${ }^{38}$

34، "Barak" has 330 occurrences, is translated in KJV "bless" 302 times, "salute" five times, "curse" four times, "blaspheme" twice, "blessing" twice, "praised" twice, "kneel down" twice, "congratulate" once, "kneel" once, "make to kneel" once, and translated miscellaneously eight times. See James Strong, The Exhaustive Concordance of the Bible: Showing Every Word of the Text of the Common English Version of the Canonical Books, and Every Occurrence of Each Word in Regular Order (Ontario: Woodside Bible Fellowship, 1996), s.v. "Barak." Also, "Eulogeō" literally means "to speak well," it has the same meaning as barak in the NT. See $S D A B D$, s.v. "Bless."

35،'Ashrê" means "happy," basically it connotes the state of "prosperity" or "happiness" that comes when a superior bestows his favor (blessing) on one. See Vine, s.v. "Blessed."

36"Blessing" means an advantage or benefit, generally such as conferred by God or Christ (Gen 39:5; Deut 28:8). See $S D A B D$, s.v. "Blessing."

${ }^{37}$ Vine, s.v. "Blessing." Also, H. W. Beyer, "Eulogeo," TDNT, ed. Gerhard Kittel and Gerhard Friedrich, trans. Geoffrey William Bromiley (Grand Rapids, MI: Wm. B. Eerdmans, 1985), 275.

${ }^{38}$ SDABD, s.v. "Bless." 
The TDNT notes that specific blessings are related to salvation history (Gen 17:7, 8; 26:3), this is a spiritual blessing (Eph 1:3) which means eternal joy (Matt 25:34), and was promised to Abraham, his seed and those who have faith in God (Gal 3:7-9). ${ }^{39}$

In response to God's blessing, the SDA Bible Dictionary notes that in the OT "men are frequently mentioned as blessing God, which means that they acknowledged God as the bestower of spiritual and material prosperity (Ps 63:4; 103:1-5). ${ }^{, 40}$ When a "blessing" was directed to God, it was a word of praise and thanksgiving (Gen 14:20; Neh 9:5). The NIDNTT adds, "Praise be to the Lord" (Ps 28:6; 31:21; 66:20; 68:19; $119: 12 ; 124: 6$; etc.) is a response to the blessing of God at the close of worship. ${ }^{41}$ "Blessing" can also be used to express "a wish" that the other will be endowed with good gifts (Josh 14:13; 1 Sam 2:20). The blessing might also be presented more concretely in the form of "a gift" as a token of affection or good will (Gen 33:11; $2 \mathrm{Kgs}$ $5: 15) ;{ }^{42}$ or used as a common form of "greeting," "Blessed are you of the LORD!" (1 Sam

${ }^{39}$ Beyer, 275, 276.

${ }^{40} S D A B D$, s.v. "Bless."

${ }^{41}$ “"The blessing was bestowed at the close of worship on the members of the cultic community as they returned to their houses, that it might be realized in their daily lives (cf. the Pss. of blessing: 65; 115:12-15; 128; 129:8; 132, etc.). The community responded to the blessing that it had received by blessing Yahweh in their turn, in the cry of adoration, 'Praised be Yahweh." See Hans-Georg Link, "Blessing," The New International Dictionary of New Testament Theology (NIDNTT), 3 vols., ed. Colin Brown (Grand Rapids, MI: Zondervan Publishing House, 1986), 1:210.

${ }^{42}$ "The connection between blessing and gifts (cf. Gen 33:11) is shown especially in 2 Cor 9:5f. Paul calls the collection which he has been making for the community at Jerusalem a eulogia. The context shows that eulogia means a generous gift (as opposed to pleonexia, stinginess)." See Hans-Helmut Esser, "Blessing, Blessed, Happy," NIDNTT, 3 vols., ed. Colin Brown (Grand Rapids, MI: Zondervan Publishing House, 1986), 1:205215. Also, $S D A B D$, s.v. "Bless." 
15:13, NKJV), also "Saul went out to meet [Samuel], that he might salute him" (1 Sam 13:10, KJV; "greet," NASB and NIV). ${ }^{43}$

\section{Who Can Receive the Blessing}

Many of God's blessings are conditional upon human being obedience and cooperation. ${ }^{44}$ They become blessings if the commandments are kept (Deut 28:1), or cursing in the opposite (Deut 28:15). The Israelites had to choose (Deut 30:19) between the blessing (Deut 28:1-14) and the curse (Deut 28:15-68).

Also, the righteous who trust in God and do His will find blessing, but sinners cursing: "This is what the LORD says: "Cursed is the one who trusts in man, who depends on flesh for his strength and whose heart turns away from the LORD'... 'But blessed is the man who trusts in the LORD, whose confidence is in him"' (Jer 17:5, 7). The Psalms pronounce him blessed who trusts in God, "Blessed are those who put their trust in Him" (Ps 2:12; 34:8; 84:12, NKJV).

Blessings for the Elderly

According to Rachel Dulin, there is a mix of blessings for the elderly including: (1) long duration of life (Gen 25:7, 8; 35:28; Job 42:16), (2) lack of infirmity (Deut 34:7; Josh 14:11), (3) presence of children (Prov 17:6; Job 42:13-16), (4) economic success (Job 42:10-12), and (5) accord of respect (1 Chr 29:28). ${ }^{45}$ These blessings prove to be

${ }^{43}$ Vine, s.v. "Blessing."

${ }^{44} S D A B D$, s.v. "Bless."

${ }^{45}$ Rachel Zohar Dulin, “Old Age in the Hebrew Scriptures: A Phenomenological Study" (Ph.D. dissertation, Northwestern University, 1982), 96-101. 
important concepts in appealing to the Chinese mind. ${ }^{46}$

In addition to the five blessings noted above, I would add three more:

6. A fruitful old age. Some elderly think they become useless when they get old, but the Bible says, "They will still bear fruit in old age, they will stay fresh and green, proclaiming, the Lord is upright" (Ps 92:14,15). The old age of the righteous that is "happy and productive proves the faithfulness of God, and shows that He keeps His promises. ${ }^{, 47}$

7. God sustains the elderly, "Even to your old age and gray hairs I am he, I am he who will sustain you. I have made you and I will carry you; I will sustain you and I will rescue you" (Isa 46:4).

8. In blessings upon their descendents, David says, "I have been young, and now am old; Yet I have not seen the righteous forsaken, Nor his descendants begging bread" (Ps 37:25, NKJV). David saw that the elderly were blessed from their youth through their old age, and the blessings continued to their descendents. This is a powerful promise and blessing of God, especially when addressing the issue of ancestor worship. These

\footnotetext{
${ }^{46}$ The first four blessings are always mentioned during the Chinese New Year. The Chinese put the "Fai Chun," meaning lucky messages, usually in four characters, on the walls or doors, and greet people during the Chinese New Year with those messages, saying things like, 長命百歲, wishing them to live up to a hundred years of age (the first blessing); 身壮力健, be healthy and vigorous all year (the second blessing); 兒孫滿堂, children filling the house (the third blessing), the Chinese population proves this how important this is to the traditional Chinese minds; and 金玉滿堂, treasures filling the home (the fourth blessing). Even the fifth one is not usually mentioned in the Chinese New Year, but I am sure it is well liked by the Chinese.

47،"Psalms," SDABC, ed. Francis D. Nichol (Washington, DC: Review and Herald, 1978), 3:845, 846.
} 
blessings from the living heavenly Father are more valid than those from their deceased forefathers.

\section{Application of Blessings in Elderly Evangelism}

Blessings for the elderly can be a good message in elderly evangelism. ${ }^{48}$ Sharing the blessings for the elderly from the Bible will draw them to the Lord of blessings.

The Bible "blesses" both those who give the blessing and those who receive the blessing. Paul says, "It is more blessed to give than to receive" (Acts 20:35). In the OT, God made Abraham to be "blessing" to all nations (Gen 12:3); in the NT, Jesus made His twelve disciples to be "bearers of blessing" (Matt 10:1-16). ${ }^{49}$ Today, God wants "every nation, tribe, language and people" (Rev 14:6) to be blessed through the "bearers of blessing."

The idea of being "bearers of blessing" greatly motivates people in elderly evangelism. They can bless the elderly by sharing the blessings for the elderly as mentioned in the Bible, by inviting the elderly to come to worship on the blessed day Sabbath to receive the Aaronic 3-fold blessing. ${ }^{50}$ As "blessing" also refers to greeting and

${ }^{48} \mathrm{Blessing}$ is a very important concept and very appealing to the Chinese mindset of the elderly. During the Chinese New Year people like to put a red paper with a character of "blessings" on the door. It means that blessing comes to their home.

${ }^{49}$ In Jesus' commissioning of the twelve (Matt 10:1-16), NIDNTT notes the disciples are sent out as "evangelists" and "bearers of blessing" to greet houses (Matt 10:12), which refers to the "greeting of blessing (cf. v. 13 eirēnēe, Heb. šālômh, wellbeing)." See Link, 1:205-215.

${ }^{50}$ Numbers 6:24-26 records the wording of the priestly Aaronic 3-fold blessing to be pronounced at the end of every act of worship: "The LORD bless you and keep you; the LORD make his face shine upon you and be gracious to you; the LORD turn his face toward you and give you peace." The content of the 3 -fold blessing is protection, grace, 
gifts, by providing warm greetings and meaningful gifts to the elderly in worship they can truly be blessed.

\section{Elderly Characteristics and Characters}

In this section, a study is presented regarding the characteristics of the elderly as seen in Scripture to give us insight regarding our attitudes toward implementing them in elderly evangelism. Then, a study is included on four notable elderly characters in the Bible who demonstrated trust in God. These will serve as examples to do the same in elderly evangelism.

\section{The Characteristics of Elderly}

Some important principles of how to treat the elderly are derived from a study of the issue in both the OT and the NT. These principles provide us with some insights regarding evangelistic outreach.

\section{Elderly Need Respect}

It is no secret that the "elderly need respect." ${ }^{.51} \mathrm{We}$ will win the hearts of the elderly by rightly respecting them. Desmond Choi, in his study of pastoral care of the

and most comprehensively—well-being (peace). See Esser, "Blessing, Blessed, Happy," $1: 210$.

${ }^{51}$ 林志華, 敬拜上帝 (Worshipping God) (上海: 中國基督教兩會, 2005), 119. Also, "the word 'respect' comes from the Latin word 'respectus,' which translated literally means a looking back or to look back. ... Respect for the individual leads to tactfulness and adaptability." See Bob Johnson, You Can Witness: Yes-Even You (Lincoln, NE: AdventSource, 1995), 72. 
elderly, finds, "Levitical law demanded respect and honor for the older members." ${ }^{.52}$ In fact, this attitude toward the elderly is a command regardless of their wisdom, position, or wealth, "Rise in the presence of the aged, show respect for the elderly and revere your God" (Lev 19:32). John Hartley explains that the aged are to be highly honored (Prov $16: 31 ; 20: 29)$ as they have the wisdom of much experience; when showing proper honor to the aged, it is actually "an expression of one's fear of God."

Commentary concurs that this command amplifies the fifth commandment. Reverence and respect are fundamental virtues." ${ }^{.54}$ Conversely, Choi notes that "the lack of respect for the elderly exemplified a chaotic and ruthless society (Deut 28:49, 50; Isa 3:5)."

When people respect the elderly from the bottom of their hearts they will find ways to reach their hearts. Further, Choi adds, “The elderly's acceptance and honor in their communities is a sign of God's blessing (Isa 65:19-20; Zech 8:4). In addition, respect for age also brings blessing to the community." ${ }^{, 56}$ So, respecting the elderly becomes a double blessing, first to the elderly themselves and then to the community at large. A church is regarded as a spiritual community and will also benefit from this wonderful blessing from God by respecting the elderly in its ministry.

${ }^{52}$ Choi, 74.

${ }^{53}$ John E. Hartley, Leviticus, Word Biblical Commentary, vol. 4, ed. David A. Hubbard; Glenn W. Barker (Waco, TX: Word Books, 1998), 322.

54،"Leviticus," The Seventh-day Adventist Bible Commentary, ed. Francis D. Nichol (Washington, DC: Review and Herald, 1978), 1:792.

${ }^{55}$ Choi, 74, 75. Also, "Irreverence, disrespect, and lack of serious thought have ever been besetting sins. See "Leviticus," 1:792.

${ }^{56}$ Ibid., 74. 


\section{Elderly Need Submission from the Young}

Peter admonishes young people, "Be submissive to those who are older" (1 Pet 5:5). Submit, (Greek hupotassō), means "to submit oneself," "to be in subjection," "to obey. $"$ "It is "a voluntary attitude of giving in, cooperating, assuming responsibility, and carrying a burden. ${ }^{\prime 58}$ Here, Peter advises the younger members of the various congregations to respect the experience and judgment of the older because they are "mature in years and experience and to heed their counsel." $" 59$

Submission means to honor their experiences in life. Their failures and successes will help pastors advance and provide counsel in life. A Chinese saying conveys the same concept: "They eat more salt than we eat rice; they walk more on bridges than we walk on roads."

\section{Elderly Need Exhortation}

Paul instructs Timothy regarding our attitudes when correcting the elderly, "Do not rebuke an older man harshly, but exhort him as if he were your father" (1 Tim 5:1). Exhort (Greek, parakaleo, verb; paraklesis, noun) denotes “'to call to one's side,' hence,

57"Romans," The Seventh-day Adventist Bible Commentary, ed. Francis D. Nichol (Washington, DC: Review and Herald, 1978), 6:626.

${ }^{58}$ See Strong, s.v. "Hupotasso." The word has 40 occurrences; KJV translates as "put under" six times, "be subject unto" six times, "be subject to" five times, "submit (one's) self unto" five times, "submit (one's) self to" three times, "be in subjection unto" twice, "put in subjection under" once, and translated miscellaneously 12 times.

${ }^{59}$ Peter here probably refers the "older" to "age rather than to office (cf. 1 Tim $5: 1,17)$, though Peter's injunction would, of course, apply with special force to official "elders." See "1 Peter," The Seventh-day Adventist Bible Commentary, ed. Francis D. Nichol (Washington, DC: Review and Herald, 1978), 7:586. 
'to call to one's aid.' It is used for every kind of calling to a person which is meant to produce a particular effect, hence, with various meanings, such as 'comfort, exhort, desire, call for,,$" 60$

Exhortation means no discourtesy by the younger to those who are older, it also means "never severely chide"6l the old people, and "not with harsh, disrespectful words but in positive ways." ${ }^{\prime 62}$ The TDNT adds that "accompanying words show that the admonition is not sharp, polemical, or critical, even though it is urgent and serious," but the admonition is "in Christ" or "by His name" or "by His meekness and gentleness" or "by the mercy of God" (cf. Phil 2:1; 1 Cor 1:10; 2 Cor 10:1; Rom 12:1). ${ }^{63}$ Hartley explains further, "This exhortation is grounded on the greatest expression of love." The main use of parakaleo and paraklesis in the NT is specifically asking for: (1) Help, when people turn to Jesus for help (Matt 8:5; Luke 7:4; Mark 5:18; 6:56; 1:40; 8:22); (2) exhorting, used both for missionary proclamation (2 Cor 5:20; Acts 2:40; Luke 3:18), and pastoral admonition (Heb 13:22; 1 Pet 5:12; Jude 3; Phil 2:1; Rom 12:1); and (3) comforting, denotes both divine comfort in present and future salvation (2 Cor 1:3, 4;

${ }^{60}$ Vine, s.v. "Beseech." Strong notes "Parakaleo" has 109 occurrences; KJV translates as "beseech" 43 times, "comfort" 23 times, and "exhort" 21 times, etc. See Strong, "Parakaleo."

61“1 Timothy," The Seventh-day Adventist Bible Commentary, ed. Francis D. Nichol (Washington, DC: Review and Herald, 1978), 7:309.

${ }^{62}$ Stephen Sapp, Full of Years: Aging and the Elderly in the Bible and Today (Nashville, TN: Abington Press, 1987), 119.

${ }^{63}$ O. Schmitz, "Parakaleo," Theological Dictionary of the New Testament, ed. Gerhard Kittel and Gerhard Friedrich, trans. Geoffrey William Bromiley (Grand Rapids, MI: Wm. B. Eerdmans, 1985), 781.

${ }^{64}$ Hartley, 299. 
2 Thess 2:16; Rom 15:4; Heb 6:18; 12:5; Rom 15:4, 5), and human comfort (2 Cor 7:6; Col 2:2; 4:8; Phlm 7; 1 Thess 3:7). ${ }^{65}$

Barnabas is known as "the son of encouragement (paraklesis)" (Acts 4:36). The Bible records that he won many people to Christ: "When he came and saw the grace of God, he rejoiced, and he exhorted them all to remain faithful to the Lord with steadfast devotion; for he was a good man, full of the Holy Spirit and of faith. And a great many people were brought to the Lord" (Acts 11:23, 24). The SDA Bible Commentary explains, "The approval of the church in Jerusalem [Acts 11:22] on what was being done, as expressed in the joy and encouragement of Barnabas, 'the son of exhortation,' would increase the zeal of these earnest workers for Christ. ${ }^{~} 66$ When the zeal of church members increased, the result would be many people brought to the Lord. Thus, encouragement (or exhortation) has a part in increasing the zeal of the workers.

It can also be true that "exhortation (parakaleo)" has a part in elderly evangelism. Paul tells Timothy to "exhort the elderly" as his father (1 Tim 5:1). Elderly are experienced in life and feel strongly about their dignity. When treating them in a gentle, careful, and respectful manner as parents, helping and comforting (parakaleo) them in their afflictions, then their hearts can easily be open for our exhortation (parakaleo) in the present and future salvation.

${ }^{65}$ Schmitz, 778-782.

66“"Acts," The Seventh-day Adventist Bible Commentary, ed. Francis D. Nichol (Washington, DC: Review and Herald, 1978), 6:265, italics added. 


\section{Elderly Need Love}

The basic attitude toward the elderly is to respect them. This attitude "springs out of a Christian demand to love others (John 15:12)"67 and the theme "of respect for age in Scripture is seen mainly in terms of respect for parents (Exod 20:12; Lev 19:3; Deut 5:16). ${ }^{.68}$ In a similar way, when the Bible tells all to love their parents (Mark 7:10; Exod 20:12), it implies love for the elderly. Freeman Sleeper's description of three ethical demands of love from the Galatians passage helps to perceive how to treat the elderly with love. They are characterized by: "service" which demands self-giving (Gal 5:13); "support" which demands understanding (Gal 5:14), and "sharing" which demands accepting what others have to offer and giving to them (Gal 6:2). ${ }^{69}$

When people demonstrate Christian love that identifies with the hurts, the values, the hopes, and the needs and show respect, love, and sympathy to them, and treat them like parents or old friends, the elderly will open their hearts and talk to the people in the church as their friends — even as best friends.

\section{Four Notable Elderly Characters in the Bible}

Elderly like to tell and listen to stories, especially stories about the elderly. Thus, telling the stories of some notable elderly characters in the Bible will exert a positive influence on the elderly, and will appeal to them to follow and trust the same God as

${ }^{67}$ Choi, 78.

${ }^{68}$ Ibid., 75.

${ }^{69} \mathrm{C}$. Freeman Sleeper, Black Power and Christian Responsibility: Some Biblical Foundations for Social Ethics (Nashville, TN: Abingdon Press, 1969), 106-108. 
these characters did. This is important for elderly evangelism. Below are four examples of notable elderly characters.

\section{Abraham-A Trusting Hero}

Abraham is noted for his great faith and is called the "father of the faithful" (Gal $3: 7) .{ }^{70}$ However, he at first lacked faith. For instance, he once presented his wife as his sister (Gen 12:10-17) apparently to save his life, and he married Hagar in order to bear children (Gen 16:1-4). When he was one hundred years old, God tested his faith by asking him to offer his only son by Sarah as a sacrifice (Gen 22:2; Heb 11:17). He obeyed and as a result is called the father of the faithful.

Abraham set an example of trust for the elderly. Some are filled with "self confidence and self sufficiency., ${ }^{71}$ Sharing with them the story of a person who relied on his own way first, and but subsequently demonstrated faith in God and became a blessing for all nations (Gen 22:18) will greatly encourage the elderly.

\section{Daniel-A Prayerful Hero}

Daniel is noted for his prayers. They saved he himself, his friends, and the Babylonian wise men (Dan 2:18; 6:10,13). A second category of elderly are the "stable and satisfied type." They think stability is more important than anything else and do not

70، God had called Abraham to be the father of the faithful, and his life was to stand as an example of faith to succeeding generations." See Ellen G. White, Patriarchs and Prophets (Mountain View, CA: Pacific Press, 1958), 147.

${ }^{71}$ According to Tam, there are four kinds of elderly: (1) self-confident and sufficient; (2) stable and satisfied; (3) negative and pessimistic, and (4) low self-esteem. See Stephen Tam, 老賞益壯一長者生命成長路 (Aging with Vitality: A Path for Growth) (Hong Kong: Renewal Resourece (H.K.), 2000), 110, 111. 
want to deal with crises. Daniel was elderly yet lived a "stable life" as an administrator in Babylon. Nevertheless, when he faced danger in his life he called on God for help. Daniel learned the important lesson to call on God when troubles called on him. Through prayer he overcame crises and troubles. This is also an important lesson for the elderly.

\section{Caleb-A Courageous Hero}

Caleb was a mighty soldier, noted for his courage and faith in God. Some elderly are "negative and pessimistic" about things. They lack vigor and courage in their lives. Caleb was eighty-five yet he was still strong, courageous, and optimistic enough to fight the battle as if he were still young (Josh 14:10,11). His courage, vigor, and trust in God throughout his life sets an example for the elderly.

\section{Moses-A Humble Hero}

Moses is called the most humble person on earth (Num 12:3). When he was eighty, God appeared to him and called him to deliver the Israelites. He made one excuse after another (Exod 4:1-17); he did not think he could do the job. God promised to be with him and he eventually obeyed. Thus, he set an example for another group of elderly with "low self-esteem and who lack personal confidence." By trusting God's promises and presence, a person can change things.

\section{Three Elderly Conversions}

A study of three elderly conversions in the Bible provides us with some principles on how to evangelize the elderly. 


\section{Nebuchadnezzar}

The name Nebuchadnezzar, means "may (the god) Nabu protect the son," or "may Nabu protect the boundary.",72

Daniel and his friends were taken to Babylon in the first captivity in 605 B.C., during the course of Nebuchadnezzar's first Syrian campaign.$^{73}$ Ellen White writes that his captivity fit "God's purpose by giving to heathen nations the blessings that come through a knowledge of Jehovah.,"74

God prepared a series of dramatic experiences so that Nebuchadnezzar knew and acknowledged Him as the only true God in heaven. First, the interpretation of Nebuchadnezzar's dream led him to acknowledge to Daniel that the wisdom of God was superior to other gods (Dan 2:47). Second, God's striking deliverance of Daniel's three friends from the fiery furnace led Nebuchadnezzar to admit that He was more powerful than other gods (Dan 3:28, 29). Third, his reason returning to him after seven years made him praise, exalt, and glorify the King of heaven (Dan 4:37).$^{75}$ All these events demonstrated God's knowledge, power, and authority was superior and that He was the only living God in heaven.

${ }^{72}$ The age of Nebuchadnezzar's death is not clear, however, he was the king of Babylon for over 40 years, from 605 B.C. to 562 B.C. When he succeeded to his father's throne, he was already a young crown prince fighting battles, a good guess is that he was already elderly when he was converted and acknowledged the true God. See Seventh-day Adventist Bible Dictionary, s.v. "Nebuchadnezzar."

${ }^{73}$ Ibid. 479.

${ }^{74}$ Ellen G. White, Prophets and Kings (Mountain View, CA: Pacific Press, 1943),

75،"Daniel," Seventh-day Adventist Bible Commentary, ed. Francis D. Nichol (Washington, DC: Review and Herald, 1978), 4:751, 752. 
Ellen White describes his conversion, "For seven years Nebuchadnezzar was an astonishment to all his subjects; for seven years he was humbled before all the world. Then his reason was restored and, looking up in humility to the God of heaven, he recognized the divine hand in his chastisement. In a public proclamation he 'acknowledged his guilt' and 'the great mercy of God' in his restoration. ... The once proud monarch had become a humble child of God ... and earnestly sought to promote the fear of Jehovah and the happiness of his subjects. $" 76$

Daniel and his friends were once captives, but by the design of God they became His representatives to Nebuchadnezzar. Ellen White writes, "They were to be His representatives. Never were they to compromise with idolaters; their 'faith' and their name as 'worshipers' of the living God they were to bear as a high honor." 77 So, through these means they "witnessed" to Nebuchadnezzar about the God they served. ${ }^{78}$

\section{Nicodemus}

Nicodemus, means "leader of the people" in Greek. He was educated and Jesus called him a teacher in Israel (John 3:10). He was old (John 3:4), wealthy (John 19:39), ${ }^{79}$ influential, and a member of the Jewish ruling council (John 3:1). Paulien notes that he

${ }^{76}$ White, Prophets and Kings, 520, 521, emphasis added.

${ }^{77}$ Ibid., 479, emphasis added.

${ }^{78}$ Ellen White writes, "As God called Daniel to witness for Him in Babylon, so He calls us to be His witnesses in the world today." So, Daniel's witness played an important role in leading Nebuchadnezzar to God. See Ibid., 487.

${ }^{79}$ “The family of Nicodemus appears to have been enormously wealthy, and the bringing of huge amounts of spices at royal funerals was familiar to Jews." See George R. Beasley-Murray, John, Word Biblical Commentary, vol. 36, ed. David A. Hubbard and Glenn W. Barker (Waco, TX: Word Books, 1987), 359. 
was "relatively fearless (John 7:45-52; 19:38-42), in spite of the fact that a certain timidity may have caused him to choose the night hours for an interview with Jesus.."80

It is unusual for someone to come at night and no one in Nicodemus' position would come to Jesus at all except through the leading of the Holy Spirit. He saw the miracles that Jesus performed and acknowledged that Jesus was a teacher sent from God (John 3:2). Jesus' words and deeds attracted him to come.

Apparently, he came for a discussion of Jesus' teachings. Jesus unfolded the plan of salvation to him, His message for him was transformation of life, God's kingdom, and the cross (John 3:3-7, 14). Even though he did not become a follower of Jesus immediately, the message left a deep impression on him; "The seed was sown during that night bore fruit in the course of time." ${ }^{81}$ When he saw Jesus hung on the cross, "the light from that secret interview illuminated the cross upon Calvary, and Nicodemus saw in Jesus the world's Redeemer." 82

Here is an elderly man drawn to Jesus by His words and deeds. Here is Jesus' message for that elderly man: a new life, God's kingdom, and salvation. "He spoke with such "solemn dignity," yet His look and tone "expressed earnest love."

${ }^{80}$ Jon Paulien, John: Jesus Gives Life to a New Generation, ed. George R. Knight, The Abundant Life Bible Amplifier (Boise, ID: Pacific Press, 1995), 90.

${ }^{81} S D A B D$, s.v. "Nicodemus."

${ }^{82}$ Ellen G. White, The Desire of Ages (Mountain View, CA: Pacific Press, 1940), 177.

${ }^{83}$ Ibid., 173. 


\section{The 38-year Cripple}

Bethesda, means "house of mercy." 84 It was a gathering place for disabled people; the blind, the lame, and the paralyzed, etc., waiting to get in the pool when the waters were agitated. They believed that the first one who got into the water would be healed. ${ }^{85}$ Five covered colonnades had been erected to protect the sufferers from the heat and cold. Jesus saw one case of supreme wretchedness, a helpless elderly cripple ${ }^{86}$ for thirty-eight years. He bent over him with a tender, compassionate look, ${ }^{87}$ asking if he wanted to get well. He caught his attention by first asking him a question and creating hope for the hopeless. Jesus then said to him, “'Get up! Pick up your mat and walk.' At once the man was cured; he picked up his mat and walked" (John 5:8, 9).

Jesus approached the cripple with what one writer calls a "caring and loving attitude." Jesus "drew his attention" and "created hope" for him. By faith, the invalid believed in Jesus' words, obeyed Him and followed Him, and after thirty-eight years he was healed. Then Jesus told the man to pick up his mat and walk (John 5:8), a public testimony of what had happened to him. ${ }^{88}$

84“John," The Seventh-day Adventist Bible Commentary, ed. Francis D. Nichol (Washington, DC: Review and Herald, 1978), 5:948.

${ }^{85}$ The story of Jesus healing a 38-year cripple is found in John 5:1-14.

${ }^{86}$ From Jesus' warning to him to sin no more (John 5:14) and the comment from Ellen White that "his disease was in a great degree the result of his own sin," we can tell that he was probably an adult when he had sinned, having been sick for 38 years, he was very probable an old man by then. See White, The Desire of Ages, 202.

${ }^{87}$ Ibid.

${ }^{88}$ Ibid., 206. Here, Ellen White uses the phrase "to publish the great work that had been wrought upon him." 
This is Jesus' assistance to the lonely, suffering, and the social vulnerable group; changing people from nobody to somebody. Many feel powerless today. The church needs to go and approach them with a loving attitude, creating hope for them and helping them trust in Jesus' words. It also needs to proclaim and celebrate all the marvelous work it has done for Him. Members must take the initiative to seek, ask, and care for the suffering in our evangelistic activities.

The key words and principles we learn from the conversion stories of these three different groups of elderly, i.e., Nebuchadnezzar, the political group with the "heart" problem (proud—spiritual); Nicodemus, the religious group, with the "head" problem (intellectual), and the 38-year cripple, the social vulnerable group, with the "healing" problem (physical) are worship, testimony, programs, friendship, visitation, and the Bible.

\section{Ellen White and Elderly Evangelism}

Through an examination of the dual biblical mandate and its synthesis in the Great Commission and the Great Commandment, the biblical foundations for elderly evangelism have been established. While Ellen White has been quoted a number of times, it will be beneficial to look more closely at how her writings corroborate the biblical teachings.

Ellen White states that the mission of the church is based on the evangelistic and cultural mandates. She uses the terms "salvation" and "service." For instance, she states that "the church is God's appointed agency for the salvation of men. It was organized for 
service, and its mission is to carry the gospel to the world." 89

Also, her writings are clear on elderly evangelism. "It is wonderful how many aged people the workers find who need but little labor to lead them to receive the truth, Sabbath and all." ${ }^{, 90}$ People of different age levels, including the aged, and professions came to listen to Jesus, "Aged men leaning upon their staffs, hardy peasants from the hills, fishermen from their toil on the lake, merchants and rabbis, the rich and learned, old and young, bringing their sick and suffering ones, pressed to hear the words of the divine Teacher." 91

Further she cites an experience of an elderly conversion she knew about personally. "An old man, about seventy or eighty years of age, was once brought to me, as a monument of God's mercy. I asked him how old he was. He looked at me for a little while, and then said in faltering tones, while the tears ran down his cheeks, 'I am two years old.' I expressed my surprise, and then he said, 'Ah, until two years ago I live the life of a dead man. I never knew what it was to live until I met with the life that is hid with Christ in God." ${ }^{\prime 92}$

When fulfilling the Great Commission, Ellen White confirms that the driving force behind it is love. She writes, "The strongest argument in favor of the gospel is a

${ }^{89}$ White, The Acts of the Apostles, 9, italics added.

${ }^{90}$ Ellen G. White, Evangelism (Washington, DC: Review and Herald, 1946), 446, 447.

${ }^{91}$ White, The Desire of Ages, 245, italics added.

${ }^{92}$ White, Evangelism, 447. 
loving and lovable Christian." ${ }^{.93}$ She further comments, "Love can no more exist without revealing itself in outward acts than fire can be kept alive without fuel."94

Also, in her mind elderly ministry is an important if neglected ministry. She calls for the care of the elderly and to treat them with respect and tenderness. "All who have Christ's spirit will regard the feeble and aged with special respect and tenderness. ${ }^{.95}$ She emphasizes further that respect to the elderly is important, "Help the children to think of this, and they will smooth the path of the aged by their courtesy and respect, and will bring grace and beauty into their young lives as they heed the command to 'Rise in the presence of the aged, show respect for elderly and revere your God. I am the Lord' (Lev 19:32)."96

She mentions that children should be taught to "show kindness to the aged, the sick, and the unfortunate. ${ }^{97}$ She does not neglect the aspect of worship services for the aged, "Let them worship among those whom they have known and loved. Let them be cared for by loving and tender hands." 98

Regarding the cultural mandate, White mentions that the study of Isaiah chapter 58 is important. The words in this chapter comprise the "message for this time" and are 1942), 470.

${ }^{93}$ Ellen G. White, The Ministry of Healing (Mountain View, CA: Pacific Press,

${ }^{94}$ White, Testimonies for the Church, 1:695.

${ }^{95}$ Ellen G. White, The Adventist Home (Nashville, TN: Southern Publishing Association, 1952), 363. 144.

${ }^{96}$ Ellen G. White, Child Guidance (Washington, DC: Review and Herald, 1982),

${ }^{97}$ Ibid., 36. 
of "highest importance ... the kind of ministry [which] will bring life to the church." 99 When doing this work, she says, "we are to mingle compassion for suffering humanity. We are to show supreme love to God ... we are to manifest mercy, benevolence, and the tenderest pity for the fallen race. 'Thou shalt love thy neighbour as thyself.' As a people we must take hold of this work. Love revealed for suffering humanity gives significance and power to the truth."100

On the other hand, as people do the work outlined in Matt 25, they are doing it onto Jesus. This is important because people today "are growing more selfish as they increase in riches. Their love for Christ and His people is decreasing. They do not see the wants of the needy, nor feel their sufferings and sorrows. They do not realize that in neglecting the poor and the suffering they neglect Christ, and that in relieving the wants and sufferings of the poor as far as possible, they minister to Jesus."101

According to Ellen White this is a work of blessings. "Our happiness will be proportionate to our unselfish works, prompted by divine love; for in the plan of salvation God has appointed the law of action and reaction, making the work of beneficence in all its branches twice bless. No one can give place in his own heart and life for the stream of God's blessing to flow to others, without receiving in himself a rich reward."102

\footnotetext{
${ }^{98}$ White, The Ministry of Healing, 204.

${ }^{99}$ White, Testimonies for the Church, 8:159.

${ }^{100}$ White, Welfare Ministry, 32.

${ }^{101}$ Ibid., 39.

${ }^{102}$ Ellen G. White, Healthful Living (Published Payson, AZ: Leaves-of-Autumn
} Books, 1976), 279. 


\section{Summary}

Two words summarize this section-salvation and service. Ellen White puts it this way, "The church is God's appointed agency for the salvation of men. It was organized for service, and its mission is to carry the gospel to the world."103 "Salvation" is found in the Great Commission message and "service" in Isa 58:7-10 and Matt 25:3540. When the message of salvation and service of compassion is demonstrated by love as in the Great Commandment message, humanity is then fulfilling God's purpose for His church. Overall, God requires Great Commitment (passion) in fulfilling the Great Commission; God measures passion by people's compassion.

An understanding of the biblical view of the world shapes members' attitudes toward the people. Our compassion is demonstrated in visitation evangelism as we find out their needs and meet them accordingly. Our hospitality is demonstrated when the elderly come to our programs and worship service. One way this can be done is by shaking their hands during the worship service and also when they leave. Our young people are standing at the door to say good-bye to them. Fellowship is demonstrated during potluck as we serve all the elderly while they sit and enjoy the feast we provide.

The characteristics of the elderly give a background of the elderly which helps the church to develop a strategy to evangelize them. The stories of notable biblical elderly characters exert an influence on the elderly ${ }^{104}$ and thus encourage the elderly to follow

${ }^{103}$ White, The Acts of the Apostles, 9 , italics added.

104'"If by our example we aid others in the development of good principles, we give them power to do good. In their turn they exert the same influence upon others, and they upon still others. Thus by our unconscious influence thousands may be blessed." See Ellen G. White, Christ's Object Lessons (Mountain View, CA: Pacific Press, 1941), 340. 
their example of trusting God. Both the stories of the notable biblical elderly characters and the blessings can be shared during sermons, visitation, and Bible studies. The biblical stories of conversion of the elderly give the church principles to follow in implementing elderly evangelism. All these contribute to the various phases of helping the elderly to accept the gospel. 


\section{CHAPTER 3}

\section{THE SIU SAI WAN SOCIAL CENTER EVANGELISTIC CHALLENGES}

The purpose of this chapter is to describe the inherent evangelistic challenges for elderly evangelism. First, a study is made of the elderly situation in Hong Kong and the challenges it represents in terms of population trends, living conditions, and educational level. Next, the elderly worldview is described to see how the elderly view of their life and the world fits the context, and last, a profile of Siu Sai Wan Social Center for the Elderly is provided.

\section{The Elderly and Their Challenges}

The Elderly Population

In view of the world's rapidly aging population and to enhance the international awareness of aging, in 1992 the United Nations designated 1999 as "The International Year of Older Persons." The trend toward an aging population is also happening in Hong Kong. According to the "2006 Population By-Census": "The number of older persons increased by 764,878 or at an average annual growth rate of $5.1 \%$ over the past 45 years (i.e., from 1961 to 2006). There were 852,796 older persons in Hong Kong in 2006. In

1The terms "older persons," "elderly," "senior adults," and "senior citizens," refer to persons aged 65 and over. When the terms are used in the context of welfare services in Hong Kong they refer to those aged 60 or above. 
terms of the proportion of older persons in the total population, its percentage rose continuously over the past 45 years from $2.8 \%$ (or 87,918 persons) in 1961 to $12.4 \%$ in 2006."

The elderly who were born outside Hong Kong constitutes a large population segment $(79.2 \%)$. Of this group, $75.7 \%$ are from China. Most came to Hong Kong after the Second World War. Overall, $99.2 \%$ of the elderly population is Chinese.

As a group, the elderly are themselves aging. In $1996,36.6 \%$ of the elderly were in the 65-69 age bracket, while $46.0 \%$ were ages $70-79$ and $17.4 \%$ ages 80 and over. The corresponding proportions of the total population were $33.3 \%, 47.1 \%$, and $19.6 \%$ in 2001 and $28.2 \%, 47.9 \%$, and $23.9 \%$ in 2006 . The eighty and over age group has continued to increase. $^{3}$

The median age of the Hong Kong population as of mid-2006 was 39.6, which is projected to increase to 42.1 by mid-2016, 43.8 by mid-2026, and 46.1 by mid-2036. Correspondingly, the elderly population is projected to rise to $15 \%$ of the total population by mid-2016; $22 \%$ by mid- 2026 , and $26 \%$ by mid- $2036 .{ }^{4}$ In other words, the percentage of elderly will rise sharply in the next twenty to thirty years. At present, one in eight persons in Hong Kong is in this group. By 2036, this will increase to one in four persons. The Hong Kong population truly is aging.

2“"Hong Kong 2006 Population By-Census Thematic Report: Older Persons," ed. Census and Statistics Department (The Government of Hong Kong Special Administrative Region, 2006), 333, 334, http://www.bycensus2006.gov.hk/FileManager/ EN/Content_962/06bc_op.pdf (accessed 26 July 2009).

${ }^{3}$ Ibid., 17.

4“"Hong Kong Population Projections 2007-2036," 5. 
The changes in the age structure of the projected population can also be seen in the Elderly Dependency Ratio. ${ }^{5}$ In 1961 the ratio was only 50, but increased to 168 by 2006. As the elderly population has increased and the birth rate has dropped, the Elderly Dependency Ratio is projected to increase to 208 by $2016 ; 336$ by 2026, and 425 by 2036. ${ }^{6}$ John Tsang, the Hong Kong Financial Secretary, expresses concern about the increasingly elderly population: "At present, every two elderly persons are supported by about 12 people of working age. By 2033, however, every two elderly persons will be supported by only about five people of working age. This means that the support burden on each working person will more than double."?

The elderly are also living much longer than previously. In 2006, the life expectancy at birth $^{8}$ for a male was 79.5 years of age, and for a female 85.6. It is projected to increase to 80.6 (male) and 86.3 (female) by $2016,81.9$ (male) and 87.4 (female) by 2026, and 82.7 (male) and 88.3 (female) by $2036 .{ }^{9}$

${ }^{5}$ Hong Kong Census and Statistic Department defines the Elderly Dependency Ratio as "the number of persons aged 65 and over per 1,000 persons aged between 15 and 64." See Ibid., 65.

${ }^{6}$ Ibid., 5.

${ }^{7}$ John C. Tsang, "Speech by the Financial Secretary, Moving the Second Reading of the Appropriation Bill 2008," Wednesday, 27 February 2008, paragraph 32, http://www.budget.gov.hk/2008/eng/speech.html (accessed 26 July 2009).

${ }^{8}$ Life expectancy at birth is also known as Expectation of Life at Birth, which "refers to the number of years of life that a person born in a given year is expected to live if he/she was subject to the prevalent mortality conditions as reflected by the set of agesex specific mortality rates for that year." See "Hong Kong Population Projections 2007$2036, " 65$.

${ }^{9}$ Ibid., 58. 


\section{Living Conditions}

There were 594,730 domestic households with one or more older persons in 2006, which constitutes $26.7 \%$ of the total domestic households. The elderly $(74.7 \%)$ lived with their families (30.4\% with spouse and children; $23.1 \%$ with children only, and $21.2 \%$ with spouse only), while $11.6 \%$ lived alone and $13.7 \%$ in retirement homes, hospitals, or other venues. ${ }^{10}$

There is insufficient housing available for the elderly. This has long been a perplexing problem facing Hong Kong, especially for the elderly citizens themselves, since Hong Kong is a very densely populated city. ${ }^{11}$ Chinese culture traditionally places a great deal of emphasis on filial piety. The Chinese cherish the idea of having a large family with lots of children and grandchildren living under the same roof. Some households have three to five generations living together. It is a prized value to have at least one surviving elder living in the family. The contemporary situation, however, is that more and more of the younger generation are not willing to share being under one roof with the elderly, thus producing a housing shortage for the elderly.

Most of the elderly retire at sixty years of age. According to the 2006 population census, $14.7 \%$ ( $11.6 \%$ for male, $3.1 \%$ for female) were still working after 65 . Their median earnings were HK\$6,500.00 (US\$833.30) per month, which was lower than the Hong Kong average of HK\$10,000.00 (or US\$1,282.10). Most of the elderly were living

10“"Hong Kong 2006 Population By-Census Thematic Report: Older Persons," 10.

${ }^{11}$ The population density in 2007 was 6,410 people per square kilometer, the most densely populated district is Kwun Tong with a density of 51,790 per square kilometer. See "Hong Kong: The Fact," Hong Kong 2007 (Hong Kong: Information Services Department of the Hong Kong SAR Government, 2007), http://www.yearbook.gov.hk/2007/en/pdf/Fact_Eng.pdf (accessed 22 July 2009). 
on savings, ${ }^{12}$ children's financial support, and reliance on the government old age allowance. ${ }^{13}$

In 2008 , there were 483,000 elderly (about $55.5 \%$ of the elderly population) receiving the government old age allowance. This increase in the aging population will undoubtedly engender a financial problem for the Hong Kong Government:

The number of elderly people is expected to increase from the current 870,000 to about 2.17 million by 2033, or two and a half times the present population. The expenditure on the Old Age Allowance will increase accordingly, in today's money, from $\$ 3.9$ billion in 2008 to $\$ 9.7$ billion in 2033 , posing a considerable burden to public finances in the long run. If the Old Age Allowance were increased to $\$ 1,000$ for each eligible person, by 2033 expenditure would surge to $\$ 14$ billion. In the long run, this measure would be unsustainable, and the expenditure involved would become a heavy burden on the community. ${ }^{14}$

${ }^{12}$ According to the research on the source of income for the elderly people in $2000,89 \%$ of the elderly had their income from savings/fixed deposits, or dividends from stocks, $58.4 \%$ from their children, and 51.6\% from Old Age Allowance. See "Social Data Collected Via the General Household Survey: Special Topics Report--Report No. 27," ed. Census and Statistics Department (The Government of Hong Kong Special Administrative Region, 2000), 86, http://www.censtatd.gov.hk/products_and_services/ products/publications/statistical_report/social_data/index_cd_B1130127_dt_a latest.jsp (accessed 27 July 2009).

${ }^{13}$ There are two kinds of old age allowances for the elderly which are under the Social Security Allowance Scheme. First, the Normal Old Age Allowance is for those aged between 65-69 and having an income and assets below the prescribed limits; second, Higher Old Age Allowance is for those who are 70 or over, which is non-means-tested. The allowances have been increased from HK\$625.00 (or US\$80.10) and HK\$705.00 (or US\$90.40) respectively to both HK\$1,000.00 (or US\$128.20) per month since January 1 , 2009. See "Social Security Allowance Scheme," ed. Social Welfare Department (The Government of Hong Kong Special Administrative Region), http://www.swd.gov.hk/en/index/site_pubsvc/page_socsecu/sub_ssallowance/ and http://www.swd.gov.hk/en/textonly/site_whatsnew/year_1507/(accessed 22 July 2009).

${ }^{14}$ Tsang, paragraph 158 . Note that Hong Kong currency is used here, US\$1 is equivalent to $\mathrm{HK} \$ 7.80$. 


\section{Educational Level}

Many of the elderly in Hong Kong are illiterate, especially the female population. The background of this is that opportunities for education during the 1930s through the 1950s were not very well developed in Hong Kong. As a result, according to the census reports, "the current cohort of older persons on average had relatively low level of educational attainment. The education level of the younger cohort of older persons was improving. $" 15$

According to the 2006 census, the number of male elderly with no schooling/preprimary was $77,257(19.6 \%$ of the male elderly population of 393,412$)$ and 228,307 for the female elderly $(49.7 \%$ of the female elderly population of 459,384$)$, which makes a total of 305,564 elderly ( $35.8 \%$ of the total elderly population of 852,796$)$. Many of the elderly immigrated from China when they were young. The opportunity of attending school was slim, especially for the females from rural villages. Also, the older the group became, the lesser education they received. Only a little over one third (39.2\%) of the elderly population received primary education (grade 1-7), 18.4\% received secondary/sixth form education (grade 7-12), and $6.6 \%$ post-secondary education. ${ }^{16}$

The figures for the elderly population with no education or only primary education have decreased (thus improved) over the years from $83.9 \%$ in 1996 , to $81.6 \%$ in 2001 , and $75 \%$ in $2006 .^{17}$

15“"Hong Kong 2006 Population By-Census Thematic Report: Older Persons," 25. Younger cohort of older persons refer to those aged 65-69.

${ }^{16}$ Ibid., 26.

${ }^{17}$ Ibid., 12. 
It is worth noting that educational attainment is linked to many aspects of a person's development. The census report comments that "research has shown that higher levels of education usually translate into better health status, higher incomes and consequently higher standards of living. People with higher educational levels may be less dependent on their family for financial assistance." 18

Illiteracy among the elderly affects their knowledge and limits their capacity for living independently and in daily activities such as using public transportation. In turn they become more like shut-ins. Some do not know how to use household appliances such as washing machines, home entertainment system, water heater, etc. They have difficulty handling bill payment, reading medical prescriptions, and understanding their bank statements. They have to rely on routines that they follow day in and day out, or to depend on someone else to manage their daily affairs. ${ }^{19}$ These are the challenges the elderly face and leads them to be regarded as a socially vulnerable group.

\section{Worldview of Elderly in Hong Kong}

Barna defines worldview as "the product of all the information, ideas, and experiences you absorb to form the values, morals, and beliefs that you process. ${ }^{, 20} \mathrm{It}$ is

18،"Hong Kong 2006 Population By-Census Thematic Report: Older Persons," 25.

${ }^{19}$ Pui Lan Chu, Elderly Care and Social Work (Hong Kong: The Chinese University Press, 2001), 31.

${ }^{20}$ Barna, 35. 
the life lens, the most general and characteristic about a people, ${ }^{21}$ the very core of culture. $^{22}$

$\mathrm{Ng}$ notes that "the traditional Chinese worldview was strongly oriented to the past. The past was regarded as the model for the present and the primary source of information on human society. ${ }^{23}$ It may be seen in areas of ancestor worship, filial piety, a strong sense of family traditions, and an almost compulsive concern with record keeping. ${ }^{24}$ This forms and shapes the Chinese elderly worldview, for the elderly are known to be very traditional.

\section{Filial Piety}

Hsiao, in Chinese means "filial piety." The Chinese are famous for their filial piety. It is not just theoretical, but highly pragmatic. ${ }^{25}$ Filial piety is the "appropriate behavior and attitude of duty toward one's parents, the elderly within the family, and

${ }^{21}$ Gan-Theow Ng, "Religion, Culture, and Modernity: Some Missiological Implications of the Process of Secularization in East Asia" (Ph.D. dissertation, Andrews University, 1991), 43.

${ }^{22}$ Culture has several layers. The most outstanding is behavior, followed by values and beliefs, and the innermost component is the worldview. See Ralph D. Winter and Steven C. Hawthorne, Perspectives on the World Christian Movement: A Reader (Pasadena, CA: William Carey Library, 1981), 361-364.

${ }^{23} \mathrm{Ng}, 114,115$. Also, Nakamura describes eleven Chinese attributes of their way of thinking, one is "Conservatism expressed in the exaltation of antiquity," see Hajime Nakamura, Ways of Thinking of Eastern Peoples: India, China, Tibet, Japan, ed. Philip P. Wiener (Honolulu: University of Hawaii Press, 1971), 175-294.

${ }^{24}$ Michael Kearney, World View (Novato, CA: Chandler \& Sharp, 1984), 97.

25徐松石, 聖經與中國孝道 (The Bible and Chinese Filial Piety) (香港: 浸信會 出版社, 1991), 15. 
one's ancestors."26 The Chinese believe filial piety is their cardinal virtue, and it influences all actions of life.

The concept of filial piety is summed up in a Confucius dictum, "When the parents live, serve them with decorum; when they are dead, bury them with decorum, and sacrifice to them with decorum."27 This means to give honor and respect to parents and material support to the elderly. For Chinese, serving aged parents is the greatest service. ${ }^{28}$ To the Chinese mind, the elderly feel honored when they have children who fulfill their duty of filial piety toward them.

Filial piety is not a one-sided relationship, it is mutual. Hsu observes, "In the Chinese context, the son owes to his father absolute obedience, support during his life time, mourning when he passes away.... But the father must provide for his sons when they are young, educate them in the ancestral tradition, find mates for them, and leave them good names and ample inheritances." 29

Filial piety is also demonstrated at the funeral. Hsu observes that the dead should

${ }^{26}$ Choi, 111 .

${ }^{27}$ William E. Soothill, The Analects of Confucius, 2nd ed. (New York: Paragon Book Reprint Corp., 1968), 153.

${ }^{28}$ The Four Books: Confucian Analects, the Great Learning, the Doctrine of the Mean, and the Works of Mencius, trans. James Legge (Shanghai: Chinese Book Co., 1933), 719, 726, 763. Confucius (557-479 B.C.) has been acclaimed as the first major social philosopher. His teachings and philosophy have deeply influenced Chinese culture. Mencius (most probable 372-289 B.C.), a philosopher and sage, and one of the principal interpreters of Confucianism, was arguably the most famous Confucian after Confucius himself.

${ }^{29}$ Francis L. K. Hsu, "Filial Piety in Japan and China: Borrowing, Variation and Significance," Journal of Comparative Family Studies 2 (Spring 1971): 68. 
be "buried with great ritual and ceremonial pomp."30

Lukas Tjandra's Folk Religions in the E-Era summarizes Chinese filial piety in fifteen criteria: (1) show respectful love to parents, (2) be obedient to parents, (3) when it is necessary to correct parents, do it with the utmost politeness, (4) serve parents with utmost respect, (5) inherit and continue parents' cause and ambition, (6) bring honor to family, (7) remember one's own parents, (8) entertain parents in a proper way, (9) do not make parents worry, (10) stay and serve your parents, (11) provide for your parents physically and mentally, (12) take good care of one's self, (13) have offspring, (14) after parent's passing, make proper arrangements for burial, and (15) after parent's passing, honor their memory in proper ritual. These criteria are mostly in harmony with the Bible.

The last two criteria, however, have to do with ritual. These rituals should be carried out properly and reasonably in a solemn and respectful way. They demonstrate an inward respect and love and represent more than just outward ceremony. As time passed, society changed these criteria in ways that mixed them with other religions, making them more superstition-oriented and extravagant, a departure from the original intent. ${ }^{31}$

Long before Confucius, when the Chinese invented the Chinese characters of the language, ${ }^{32}$ they placed the word 孝(filial piety) as part of the Chinese character, 教

${ }^{30}$ Francis L. K. Hsu, Americans and Chinese: Passage to Differences, 3rd ed. (Honolulu: University of Hawaii Press, 1981), 299.

${ }^{31}$ 陳潤棠, E-世代的民間宗教 (Folk Religions in the E-Era), 破迷，䦣邪，䞨鬼 ! 第三集 (Against Superstition, Witchcraft, and Demon Possession), vol. III (香港: 金燈 臺出版社, 2003), 106, 107. See also, 基督徒與敬祖 (Christian Alternatives on Ancestor Practices), ed. 教會更新研究發展中心 (台北: 中福出版有限公司, 2000), 38-41.

${ }^{32}$ Chinese characters, a pictorial language, were originally hieroglyphics. They are simplified pictures of objects. 
(teach), which is incorporated into such terms as 教育(education) and 宗教(religion). It means that "filial piety" forms an important element in "education" and "religion."33 That is why we see filial piety as the fundamental teaching of Confucian canons and an important element of ancestor worship.

\section{Ancestor Worship}

The Chinese believe that their ancestors' spirit continues to exist, so ancestor worship is considered to be a continual expression of filial piety. It is one of the most important institutions. It has been an important part of Chinese culture since the beginning of Chinese history. ${ }^{34}$

Ancestor worship has three important meanings for the elderly: $:^{35}$

1. Ancestor worship is a family religious activity; it is a continual relationship between the deceased and the living, and remembrance of their ancestors. ${ }^{36}$

2. The departed ancestors need to be cared for. The male heir has to offer the deceased ancestor food and burn life-sized paper models of "clothing, furniture, sedan chairs, horses, donkeys, cows, and servants" ${ }^{\$ 7}$ to the ancestors.

33 徐松石, 19.

${ }^{34}$ H. G. Creel, The Birth of China: A Study of the Formative Period of Chinese Civilization (New York: F. Ungar Publishing, 1937), 80, 126, 174.

${ }^{35}$ 者樂無躬一長者霝性閶顧的初探與實踐 (A Joyous Golden Age: Exploration and Practice on Spiritual Care for the Older Persons), ed. 勞家怡 (香港: 基督教靈實協 會, 2004), 30.

36黃伯和等著, 基督徒與祭祖 (Christians and Ancestor Worship) (台北: 雅歌出 版社, 1996), 20.

${ }^{37}$ William Theodore De Bary, Sources of Chinese Tradition (New York: Columbia University Press, 1960), 35, 36. 
3. The Chinese believe that their ancestors' spirits continue to exist, and have "power over the living, whether to protect or bless them.,"38

Henry Smith in his doctoral research on the nature of ancestor worship in Hong Kong, a cosmopolitan social environment which mixes traditional and modern customs and values, finds that ancestor worship in Hong Kong is more along the lines of "feelings of filial attachment and responsibility" than "feelings of religious need and concern." 39 He concludes that "the average worshipper's feelings while participating in ancestral rites focus more on family identity and continuity than on spiritual potency and need. ${ }^{, 40}$ His research focuses on the motives behind their participation, and he finds that most interviewees identified with the familial motives of respect, love, and gratitude. Thus he concludes that "the strongest motives for ancestor worship are those that reinforce family identity and solidify family bonds. ${ }^{, 41}$

The study also further points out that belief in the power of ancestors to affect the living is minimal. Only $28.2 \%$ of the sample aligned with the traditional theory that the

${ }^{38}$ Julia Ching, Chinese Religions (Maryknoll, NY: Orbis Books, 1993), 35.

${ }^{39} \mathrm{~A}$ total of 163 Hong Kong residents (only 102 were counted for this section of the survey) were involved in the survey about ancestor-related beliefs and practices. Their responses on their feelings during ancestor worship were: respect for ancestors, 95\%; gratitude to ancestors, $79 \%$; sense of family belonging, 79\%; personal satisfaction, $73 \%$; affection for the deceased, $67 \%$; sense of need, $44 \%$; fear of displeasing dead, $40 \%$; concern for condition of dead, 37\%; pride for their achievements, $29 \%$, and shame for your failures, $21 \%$. See Henry Newton Smith, "Chinese Ancestor Practices and Christianity: Toward a Variable Contextualization of Christian Ethics in a Hong Kong Setting" (Ph.D. dissertation, Southwestern Baptist Theological Seminary, 1987), 39-41.

$$
{ }^{40} \text { Ibid., } 41 .
$$


ancestors have power to bless their descendents; the majority denied it. ${ }^{42} \mathrm{~A}$ similar result was apparent regarding their confidence in prayer to the deceased when encountering trouble. The study indicated that $70.6 \%$ said they never appealed to the ancestors for assistance; $10.4 \%$ seldom did so, $14.1 \%$ sometimes did, and only $4.9 \%$ usually asked for ancestral assistance in times of difficulty ${ }^{43}$ The results clearly show that when they have little confidence in the power of the deceased ancestors, they obviously pray less.

Smith concludes, "These answers imply that the Hong Kong Chinese approach their ancestors not out of fear, and seldom for assistance. On the contrary, filial concern seems to be the primary stimulus for communicating with the departed." ${ }^{44}$ Ying and Leung also agree that ancestor worship in Hong Kong has no strong religious motives; social and ethical motives are their main concern. ${ }^{45}$

Whether ancestor worship is idol worship or can be considered a memorial service has long been debated. It is true that some of the practices in ancestor worship are not acceptable in Christianity, but what can be appreciated is the filial piety that motivates the practice.

Five-Step Witnessing Approach to Ancestor Worship

Emphasis on filial piety forms a powerful bridge in witnessing to ancestor

${ }^{42}$ Of the respondents $57.1 \%$ answered "no power;" $14.7 \%$ "very little;" $26.4 \%$ "some power," and only $1.8 \%$ "great power." See Smith, 62, 63.

${ }^{43}$ Ibid., 64, 65.

${ }^{44}$ Ibid., 68, 69.

${ }^{45}$ 邢福增 and 梁家麟, 中國祭祖問題 (Chinese Ancestor Worship) (香港: 建道神 學院 基督教與中國文化研究中心, 1997), 157. 
worshippers. The Four-stage Elderly Evangelism Model uses a five-step witnessing approach to ancestor worship: $:^{46}$

1. An application of the findings in Smith's research that the main motive behind ancestor worship is really about filial piety.

2. Associates ancestor worship with fact that Christianity also emphasizes filial piety as shown in the fifth commandment of the Decalogue: "Honor your father and your mother, so that you may live long in the land the LORD your God is giving you" (Exod 20:12). This is also the first commandment containing a promise (Eph 6:2).

3. Explains that when one dies, one is asleep (1 Thess 4:13), so there is no need to worship deceased ancestors, because they do not know, feel, or do anything (Eccl 9:5, 6). Instead, one should worship the Father of forefathers, that is our heavenly Father. Our first forefather was Adam, and Adam is "the son of God" (Luke 3:38).

4. Emphasizes that filial piety should be practiced while the parents are alive, not when they are dead. Chinese hold the strong conviction that one's life fulfillment is to honor one's parents and one's ancestors. Using a Christian contextualization of ancestor worship, it is emphasized that when parents die the children can alternatively honor them by taking good care of the next generation. This can be done by educating them, and most importantly, teaching them to worship God so they will be under the special care and blessings of God and will have a bright future (Ps 37:25). This is a good way to honor the deceased parents and to practice filial piety.

${ }^{46}$ Terry Tsui, "Five-Step Witnessing Approach to Ancestor Worship," Kaohsiung Evangelistic Series, Taiwan, 2009. This strategy was developed by Terry Tsui when he was conducting an evangelistic series. While visiting an old lady, he found she was troubled in deciding to be baptized as she was an ancestor worshipper. After listening to this five-step approach, she burst into tears and found relief in following Christ. 
5. Ancestor worship is also about remembrance of ancestors. Prayers are used to replace incense, pictures of the deceased replace the wooden altar, and flowers replace offerings of meat and fruits, etc., as commonly done in ancestor worship practice. ${ }^{47}$ It is impossible for people to change all in a sudden, it takes time. So, by introducing the replacement of some of the practices in ancestor worship, it will help them to maintain the consciousness of their ancestors, yet to eliminate those practices in a more natural and acceptable way. So, these practices help the elderly to respect their ancestors, but in their minds they do not worship them.

\section{Values in Elderly Thinking Patterns}

Apart from filial piety and ancestor worship, the Hong Kong elderly value such things as family relationships and closeness, friendships, longevity, dignity and money.

The teachings of Confucius strongly emphasize human relationships; therefore the elderly enjoy relationships and closeness with their children. Choi observes that "the elderly considered it a great blessing to be supported by their children and to live with children and grandchildren. On the other hand, the elderly were greatly ashamed when they had no children to support them and live with them." saying describes the mind of the Chinese: "Having an elderly at home is like having a treasure."

The elderly also care about relationships. Sometimes, in order to maintain the

\footnotetext{
${ }^{47}$ Traditionally, Chinese have an altar at home. Wooden tablets on the altar are inscribed with the names of the deceased ancestors of the family. They burn incense and offer meat or fruit in an ancestor worship ceremony.

${ }^{48}$ Choi, 48.
} 
relationships they will make personal concessions. To avoid conflicts, or to avoid offending others and to maintain harmonious relationships they prefer to be silent, retire, control themselves, or simply endure whatever the situation may be. It is hinted in some of the elderly pronouncements that it does not matter to them if they live or die since they have no relatives or friends. ${ }^{49}$ Furthermore, Tam observes that the elderly especially need a community to support them when they are facing crisis in the last one third of their lifetime. $^{50}$

A Chinese person is considered to be old when he or she reaches the age of sixty. This can be seen in the lunar calendar which consists of sixty-year cycles, thus, the sixtieth birthday to the Chinese is a big event and marks the beginning of a new cycle. ${ }^{51}$

Chinese view longevity as a blessing. In Hong Kong the elderly love to be praised that they are old but look young. Kim explains that age itself has a certain dignity. This can be understood by an oriental saying, "The span of life depends on Heaven's will." So, old age is a special blessing, and is understood as "containing a certain dignity within itself. ${ }^{, 52}$ Furthermore, dignity is important to the elderly because they have rich experiences in life and many have made contributions to society. To both Chinese and

${ }^{49}$ 者樂無第一長者需性閶顧的初探與實踐 (A Joyous Golden Age: Exploration and Practice on Spiritual Care for the Older Persons), 8.

${ }^{50}$ 譚司提反, 老當益壮一長者生命成長路 (Aging with Vitality: A Path for Growth) (香港: 更新資源 (香港) 有限公司, 2000), 333, 334.

${ }^{51}$ Choi, 39, 40.

${ }^{52}$ David Myong-Uk Kim, "A Study for Effective Ministry with the KoreanAmerican Elderly" (D.Min. dissertation, School of Theology at Claremont, 1996), 13, 14. 
biblical Hebrew cultures, the elderly are called "the wise"53 (see also Job 12:12). They constantly need affirmations that this is true. The Hong Kong Social Welfare Department understands that the elderly need this affirmation of their identity and dignity, so they issue a senior citizen card to those who are 65 or over. With this card, they get discounts and many elderly are proud of having it. ${ }^{54}$

Money to the elderly mind is also important. Many have experienced the hardships of life and the trial of wars. As a result, they have learned to be thrifty. When they are getting old, they spend more on medical bills and they need to save money for their funeral expenses. Also, when they have money in hand Chinese tend to give gifts to relatives and friends that help them "feel less inferior." 55

The Biblically-Shaped Worldview and Its Benefits

Having mentioned the elderly worldview, it is worthwhile to also mention the biblically-shaped worldview since our goal is to help the elderly to adopt and develop the biblically-shaped worldview. Barna describes the biblically shaped worldview as "a means of experiencing, interpreting, and responding to reality in light of biblical perspective." It is thinking like Jesus, based on the Word of God, and focusing on

${ }^{53}$ 周李玉珍, 松柏之音 (The Voice of the Elderly) (香港: 伯特利神學阮, 1997), 9.

${ }^{54}$ The Senior Citizen Card is provided by the Social Welfare Department, which provides a generally recognized proof of age to senior citizens so as to facilitate their access to concessions, discounts or priority services offered by Government departments, public companies, private and commercial establishments. The Scheme aims at promoting a spirit of respect for the senior citizens. See "Senior Citizens Card Scheme," ed. Social Welfare Department (The Government of Hong Kong Special Administrative Region), http://www.swd.gov.hk/en/index/site_pubsvc/page_elderly/sub_csselderly/ id_seniorciti/ (accessed 26 July 2009).

${ }^{55}$ 周李玉珍, 63, 78. 
knowing and fulfilling the will of God; "a way of making our faith practical to every situation we face each day. ${ }^{, 56}$

Changing the elderly traditional worldview to a biblical worldview takes time. Barna's seven-question process ${ }^{57}$ provides a conceptual basis for developing a biblicallyshaped worldview. I revised and adapted his list to the elderly setting as a five-step process. The process deals with issues that are relevant to the elderly mind and worldview: (1) God, His nature and characters, and Jesus' life; (2) man, dealing with life and death; (3) this life, dealing with the ten commandments, especially the fifth one that goes along with filial piety; (4) life to come, dealing with heaven; and (5) salvation. ${ }^{58}$

Moreover, the elderly mindset likes blessings. Introducing the benefits of having a biblically-shaped worldview will attract the elderly to the Lord of the blessings. Barna provides a very comprehensive list of the benefits of having a biblically-shaped worldview that is helpful. ${ }^{59}$

${ }^{56}$ See Barna, 20-23.

${ }^{57}$ The seven questions are: 1 . Does God exist? 2. What is the character and nature of God? 3. How and why was the world created? 4. What is the nature and purpose of humanity? 5. What happens after we die on earth? 6. What is truth? 7. What spiritual authorities exist? See Ibid., 69-154.

${ }^{58}$ The "fifth commandment" forms a bridge on their worldview on filial piety; the "death message" addresses the ancestor worship issue, "salvation" provides dignity, "heaven" brings hope of a family concept, eternal life and end of suffering, and "ten commandments" gives the moral basis.

${ }^{59}$ Barna, based on Prov 1-8 and Matt 5:12, 18, lists the benefits of having a biblical worldview. They are: (1) physical: protection, long life, vitality, and sound sleep; (2) attitudinal emotional: joy, fulfillment, happiness, no fear, and self-control; (3) decision making: wisdom, good plans, direction, discretion, and insight; (4) relational: human acceptance, honor, good reputation, respect, and justice; (5) spiritual: God's approval, heavenly rewards, forgiveness, and mercy, and (6) lifestyle: success, wealth, blessings, and abundant life. See Barna, 30. 


\section{Siu Sai Wan Social Center Profile}

There are four elderly social centers run by the Hong Kong-Macao Conference of Seventh-day Adventists. They are Eden Villa, Heng On, Siu Sai Wan, ${ }^{60}$ and San Po Kong. Eden Villa is a live-in facility providing accommodations for the elderly and is financed by the Hong Kong-Macao Conference. The other centers are largely subsidized by the government. A general picture of the key data of the four centers is shown in table 1.

Each social center has a person in charge, a social welfare worker, and some program assistants. In order to become a member of the elderly center, one has to reach sixty years of age. The elderly are mostly illiterate and from mainland China. The total membership of the four elderly social centers is 2,617 . The social centers provide different activities and services during the weekdays. Each is a place for learning, social, fellowship, and assistance for the elderly.

A church is attached to each of the social centers, providing spiritual activities on Sabbaths. Each serves as a base for sharing the gospel.

${ }^{60}$ Siu Sai Wan Social Center for the Elderly has expanded its services to a "Neighborhood Elderly Center" since April 2003. "It is a type of community support services at neighborhood level which provides a range of comprehensive services to cater for the psycho-social and developmental needs of both healthy and mildly frail elders, including, educational and developmental activities, volunteer development, career support service, counseling service, reaching out and networking, social and recreation activities, meal service, drop-in service, Information and referral centre on community resources." See "Elderly Service in Hong Kong." 
Table 1. Data on Four Elderly Social Centers

\begin{tabular}{lrrrc}
\hline Data & Eden Villa & Heng On & Siu Sai Wan & San Po Kong \\
\hline Year of Opening & 1976 & 1988 & 1993 & 1998 \\
Staff & & & & \\
Volunteers & 4 & 4 & 7 & 7 \\
Members & 0 & 148 & 112 & 115 \\
Activities & 70 & 920 & 851 & 776 \\
Sabbath Attendance & 125 & 112 & 273 & 324 \\
Total Elderly Baptism & 15 & 15 & 95 & 35 \\
& 2 & 4 & 113 & 15 \\
\hline
\end{tabular}

Note: All data is as of March 31,2008, except activities which are for the yearly period April 1, 2007 to March 31,2008. Members and elderly baptisms are accumulative since opening.

Siu Sai Wan Social Center for the Elderly was officially opened on October 4, 1993, and the church opened on the following Sabbath, October 9. There are various activities and classes offered in Siu Sai Wan Center, such as, literacy, singing, folk dancing, English, simplified Chinese writing, and computers, etc. Sport and exercises classes include ping-pong, lion dancing, and aerobics, etc. Services like physical check ups, hair cutting, and a mini cafeteria, etc. are also offered.

Out of the 851 members, there are 193 males and 658 females, and the distribution of the age groups are shown in table 2. 
Table 2. Distribution of Age Groups in Siu Sai Wan Center

\begin{tabular}{ccc}
\hline Age Group & Number of Elderly & $\%$ \\
\hline $60-65$ & 68 & 8.0 \\
$66-70$ & 110 & 12.9 \\
$71-75$ & 187 & 22.0 \\
$76-80$ & 236 & 27.7 \\
Over 80 & 250 & 29.4 \\
\hline
\end{tabular}

Note: All data are as of March 31, 2008.

Table 3 shows the household composition of the elderly. Those living with family or relatives are 71.4 percent. Generally the single elderly are more receptive to the gospel because they tend to be more lonely.

Table 3. Household Composition of the Elderly

Household Composition Number of Elderly $\quad \%$

Living with Children

Living with Spouses

Living Alone

Living with Relatives

Others

$\begin{array}{crr} & 384 & 42.8 \\ & 243 & 27.1 \\ & 236 & 26.3 \\ & 13 & 1.5 \\ & 21 & 2.3 \\ \text { Total } & 897 & 100\end{array}$

Note: All data is as of October 31, 2008 in Siu Sai Wan Center. Living alone or "singles" refer to the single elderly who are either living by themselves, or with those, such as children or spouses, who are also over 60 years of age. 
According to the "2006 Population By-Census," the population in Siu Sai Wan community is 59,493 , and the elderly population is 8,879 or $14.92 \%$. There is one elderly home and three centers serving the elderly population in this community, which means our center alone is serving about $9.58 \%$ of the community elderly population. ${ }^{61}$

As mentioned, there is a church attached to each center. My husband, Terry, served as the original pastor of Siu Sai Wan Church, and I helped on Sabbaths. One year later, when my husband was transferred to another church, I succeeded him as pastor, serving for almost fifteen years until March 31, 2009.

In order to effectively evangelize the elderly in the center, I try to mingle with them by leading out in some activities such as gospel opera singing and gospel tea parties, helping with visitation and some social activities, and leading out in weekly worships for the center staff. The center staff have been outstandingly supportive of our ministries. They often help out, lead out, and refer us to the elderly who show interest in the gospel. We work hand in hand in ministering to the social and spiritual needs of the elderly.

\section{Summary}

The Hong Kong population is notably aging. It is projected that the elderly population will go from $12.4 \%$ of the total population in 2006 to $26 \%$ by mid-2036. That means in 2006 one in eight persons is elderly, a figure that will increase to one in four by 2036. The Elderly Dependency Ratio is also increasing, from 168 in 2006 to 425 in 2036.

${ }^{61}$ Siu Sai Wan community includes areas in Tsui Wan, Yan Lam, Siu Sai Wan, and King Yee. See "2006 Population By-Census," ed. Census and Statistics Department (Hong Kong: The Government of Hong Kong Special Administrative Region, 2006), 102-109. 
Life expectancy is projected to increase from 79.5 years of age for males and 85.6 for females in 2006 to 82.7 (male) and 88.3 (female) in 2036. This increase will engender a major financial concern for the government.

The median earnings for the elderly was HK\$6,500, which was lower than the Hong Kong median salary of HK\$10,000. Most of the elderly were living on their savings, children's financial support, and the old age allowance. Their illiteracy, $35.8 \%$ in 2006 census, made their living standards and incomes lower, and they had to rely on someone else for their daily affairs.

The elderly are well known to be traditional and to inherit a large proportion of the traditional Chinese worldview on ancestor worship, filial piety, and family traditions. Filial piety is the principle motivation behind ancestor worship. According to Smith's research on the Hong Kong elderly, in ancestor worship social motives seem to be stronger than religious motives. Apart from ancestor worship and filial piety, the elderly value family relationships and closeness, friendships, longevity, dignity, and money, etc.

A profile of Siu Sai Wan Social Center for the Elderly gives the background of the center. There were 897 members in the center in October $2008,71.4 \%$ of them were living with their family or relatives.

This chapter helps identify the situation of the elderly, their worldview, and values in general and provides a background of the elderly in the center, which identifies some important concepts in elderly evangelism in the context of the elderly social center. 


\section{CHAPTER 4}

\section{FOUR-STAGE ELDERLY EVANGLISM MODEL}

The purpose of this chapter is to explore some principles of effective elderly evangelism. These principles are based on and derived from the theoretical foundations developed in chapters 2 and 3 . The methodologies included in the Four-stage Elderly Evangelism Model are: (1) Visitation Evangelism, (2) Friendship Evangelism, (3) Culturally-relevant Competent Programs, and (4) Dynamic Worship. These methodologies are discussed using the following titles: (1) From House to House, (2) From Confrontational Evangelism to Friendship Evangelism, (3) From Chinese Festivals to Celebration and Feast, and (4) From Worshipping Forefathers to Worshipping the Heavenly Father.

\section{Introduction}

Based on the theoretical base established in chapters 2 and 3, four principles of elderly evangelism are proposed. The first principle, termed "Visitation Evangelism," is based on Jesus' Great Commission of "going" and on His visitation of the 38-year cripple. This principle provides a platform for the members to share their testimonies.

The second principle, termed "Friendship Evangelism," is based on the fact that Jesus constantly demonstrated loving care to people, especially in the example of the 38year elderly cripple. This principle takes into consideration that the Great Commandment 
of love is the basis and driving force of the Great Commission. Further, Barna's research on the effectiveness of different methods applied to different age groups shows that "lifestyle/friendship" is one of the most effective approaches to the evangelization of senior citizens. ${ }^{2}$

The elderly Nicodemus was attracted by Jesus' words and deeds. This would indicate that sermons and experiential events are important, leading to the principle of "Culturally-relevant Competent Programs" to attract seekers.

King Nebuchadnezzar came to know God through the testimony of Daniel and his worship of the true living God. This leads to the principle of "Dynamic Worship."

These four principles make up the methodological foundation of the Four-stage Elderly Evangelism Model. Its contents include visiting and seeking the lost, building friendships of loving and keeping in touch with the elderly, attracting them and getting them involved in church competent events, and helping them experience and worship the living God. What follows is a detailed delineation of how each principle is conceptualized and applied in the Four-stage Elderly Evangelism Model.

\section{Principle 1: From House to House}

This stage of the Four-stage Elderly Evangelism Model incorporates visitation

l“Lifestyle evangelism refers to the process through which the everyday words and deeds of a maturing Christian draw others to Christ. It involves living a good testimony before the lost and thus developing opportunities to present the gospel." See Carlos G. Martin, Turning the World Upside Down (Ontario, Canada: Pacific Press, 2000), 53.

${ }^{2}$ Barna's research also highlights "literature outreach" as highly effective. This is not included in the present project because at Siu Sai Wan Center most members are illiterate. See George Barna, The Habits of Highly Effective Churches: Being Strategic in Your God-Given Ministry (Ventura, CA: Regal Books, 1999), 118. 
evangelism as an important methodology of elderly evangelism. It should be pointed out that all too often in the Adventist mind the word "visitation" is perceived primarily as referring to knocking on unknown doors on Sabbath afternoon to hand out a piece of literature. That is one type of visitation strategy, but it is not the only kind of visitation that will be studied here. Visitation ministry goes much deeper than a single strategy, as important as that strategy may be.

\section{Meaning of Visitation}

In Luke 1:68, "Visited," (Greek episkeptomai) is defined as "“to inspect," 'to examine,' in the sense of looking into a matter with a view to giving assistance." ${ }^{3}$ This word is translated as "visited" (ASV, KJV, NAB, NKJV, and NLT), "come to the help of" (TEV), and "looked favorably" (NRSV). In the Septuagint (LXX) it represents the Hebrew, pāqad, "which is used often to denote God's gracious visitation, bringing deliverance in various forms (Gen 21:1; Exod 4:31; Ruth 1:6; Ps 80:14; Ps 106:4; Jer $15: 15$, etc.)." 4

In Acts 7:23, episkeptomai has the meaning '“to look upon,' in order to see how a person fares." ${ }^{, 5}$ In Acts 15:14, "the connotation [is], with kindness (see Luke 1:68; 7:16;

3“"Luke," The Seventh-day Adventist Bible Commentary, ed. Francis D. Nichol (Washington, DC: Review and Herald, 1978), 5:690.

${ }^{4}$ John Nolland, Luke 1-9:20, Word Biblical Commentary, vol. 35A, ed. David A. Hubbard and Glenn W. Barker (Dallas, TX: Word Books, 1989), 85.

5“Acts," $S D A B C$, 6:200. 
Heb 2:6)." James 1:27 uses the word "with the idea of looking after," and in Ps 106:4, it “anticipates the coming of salvation and brings together 'visit,' 'people,' and 'salvation' (cf. Luke 1:69)."8 All these various usages contribute to a range of dimensions of the meaning of visitation and help in understanding the usage of visitation in the Bible and in designing our visitation programs.

\section{Importance of Visitation}

Visitation ${ }^{9}$ is "a lost art in many churches." ${ }^{10}$ McDill describes it as "costly," easily neglected work, while White categorizes it as "the most essential work that can be done." 12 For pastors this work "will make the preaching of the Word a success,"13 and of tenfold accomplishment. ${ }^{14}$ According to White, if visitation is omitted the preaching of an

6“Acts," SDABC, 6:309.

7"James," The Seventh-day Adventist Bible Commentary, ed. Francis D. Nichol (Washington, DC: Review and Herald, 1978), 7:515.

${ }^{8}$ Nolland, 85 .

${ }^{9}$ Visitation as used in the Bible and the writings of Ellen White is often referred to as "house to house" work.

${ }^{10}$ Kennon L. Callahan, Twelve Keys to an Effective Church (San Francisco: Harper \& Row, 1983), xiii.

${ }^{11}$ Costly not in terms of money or equipment, but in terms of personal commitment. See Wayne McDill, Making Friends for Christ (Nashville, TN: Broadman Press, 1979), 15.

${ }^{12}$ White, Evangelism, 430.

${ }^{13}$ Ibid., 433.

${ }^{14}$ “'Remember that a minister's work does not consist merely in preaching. He is to visit families in their homes, to pray with them, and to open to them the Scriptures. He who does faithful work outside of the pulpit will accomplish tenfold more than he who confines his labors to the desk." See White, Testimonies for the Church, 9:124. 
evangelist "will be, to a great extent, a failure."15

The mission of the church is established by the Great Commission (Matt 28:18-20), and also by the Three Angels' Messages (Rev 14:6-12). Ellen White states that the accomplishment of the great work of the third angel's message "must be largely accomplished by persevering, individual effort, by visiting the people in their homes."16 In other words, the work of visitation is indispensible and irreplaceable in fulfilling the Great Commission. In White's words, it is "one of the most effective ways in which light can be communicated." ${ }^{17}$ She also mentions that in a vision of a "great reformatory movement" among God's people, "hundreds and thousands were seen visiting families and opening before them the Word of God." ${ }^{18}$ Thus, visitation, connected with Bible studies, form two important criteria in evangelistic outreach.

Pastors play an important role in leading out in this essential work. Callahan observes that in most effective visitation programs "the pastor has taken a major role in actually doing visitation." 19 This is important because when the pastor is doing regular visitation he or she is also, as Callahan notes, "teaching the congregation, both directly and indirectly, the value of this activity in the life and mission of the congregation..20 This is, nevertheless, a ministry that pertains to both pastor and laity, and a ministry that

${ }^{15}$ White, Evangelism, 440.

${ }^{16}$ White, Welfare Ministry, 97.

${ }^{17}$ Here, Ellen White refers this private and personal effort of visitation and Bible study in the home circle, at the neighbor's fireside, and at the bedside of the sick. See Ibid.

${ }^{18}$ White, Testimonies for the Church, 9:126.

${ }^{19}$ Callahan, 13. 
the pastor must lead out in through training and working with the laity for effective results in soul winning.

\section{Benefits of Visitation}

There are some specific benefits of visitation. According to Ellen White it brings people into the atmosphere of heaven. It "will bring to the workers the bright beams of the Sun of Righteousness, and even the countenance will express the peace that dwells in the soul. . . . If all could see and understand, and be doers of the words of God, what peace, what happiness, what health of body and peace of soul, would be the result.. ${ }^{21}$ In Callahan's view it contributes to church growth. "There is," he writes, "a direct correlation between visitation, mission, and church growth. ... Those churches who substantially engage in visitation and mission are precisely those churches that have the best possibility for growth." ${ }^{22}$ White emphasizes that it also relates to our level of spirituality: "Those who do not take up this work, those who act with the indifference that some have manifested, will soon lose their first love and will begin to censure, criticize, and condemn their own brethren."23

\section{Biblical Examples of Visitation}

The significance of the meaning of "visit" flows throughout the Scriptures.

Visitation speaks clearly of a God who longs to know His people (Gen 3:8, 9), and a God

${ }^{20}$ Callahan, 13.

${ }^{21}$ White, Welfare Ministry, 103.

${ }^{22}$ Callahan, 14.

${ }^{23}$ In this statement Ellen White refers to the work of visiting our neighbors in a friendly way. See White, Welfare Ministry, 78, 79. 
who deeply cares about His people (Jer 23:2-4). Watt writes that "God is a visitor! It is His nature, and it was His mission."24

\section{God the Father Visited}

In Scripture, God's revelation of Himself to humans often takes the form of a visit. He visited Adam and Eve to bring them the good news of salvation (Gen 3:8-15); He visited Abraham to tell him to establish the nation of Israel (Gen 17); He visited Moses to tell him to lead His people out of Egypt (Exod 3:2); He visited Isaiah and gave him insight into the coming of the Christ (Isa 9:6-7; 11:1-9); and He visited Samuel when he was still young (1 Sam 3:1-10).

We also find that He did not neglect the faithful elderly. He visited Moses in the wilderness when he was 80 (Exod 3); He visited John when he was old and lonely on Patmos (Rev 1); and Daniel, through His angels, in the lion's den (Dan 6).

Watt summarizes: "The Old Testament reveals a God who visited His people and changed their lives, and through them the lives of others (e.g., Abraham, Gen 17:1; Moses, Exod 3:10; Joshua, Jos 3:7; Gideon, Judg 6:17). ${ }^{25}$ The first visitation in the Old Testament was God seeking sinners (Gen 3:8, 9). The first in the New Testament was by the wise men to the baby Jesus (Matt 2:1-12); seekers after God. Thus, the purpose of visitation is to bring the truth and salvation to sinners, or to answer their questions about the truth and salvation (cf. John 3:1-15).

When the time had come (Gal 4:4), God visited humanity in a unique way

${ }^{24}$ David Robert Watt, "Empowering the Laity for the Ministry of Visitation" (D.Min. dissertation, Acadia Divinity College, 1999), 25.

${ }^{25}$ Ibid., 27. 
through His son, Jesus. Jesus was the missionary sent by God to visit, seek, and save this world; "For the Son of Man came to seek out and save the lost" (Luke 19:10).

\section{Jesus Visited}

Throughout His ministry Jesus visited a great deal. For example, He visited the home of Zacchaeus, a tax collector, and brought salvation to him and his household (Luke 19:1-10); He visited the home of Peter to bring healing to his mother-in-law (Matt 8:14); He visited the home of the Roman ruler to bring back life to his daughter (Matt 9:23-26); and He visited two grieving men on the road to Emmaus (Luke 24:13-35). He accompanied them, imparted spiritual truth, recognized their hospitality, and deepened their relationship with God. Watt writes that this visit brought "a life-changing blessing to these two men in the Emmaus home (Luke 24:32-35)."26

Ellen White describes visitation as a major part of Jesus' ministry: “Our Saviour went from house to house, healing the sick, comforting the mourners, soothing the afflicted, speaking peace to the disconsolate.,27

Before He sent His twelve disciples to visit what He termed the "lost sheep of the house of Israel" (Matt 10:6), He sent the Gadarene demoniacs, the first missionaries mentioned in the New Testament, to visit their families and testify and glorify God's mercy and His great work (Mark 5:19).

\section{Paul Visited}

The apostle Paul followed closely Jesus' example in visitation. It is recorded that

\footnotetext{
${ }^{26}$ Watt, 33.

${ }^{27}$ White, Gospel Workers, 188.
} 
he taught the truth "publicly and from house to house" (Acts 20:20). White describes Paul's house-to-house work in these words: "He spent much time in house to house labor, thus availing himself of the familiar intercourse of the home circle. He visited the sick and the sorrowing, comforted the afflicted, and lifted up the oppressed." ${ }^{28} \mathrm{He}$ "went from house to house in all humility of mind, and with many tears and temptations." ${ }^{29}$

\section{Visitation Evangelism}

House to house work includes presenting the truth, as White expresses it, "in love and simplicity," "circulating the publications, telling others of the light that has blessed their own souls." 31 The results will be that the visitors will find opportunities for ministry in many lines. They should pray for the sick, and should do all in their power to relieve them from suffering. ${ }^{32}$ Callahan sees visitation as "the art of responsibly helping people with their human hurts and hopes in an active, intentional, seeking-out way,",33 focused "on sharing effective help with the unchurched persons as they seek to live meaningfully and fully in everyday life. ${ }^{.34}$ Knowles characterizes the concept of door-to-door ministry

${ }^{28}$ White, The Acts of the Apostles, 250.

${ }^{29}$ White, Testimonies for the Church, 6:322.

${ }^{30}$ Ellen G. White, Christian Service (Hagerstown, MD: Review and Herald, 2002), 114.

${ }^{31}$ Ibid.

${ }^{32}$ Ibid., 113.

${ }^{33}$ Callahan, 16.

${ }^{34}$ Ibid., 15. 
as "sharing good news, meeting human needs, and putting love into action."35

\section{Five Purposes in Visitation}

Finley outlines five purposes of visitation, which he terms "the five E's of effective visitation." They are: (1) visitation is to establish relationships that cannot be established in the public meeting, (2) visitation is to evaluate interests and determinate when the fruit is ripe, (3) visitation is to educate prospects by answering their questions, (4) visitation is to entertain and disarm the objections that might arise, and (5) visitation is to encourage decisions. ${ }^{36}$ These purposes help the visitation to be more focused, redemptive, and fruitful.

\section{Five Effective Keys to Elderly Visitation}

There are five keys to effective elderly visitation. The first is to convey right attitudes. These attitudes include respect, patient listening, friendliness, smiling, and caring. They will build friendships, help the elderly to trust in those visiting, and lead to acceptance of the gospel message. ${ }^{37}$ Second, bring a gift. This is part of Chinese culture and especially meaningful to the elderly. Gifts convey a message of respect and care to

${ }^{35}$ George E. Knowles, How to Help Your Church Grow (Washington, DC: Review and Herald, 1981), 47.

${ }^{36}$ Mark Finley, Decisions: Persuading People for Christ (Washington, DC: General Conference of Seventh-day Adventists, 1984), 60-65.

${ }^{37}$ This demonstrates that "visitation evangelism" and "friendship evangelism" go hand in hand. This is true because friendship evangelism has much to do with our attitudes toward the elderly. Also, "the concept of door-to-door ministry . . . is that of sharing good news, meeting human needs, and putting love into action." See Knowles, 47. 
them. ${ }^{38}$ Third, bring comfort. Some elderly have painful memories, some are often sick, and some are just lonely. They need comfort, care, and concern. ${ }^{39}$ Fourth, bring your Bible. A pictorial Bible is more suitable for the elderly because some are illiterate and many cannot see the words clearly. Stories about Jesus, His miracles, and personal testimonies will greatly interest the elderly and deeply impress their minds. Fifth, bring blessings. Before leaving their homes, pray for God's blessings to be with the family. "Blessings" have a special connotation in Chinese culture. The elderly like blessings very much, especially those that give peace of mind. They can be asked to pray by repeating sentence by sentence, thus they will learn how to pray, which is the way to obtain God's blessings.

Visitation of the elderly can be routine and/or casual. As Choi points out, the intention is to "help the elderly deepen relationships with themselves, with each other, with the faith community, and with God;",40 it also brings them hope and a meaningful life. ${ }^{41}$ In the Hong Kong venue, the most effective days for elderly visitation are during the Chinese festivals. People are usually in high spirits during these festivals and their minds are subsequently more open and receptive to our message.

${ }^{38} \mathrm{Gifts}$ do not need to be expensive. They might include some biscuits, fruit, some daily necessities, etc.

${ }^{39}$ Choi notes that "when the elderly are in crises, especially hospitalization, they need emergency visits. At that special moment, caregivers may share the senior persons' burdens and listen to their despair and struggles. Having understood the elderly perplexity, caregivers may help them search with patience and faith for meaning and hope from God." See Choi, 172.

${ }^{40}$ Ibid., 160, 161.

${ }^{41}$ 著樂無第一長者霝性關顧的初探與實踐 (A Joyous Golden Age: Exploration and Practice on Spiritual Care for the Older Persons), 39. 
One day, we did caroling to the elderly at that home. I took two children with me and we visited a single elderly man named Cheung Chiu. We found that he was poor, his apartment had a foul odor, and more miserable, he had no bed to sleep in. He slept on the floor with some newspapers covering the ground. The next day, I brought my extra bed to the church and asked two young men to help take it to him. We spent time cleaning his house for him. He felt very happy and his heart was open to listen to the gospel.

We then visited him each week and each time during our visit we studied the Bible with him and he listened very attentively. A few months later he made a decision to be baptized, but he was too weak to get into the baptistry, so our church accepted him as our member by profession of faith. Six months later, he passed away due to a serious illness. We were sad and missed him, but on the other hand, we thanked the Lord that we had the opportunity to share with him the gospel through visitation evangelism.

\section{Principle 2: From Confrontational Evangelism to Friendship Evangelism}

For purposes of this project, confrontational evangelism refers to what is commonly known as "public" evangelism. Evangelistic campaigns traditionally focus on doctrinal views in contrast to some opposing view, thus creating a "confrontation." The classification is not meant to be pejorative. The point is that in terms of elderly evangelism, confrontation is ineffective without additional personal evangelism. On the other hand, public evangelism can be very effective when accompanied by personal evangelism.

\section{Importance of Friendship Evangelism}

Mittelberg and Hybels note that we live in societies rife with distrust of spiritual 
authorities and religious institutions. ${ }^{42}$ At the same time, it is a world filled with lonely people who are starving for the affirmation of a loving touch. ${ }^{43}$ Warren points out that a good friend can make all the difference in this kind of broken, alienated society. "The ministry of love," he says, "touches people at the point of their felt needs."

\section{Meaning of Friendship Evangelism}

Stebbins points out how some definitions of "friend" that highlight its importance. A friend is "a person who knows all about you and loves you anyway" and "one who never gets in the way except when you are on the way down." ${ }^{45}$ Smith employs the concept within a Christian context: "Friends don't let friends miss heaven!" ${ }^{46}$ As far back as Old Testament times, Solomon added yet another dimension, "A friend loves at all times, and a brother is born for adversity" (Prov 17:17). According to Jesus, the greatest friend of all is one who "lays down his life for his friends" (John 15:13).

Jesus set the pattern for friendship evangelism when He spent significant time with so-called sinners. As a result, He was called a "friend" of sinners (Matt 11:19). According to Ellen White, friendship evangelism is precisely what is needed. "By

${ }^{42}$ Mark Mittelberg and Bill Hybels, Building a Contagious Church: Revolutionizing the Way We View and Do Evangelism (Grand Rapids, MI: Zondervan, Willow Creek Resources, 2001), 300.

${ }^{43}$ Warren, 214.

${ }^{44}$ Arthur G. McPhee, Friendship Evangelism: The Caring Way to Share Your Faith (Grand Rapids, MI: Zondervan, 1978), 12.

${ }^{45}$ Tom Stebbins, Evangelism by the Book: Applying First Century Principles to Twenty-First Century Relationships (Camp Hill, PA: Christian Publications, 1995), 2.

${ }^{46}$ Jack R. Smith, Friends Forever: Studies in Relational Evangelism (Atlanta, GA: Home Mission Board, SBC, 1994), 9. 
carrying the truth into the homes of their 'friends' and 'neighbors,' they could do a great work for the Master." ${ }^{, 47}$ The early church used precisely this method: "The believers sought out friends, relatives, and acquaintances, and with hearts overflowing with love, told the story of what Jesus was to them." 48

In a contemporary setting, friendship evangelism can take many forms. Stebbins, for instance, mentions that it may mean "developing meaningful, loving relationships with unchurched people.... To others, the term stands for 'living the life' and 'sharing the love of Jesus' with neighbors. ... Then there are those who see it as inviting friends to their home for dinner, a cookout, or a Bible study in hopes of creating an opportunity to share with them the Good news of Jesus." ${ }^{, 49}$ Overall, whatever ways we do it, friendship evangelism, in McPhee's words, is a "the caring way to share your faith." 50

\section{Biblical Examples of Friendship Evangelism}

In the Bible there are examples of friendship evangelists, some well known and some less known. Jesus, of course, is at the top of the list. He was known as the "friend" of sinners.

\section{The Trinity: Friend of Saints and Sinners}

The Bible tells us that God the Father practices friendship evangelism. He called Abraham, "my friend" (Isa 41:8; 2 Chr 20:7), and even into New Testament times

\footnotetext{
${ }^{47}$ White, Testimonies for the Church, 7:21, emphasis added.

${ }^{48}$ White, Welfare Ministry, 64, 65.

${ }^{49}$ Stebbins, vii.

${ }^{50}$ McPhee, 9.
} 
Abraham was known to be "God's friend" (Jas 2:23). When Jesus came to this world, He befriended the very people whom others despised. For instance, He was called "a friend of tax collectors and sinners" (Matt 11:19; Luke 7:34). The common denominator between Abraham, these tax collectors, and the so-called "sinners" is that they are all said to "trust" in God, a key element of friendship evangelism, which in turn led them to become friends of God. ${ }^{51}$

The Godhead is indeed a friend to both saints and sinners. Jesus represents an outstanding example of a friendship evangelist. He became a friend of sinners so that $\mathrm{He}$ could save His friends from their sins and its penalty. For example, to the woman caught in adultery Jesus was her only friend (John 8:1-11). It was He who stayed by her when everyone else left. Ellen White writes, "Jesus is the friend of sinners, and His heart is touched with their woe. He has all power, both in heaven and on earth; but He respects the means that He has ordained for the enlightenment and salvation of men; He directs sinners to the church, which He has made a channel of light to the world." 52 This is a fitting description of an effective friendship evangelist.

\section{Philip and Nathanael}

Philip, after being called to be a disciple of Jesus, introduced his friend Nathanael to the Messiah (John 1:43-51). Through his influence Nathanael also became a disciple of Jesus. Ellen White remarks that this example "should teach us the importance of personal

\footnotetext{
${ }^{51}$ “The transparent genuineness of Abraham's trust in God is an example all should aspire to emulate." See "James," SDABC 7:523. Also, "trust" is the key element between friends. Smith writes, "A friend is someone you can count on and trust." See J. Smith, Friends Forever: Studies in Relational Evangelism, 9.

${ }^{52}$ White, The Acts of the Apostles, 122.
} 
effort, of making direct appeals to our kindred, friends, and neighbors."

\section{Matthew and His Tax Collector Friends}

Another disciple of Jesus was a tax collector named Matthew. After he became a disciple of Jesus, he was very joyful and wished to bring his former associates to Jesus; to "draw them into the social setting where they'll rub shoulders with committed Christians." ${ }^{\circ 4}$ Accordingly, he held a banquet at his home and invited a large crowd of his tax collector associates and others to join in (Luke 5:27-32). Mittelberg states that "people listen best to new ideas in the context of friendship and in an environment of trust." ${ }^{\text {"S5 }}$ Ellen White further describes the impact of this feast. "At such gatherings as this, not a few were impressed by the Saviour's teaching who did not acknowledge Him until after His ascension. When the Holy Spirit was poured out, and three thousand were converted in a day, there were among them many who first heard the truth at the table of the publicans, and some of these became messengers of the gospel.

\section{Four Lesser Known Friendship Evangelists}

Another incident of friendship evangelism is found in the story in Mark 2:1-12 of Jesus healing a paralytic. While Jesus was preaching in a house, a paralytic who desired to be healed "besought his friends to carry him." "It was so crowded that they could not

\footnotetext{
${ }^{53}$ White, The Desire of Ages, 141.

${ }^{54}$ Mittelberg and Hybels, 294.

${ }^{55}$ Ibid., 291.

${ }^{56}$ Ibid., 274, 275.

${ }^{57}$ White, The Desire of Ages, 264.
} 
get him in. "At his suggestion," White writes, "his friends bore him to the top of the house and, breaking up the roof, let him down at the feet of Jesus." ${ }^{, 58} \mathrm{~A}$ friend in need is a friend indeed. With the help of these four "friendship evangelists," was brought to Jesus and healed. This again demonstrates the power of friendship evangelism in leading people to Christ, and indeed, a "true friend helps at the moment of greatest need. .60

\section{The Importance of Friendship Evangelism in the Four-stage Elderly Evangelism Model}

Friendship evangelism is also known as relational or interpersonal evangelism. ${ }^{61}$ It was "born in the heart of a God who loves people." ${ }^{.62}$ Friendship plays a very important role in personal evangelism.

Win and Charles Arn mention seven reasons why friendship evangelism is one of the most effective means of sharing the gospel: ${ }^{63}(1)$ it provides a natural network for sharing the good news of God's redemptive love, (2) it deals with receptive people, (3) it

${ }^{58}$ White, The Desire of Ages, 268.

${ }^{59}$ Stebbins uses five adjectives to describe these friendship evangelists: compassionate, creative, costly, cooperative, and Christ-centered. See Stebbins, 6-18.

${ }^{60}$ Ibid., 6.

${ }^{61}$ Martin, 53. Also, "evangelism is not an event but a relational process, and God has gifted each of us to play a critical role in drawing men and women to Himself." See William Carr Peel and Walt Larimore, Going Public with Your Faith: Becoming a Spiritual Influence at Work (Grand Rapids, MI: Zondervan, 2003), 30.

${ }^{62}$ Stebbins, 25.

${ }^{63}$ Win Arn and Charles Arn, The Master's Plan for Making Disciples: How Every Christian Can Be an Effective Witness through an Enabling Church (Pasadena, CA: Church Growth Press, 1982), 45-53. 
allows for unhurried and natural sharing of God's love, (4) it provides natural support when the web member comes to Christ, (5) it effectively assimilates new converts into the church, (6) it tends to win entire families, and (7) it provides a constantly enlarging source of new contacts.

\section{Three Important Attitudes in Elderly Friendship Evangelism}

As applied in the Four-stage Elderly Evangelism Model, friendship evangelism stresses three important attitudes in winning the elderly: respect, care, and compassion.

"Respect" is an attitude word. For the elderly mindset it is the most important. When they feel honored and respected they tend to listen to our message.

"Care" is an action word and it means a great deal to the elderly. Even something as simple as providing a cup of water and a bowl of rice and vegetables, giving some small token of appreciation or rendering a small act of help makes a difference.

"Compassion" 64 is a heart word. When we approach the elderly with love and a loving touch, they feel our compassion. When they see our respect, care, and compassion, they will treat us as their friends. This is how friendship evangelism opens an avenue for the gospel in the hearts of the elderly.

I recall an example of how these three words (respect, care, and compassion) are effective in elderly evangelism. One day after lunch I walked around the park to see if any elderly members of our social center were sitting there and found an elderly lady

${ }^{64}$ Samaan has a good explanation of compassion, "Compassion comes from the Latin term compati, which also stems from com, 'with' or 'together,' and pati, 'to suffer.' And the combined literal meaning is 'suffering with,' or 'suffering together.' It is sharing the suffering with the victims, and being passionately moved to help them out of their difficulty." See Philip G. Samaan, Christ's Way of Reaching People (Hagerstown, MD: Review and Herald, 1990), 56. 
ninety-two years old sitting there. I walked over and respectfully greeted her. I then asked what she was doing there. She replied that she was drying her blanket. When I looked at it, it was dirty and torn. I felt very sad. The next day I brought her one of my extra blankets. She looked at me and said, "Why are you so good and care about me?" I answered, "I just follow Jesus' example." She then asked, "Who is Jesus?" When the opportunity came, I shared the Bible with her. Later on, several of us would befriend her by sending her a lunch every Sabbath afternoon. She was so touched. Soon we were able to give her Bible studies. A few months later she was baptized. I noticed and realized that there is great power in winning the elderly when we respect, care, and love them.

\section{Principle 3: From Chinese Festivals to Celebration and Feast}

Chinese festivals are very important to the elderly. They bring back many memories and culture relevance to them. In terms of evangelistic methodology, Jesus set an example when He made use of the Jewish festivals to share the gospel. White comments: "He attended the great yearly festivals of the nation, and to the multitude absorbed in outward ceremony He spoke of heavenly things, bringing eternity within their view."

There are many traditional Chinese festivals. They are a time of enjoyment, getting together, celebration and feasting. In the Four-stage Elderly Evangelism Model festivals are made use of as golden opportunities to share the gospel with the elderly.

\footnotetext{
${ }^{65}$ White, The Ministry of Healing, 22, 23.
} 
Usually after the Sabbath sermon we have a feast together to celebrate the joy we have in Jesus Christ, and many elderly attend. ${ }^{66}$

The idea here is to incorporate culturally-relevant competent programs as a mean of evangelism. If the programs are people-friendly, culturally-relevant and well done, significant crowds could be attracted to Christ. There are some major occasions for these kinds programs such as Chinese festivals, mothers and fathers day, and other days that are meaningful to the elderly. These occasions are deliberately planned as joyful, yet spiritual, days of celebrating and having feasts.

\section{Bringing Crowds to Christ}

Friendship evangelism applies to large audiences and crowds as well as to individual contacts. Stebbins writes, "The church needs to use its crowds creatively to bring individuals to Christ. Yes, people are won to Christ through one-to-one contact. But friendship evangelism extends to the crowds, too." ${ }^{.67}$ Warren explains the difference between a crowd and a church as "a crowd is not a church. But to grow a larger church you must first attract a crowd." 68

The Bible records a number of experiences with crowds. Jesus, for instance, passed through Jericho on one occasion and a "crowd" was drawn to Him (Luke

${ }^{66}$ In the Hong Kong setting, a "feast" is what is often termed a "fellowship meal" or a "potluck" in other cultural settings. In the Four-stage Elderly Evangelism Model, however, it includes much more. During some national festivals and once a month after the Sabbath service, we will have a big meal-feast. We usually prepare 20 some courses of food and serve each elderly person. About 80 elderly, 20 young people, and 20 kids and adults join this monthly feast.

${ }^{67}$ Stebbins, 234.

${ }^{68}$ Warren, 253. 
19:1-10). For instance, the miracle of the resurrection of Lazarus subsequently drew a large crowd. ${ }^{69}$ Jesus' fame spread and among the crowds was a tax collector attracted by Jesus, partly because of His spirit of hospitality. ${ }^{70}$ The tax collector's thinking was that since Jesus already had a disciple who was a tax collector, maybe He would also accept him. Jesus surprised him by informing him that He planned to stay at his home. This is an experience that highlights the importance of hospitality. Some people opposed Jesus' association with "sinners" (Luke 19:7), but it was precisely His purpose and intention to be a friend of sinners. In this case, God used a crowd to draw a particular sinner to the Savior. $^{71}$

Jesus attracted large crowds (Matt 4:25). Warren gives three reasons why He attracted these crowds: (1) because He loved them (Matt 9:36), (2) He met their needs (Matt 15:30; Luke 6:17, 18; John 6:2), and (3) He taught them in interesting and practical ways (Matt 13:34; Mark 10:1; 12:37). ${ }^{72}$ As noted previously, these same elements are woven into the principles of this project. A loving touch and care for the elderly is done through friendship evangelism; we discover and meet their needs through visitation,

${ }^{69}$ Ellen White explains the reason why the crowd came to see Jesus, "It was known that the Galilean Rabbi who had so lately brought Lazarus to life was in the throng. ... The multitudes were eager to do Him homage." See White, The Desire of Ages, 552.

${ }^{70}$ c'Zacchaeus had heard of Jesus. The report of One who had borne Himself with kindness and courtesy toward the proscribed classes had spread far and wide." See Ibid., 553.

${ }^{71}$ Stebbins observes how people naturally follow a crowd, "Everyone is born with an inquisitive eagerness to see and hear that which is attracting the interest of othersespecially large numbers of others. ... Large numbers of people create large portions of curiosity. That curiosity, in turn, draws people almost beyond their control." See Stebbins, 234.

${ }^{72}$ See Warren, 208. 
attract them through to our practical culturally-relevant, seeker-sensitive programs, and interest them through dynamic worship. To summarize their use: Visitation means going to the people. Competent programs and dynamic worship mean attracting people to come to us. Warren summarizes these principles: "To believers, Jesus says, 'Go! But to the lost world, Jesus says, 'Come!',73

\section{Hospitality}

The initial impression guests experience in their visit to the church is vitally important. ${ }^{74}$ The Bible specifically informs that early church leaders like the apostle Paul welcomed visitors: "For two whole years Paul stayed there in his own rented house and welcomed all who came to see him" (Acts 28:30). McIntosh writes that the importance of first impressions is the reason why growing churches, in his words, "spend a significant amount of time getting ready for their company—visitors.... These churches believe they have only one chance to make a first impression, and they want the visitor to experience a friendly welcome. ${ }^{, 75}$ These churches always try to create a welcoming environment for visitors.

"Hospitality" is the English translation of philoxenia in Greek. It literally means "love of strangers," from which we get "entertainment of strangers." It was early regarded as one of the important Christian virtues (see 1 Tim 3:2; Titus 1:8; Heb 13:2; 1

${ }^{73}$ Warren, 235.

${ }^{74}$ Warren says "visitors have already formed an opinion about your church within the first ten minutes after they arrive." See Ibid., 257.

${ }^{75}$ Gary McIntosh, Beyond the First Visit: The Complete Guide to Connecting Guests to Your Church (Grand Rapids, MI: Baker Books, 2006), 7-8. 
Pet 4:9). ${ }^{76}$ In the OT, it was "a demonstration of faithfulness to God (Job 31:32; Isa 58:7). ${ }^{, 77}$ In the New Testament, Huggins notes, there are seven direct references in the NRSV to "hospitality" that comprise "reports of or encouragements to Christians to be hospitable, not just with one another, but to everyone." writes: "When we extend our hand of welcome to visitors, we are extending God's hand of grace., 79

High Quality and Culturally-relevant

The excellence of the programs is seen in their quality and competence as well as in the loving and caring attitudes of the pastors and church members. All of this requires hard work done intelligently. An overabundance of programs will wear out the leaders and the members. Callahan suggests that usually two or three competent programs a year are sufficient. ${ }^{80}$

These qualities inspire and draw people to God. Solomon says, "Whatever your hand finds to do, do it with all your might" (Eccl 9:10). That implies presenting top quality programs. Quality in this case is more important than quantity. "People from the community," Callahan writes, "are attracted to a congregation's program precisely

76،"Romans," SDABC, 6:622.

${ }^{77}$ J. D. Douglas and N. Hillyer, The Illustrated Bible Dictionary, 3 vols. (Wheaton, IL: Tyndale House, 1980), s.v. "Hospitality."

${ }^{78}$ The seven direct references are found in Acts $28: 7 ; 1$ Tim 3:2, 5:10; Titus 1:8; 1 Pet 4:9; Rom 12:13; Heb 13:2. See John R. Huggins, "Revitalizing Pastoral Visitation" (D.Min. dissertation, United Theological Seminary, 1998), 22.

\footnotetext{
${ }^{79}$ McIntosh, 12.

${ }^{80}$ Callahan, 64.
} 
because of the quality of what it shares with those who participate."81

There are biblical examples of culturally-relevant programs. Paul writes about cultural relevance in his letter to the church in Corinth:

Though I am free and belong to no man, I make myself a slave to everyone, to win as many as possible. To the Jews I became like a Jew, to win the Jews. To those under the law I became like one under the law (though I myself am not under the law), so as to win those under the law. To those not having the law I became like one not having the law (though I am not free from God's law but am under Christ's law), so as to win those not having the law. To the weak I became weak, to win the weak. I have become all things to all men so that by all possible means I might save some. I do all this for the sake of the gospel, that I may share in its blessings (1 Cor 9:19-23).

Paul attempts to adapt to the local culture, to "comply with the habits, customs, and opinions of others as far as possible, without compromising principle;",82 Ellen White supports this concept, "The servants of Christ should accommodate themselves to the varied conditions of the people. . . . Labor will have to be varied to meet the people where they are. ${ }^{83}$ This is cultural relevance, ${ }^{84}$ and seeker-sensitive ministry.

\section{Culturally-Relevant Programs}

The Four-stage Elderly Evangelism Model includes the following culturallyrelevant methodologies.

${ }^{81}$ Callahan, 66.

82"1 Corinthians," The Seventh-day Adventist Bible Commentary, ed. Francis D. Nichol (Washington, DC: Review and Herald, 1978), 6:733.

${ }^{83}$ White, Testimonies for the Church, 2:673.

${ }^{84}$ Burrill also agrees: "Paul's strategy was to make the gospel culturally relevant to every group he attempted to teach." See Burrill, 35. Also, "Paul recognized that the form (not the content!) had to change in order to get results. He noticed that he had to make changes as he went to different groups so that the Gospel could get through to his hearers." See Kent R. Hunter, Foundations for Church Growth: Biblical Basics for the Local Church (Corunna, IN: Church Growth Center, 1994), 121. 


\section{Gospel Tea Party}

In Chinese culture tea preparation and tea-drinking is regarded as a form of culture and as a form of art, as well as an avenue of interpersonal interaction. To each Chinese family, tea is one of the seven "essentials" in their daily life: fuel, rice, oil, salt, soy-sauce, vinegar, and tea. At a wedding ceremony, the parents-in-law drink the "bridal tea." Offering tea to a visitor is a form of welcome and respect. ${ }^{85}$

In view of the importance of tea in Chinese culture, as an element of the Fourstage Elderly Evangelism Model we introduced the "Gospel Tea Party" during the afternoon tea time. Its contents are drinks substituted for tea, songs, and a gospel message.

\section{Senior Citizen's Day}

Beginning in 1993 the Hong Kong Government designated the third Sunday of November as "Senior Citizen's Day." ${ }^{86}$ Its purpose is to promote a culture of "respecting, loving, and honoring the elderly." This provides an excellent opportunity to celebrate with the elderly. This is their day and they feel honored when it is recognized.

\section{Mother's Day and Father's Day}

Another mechanism for recognizing and honoring filial piety is programs organized for Mother's Day and Father's Day. These usually produce overflow attendance. On these days gifts are provided for the elderly, various social programs and

\footnotetext{
${ }^{85}$ 雷子健, 人人佈道有妙法 (Everybody Ought to Know); 宣教與文化 (Mission and Culture）（香港: 迎新有限公司, 2004), 1.

${ }^{86}$ The first "Festival for the Elderly" was organized in 1979 by the Council of Social Welfare Service and it was later recognized by the Hong Kong Government as "Senior Citizen's Day."
} 
a special evening banquet is organized at a restaurant for them and their families.

We noticed that the Mother's Day program was one of the most welcome programs among all because 77 percent of the elderly members were women. Our program was usually held on Sabbath morning and on the same evening. In the morning worship program, we would give a flower and a gift to every mother and grandmother. We would have games, a lucky draw, and singing, etc., in the evening.

In the sermon, we showed appreciation for a lot of the hard work they did in raising up their children. Some of our young people would share their testimonies and give flowers to their mothers and others. After the worship we would have a big banquet at the church, usually twenty or more courses of food were served. They enjoyed and liked it so much. On the same evening, we would have another banquet in a restaurant, usually there were twelve tables set for twelve people. It was like a wedding banquet; the elderly liked it so much. We put on skits, sang to them, and shared a word of appreciation to the mothers-it was just an unforgettable evening for the elderly.

\section{Principle 4: From Worshipping Forefathers to Worshipping the Heavenly Father}

As noted, many elderly are ancestor worshippers. The main background of this is filial piety. By introducing our heavenly Father as the father of all fathers, we help them worship the Creator rather than created beings. In the Four-stage Elderly Evangelism Model this stage is designed to incorporate dynamic worship as a means of evangelism.

The Importance of Worship

The general word for worship in Hebrew is shachah, meaning "to bow down," "to 
worship," and in Greek, latreū̄, meaning "to serve." ${ }^{, 87}$ In Rev 22:3, latreuō is translated to "to serve," "to worship," "to minister." ${ }^{, 88}$ Vine defines this word as "to render religious service or homage. $\$ 89$

A biblical example is the prophet Isaiah worshiping in the temple (Isa 6:1-8). He sees a vision of God, hears the angels sing, confesses his sins, and then responds to God's call for service (v. 8). Kidder writes, "True worship will always result in service. We cannot enter into the worship of the Almighty without afterward departing into the world to serve." ${ }^{90}$ True worship will create excitement and enhance spirituality; as a result, believers are more "inclined to do ministry and evangelism." senses the presence of God and his or her faith is nourished, they can, in Goebel's words, "become transformed into effective witnesses." "92

\section{Dynamic Worship}

Barna's studies on highly effective churches furnish some insights on how to make worship more dynamic. Dynamic worship services use one or more approaches to

${ }^{87}$ Seventh-day Adventist Bible Dictionary, s.v. "Worship."

${ }^{88}$ "Revelation," Seventh-day Adventist Bible Commentary, ed. Francis D. Nichol (Washington, DC: Review and Herald, 1978), 7:895.

${ }^{89}$ Vine, s.v. "Worship."

${ }^{90}$ S. Joseph Kidder, Majesty: Experiencing Authentic Worship (Hagerstown, MD: Review and Herald Publishing Association, 2009), 13.

${ }^{91}$ Ibid., 9.

${ }^{92}$ Joan E. Goebel, "Church Revitalization Through Worship Evangelism" (D.Min. dissertation, University of Dubuque Theological Seminary, 2002), 9. 
educate the congregation about worship: ${ }^{93}$ (1) establish that worship is about our focusing on God, not God focusing on us; (2) provide adults with a compelling reason to engage in worship; (3) explain how worship is both an attitude and an action; (4) facilitate the ability to become intimate with God; (5) encourage people to come to the worship event prepared to worship, and (6) place the burden of success in worship upon the individual, not the institution.

\section{Worship His Greatness}

The best way to educate congregations and help them prepare for worship is to study the heavenly worship model of how the heavenly beings worship God.

John Fowler describes the heavenly worship of four aspects of God: His holiness, His eternity, His activity, and His authority. ${ }^{94}$ First, worship begins by acknowledging that God is holy. The four creatures praise God day and night by singing, "Holy, holy, holy, is the Lord God Almighty" (Rev 4:8). Second, worship recognizes God as eternal, "Who was, and is, and is to come" (Rev 4:8). Third, worship points to the activity of God, "You are worthy, our Lord and God, to receive glory and honor and power, for you created all things, and by your will they were created and have their being" (Rev 4:11). It declares that God is the creator, provider, and also redeemer. His redemptive activity "forms a large part of praise in worship... The throne is a redemptive throne, a victorious throne. The elder with white garments of righteousness and crowns of victory

\footnotetext{
${ }^{93}$ Barna, The Habits of Highly Effective Churches, 89-92.

${ }^{94}$ John M. Fowler, “Worship's True Motive," Ministry, November 1993, 4, 5.
} 
are symbolic of that redemptive activity of God." ${ }^{.95}$ Fourth, worship acknowledges God's authority. His "throne" signifies authority.

This scene of heavenly worship, Fowler adds, directs people to "the greatness of God"--He is holy, eternal sovereign, creator, provider, and redeemer, thus, it forms the purpose of worship, to focus on the greatness of God. ${ }^{96}$ Thus, worship "is about being caught up in the majesty and wonder and awe of God."97 The psalmist says, "For the LORD is the great God, the great King above all gods" (Ps 95:3). Ellen White writes, "True reverence for God is inspired by a sense of His infinite greatness and a realization of His presence." 98

\section{Worship with Gladness}

Worship is our response to God's nature and action; that He has made us (Ps 100:3) and He is good, merciful, and faithful (Ps 100:5). The psalmist calls us to "Serve the LORD with gladness; come before His presence with singing" (Ps 100:2, NKJV). Here is the true heart in worship: it is: (1) humble_-"serves," (2) pious_-"serve the Lord," (3) active - “serves," (4) consequently joyful_-"with gladness," and (5) reverent— "before His presence." 99

${ }^{95}$ Fowler, 5.

${ }^{96}$ This understanding helps to educate the congregation on approaches 1 to 4 in Barna's list.

${ }^{97}$ Kidder, Education for Worship, 8.

${ }^{98}$ White, Prophets and Kings, 48. This understanding helps to educate the congregation on approaches 5 and 6 in Barna's list.

${ }^{99}$ For purposes of the Four-stage Elderly Evangelism Model I have added "reverent" based on a comment by Spurgeon. See C. H. Spurgeon, The Treasury of David: Containing an Original Exposition of the Book of Psalms; a Collection of 
Gladness is the keynote of the psalm, ${ }^{100}$ Spurgeon comments, "He is our Lord, and therefore $\mathrm{He}$ is to be served; He is our gracious Lord, and therefore He to be served with joy."101

The psalmist continues: "Enter into His gates with thanksgiving, and into His courts with praise" (Ps 100:4). Ellen White comments about thanksgiving and praise, "The melody of praise is the atmosphere of heaven; and when heaven comes in touch with the earth, there is music and song-'thanksgiving, and the voice of melody.' Isaiah 51:3 . . Great have been the blessings received by men in response to songs of praise. 102

These sources present us with two elements of worship. First, worship God with gladness in our singing; second, worship with thanksgiving and praise. ${ }^{103}$ The psalmist says, "Whoever offers praise glorifies Me" (Ps 50:23, NKJV). This worship offers our songs of praise to God. ${ }^{104}$ This worship will lift us up to heaven. In Ellen White's words,

Illustrative Extracts from the Whole Range of Literature; a Series of Homiletical Hints Upon Almost Every Verse; and Lists of Writers Upon Each Psalm, 3 vols. (Peabody, MA: Hendrickson Publishers, 19--), 2:238.

100“"Psalms," SDABC, 3:856.

${ }^{101}$ Spurgeon, 2:233.

${ }^{102}$ Ellen G. White, Education (Mountain View, CA: Pacific Press, 1952), 161, 162 , italics added.

${ }^{103}$ Joseph Kidder describes praise as "preoccupied with who God is and what He has done. It focuses on both His incomparable character and His wondrous acts on behalf on His children. . . . Praise is based upon God's greatness. . . Praise manifests itself in many ways but mainly in singing and prayer." See S. Joseph Kidder, "Education for Worship in the East Wenatchee Seventh-day Adventist Church," 63.

${ }^{104}$ Singing can "inspire and elevate the souls" and awake "gratitude to God." See White, Patriarchs and Prophets, 594; Idem., Education, 167. 
"The soul may ascend nearer heaven on the wings of praise. God is worshiped with song and music in the courts above, and as we express our gratitude we are approximating to the worship of the heavenly hosts." 105

Thus, Timothy Robnett observes that "to worship God draws one's affections to a higher level." 106 In other words, "worship with gladness" is singing songs of praise with a heart of thanksgiving for "the LORD is great and greatly to be praised" (Ps 96:4, NKJV).

\section{Worship with Gray Hair}

The Four-stage Elderly Evangelism Model deems this kind of worship as involving everyone, including the elderly. "Young men and maidens, old men and children. Let them praise the name of the LORD" (Ps 148:12, italics added).

Ellen White suggests that acceptable worship to God "should be made intensely interesting ... and attractive." ${ }^{107}$ Callahan adds, "Worship is dynamic whenever the service stirs and inspires the people who participate in it." ${ }^{\text {108 }}$ This is made possible by the joyful praise of songs ${ }^{109}$ and interesting preaching. ${ }^{110}$

${ }^{105}$ Ellen G. White, Steps to Christ (Mountain View, CA: Pacific Press, 1956), 104.

${ }^{106}$ Timothy L. Robnett, "A Trinitarian Theology of Worship and Preaching with Implications for the Family Life Cycle" (D.Min. dissertation, Fuller Theological Seminary, 1994), 79.

${ }^{107}$ White, Testimonies for the Church, 5:609.

${ }^{108}$ Callahan, 24.

${ }^{109}$ Ellen White suggests there be much praise and prayer. "Much of the public worship of God consists of praise and prayer, and every follower of Christ should engage in this worship." See Ellen G. White, The Pastoral Ministry (Silver Spring, MD:

Ministerial Association, General Conference of Seventh-day Adventists, 1995), 177.

${ }^{110}$ The preaching has to impress the worshippers "with the elevated, ennobling, character of the truth and its power to cleanse the heart." See White, Evangelism, 207. 
These considerations lead to the development of worship within the Four-stage Elderly Evangelism Model as including warm friendship, joyful music, and worship-style preaching.

\section{Warm Friendship in the Worship Environment}

Kidder is correct in saying that "relationship becomes not only important in bringing people to the Lord, but also in keeping them in the Lord and the church."111 Once they come to the church, the first ten minutes are crucial. During those minutes visitors will decide if they will come back or not. ${ }^{112}$ The first impression that they get within those first ten minutes is really about the warm friendship and the music, all of which occur before the pastor preaches. What is of prime importance is the warmth that the visitors experience in their interaction with greeters, ushers, and other leaders of the worship service. ${ }^{113}$ When the worshipers feel the warmth of that friendship, in Callahan's words, "they leave a service surprised and profoundly grateful for the time they have shared one with another."114

Greeting and shaking hands with senior citizens before and after the worship service make them feel the warmth of the church. Also, a little token of appreciation

${ }^{111}$ S. Joseph Kidder, "The Power of Relationships in Evangelism," Ministry, July 2008, 11. Barna's research shows that the emphasis on relationships has become increasingly important in attracting the unchurched to attend a church. This pre-existing relationship with a church member helps the visitor feel comfortable and relationally tied in to the church. See Barna, The Habits of Highly Effective Churches, 79, 80.

\footnotetext{
${ }^{112}$ Warren, 257.

${ }^{113}$ Callahan, 25.

${ }^{114}$ Ibid.
} 
given to them as they leave helps them experience our friendship and care.

\section{Joyful Music}

Singing is an important part of the worship of God. ${ }^{115}$ Music plays a very important role in worship. ${ }^{116}$ Barna says that "highly effective churches typically incorporate at least 20 minutes of uninterrupted worship music into their services."117 Callahan suggests that it should constitute 40 percent of a dynamic worship service. ${ }^{118}$ Good planning, ${ }^{119}$ practicing, and quality of the music will enhance the worship service. Warren opines that "music sets the mood of your service."120 Aristotle adds, "Music has the power to shape character," 121 and is used "for the heart, not for the art."122

Choi has this to say about the music for the elderly in Hong Kong: "Music is an important tool in worship. The Hong Kong elderly did not grow up with Christian music. In order to show respect to the elderly, music ministry leaders must consider the elderly

${ }^{115}$ White, Evangelism, 506.

${ }^{116}$ Music helps "focus people's attention on God and on the act of worship; calm people down and soften their hearts toward God; facilitate intimacy with God, and stir their souls." See Barna, The Habits of Highly Effective Churches, 97, 98.

${ }^{117}$ Ibid., 98.

${ }^{118}$ Callahan, 27.

${ }^{119}$ Ellen White says, "Many want to do things after their own style; they object to consultation, and are impatient under leadership. Well-matured plans are needed in the service of God." See White, Evangelism, 505.

${ }^{120}$ Warren, 286.

${ }^{121}$ Ibid., 279.

${ }^{122}$ Ibid., 287. 
special needs. ${ }^{.123}$ In our worship services for the elderly in our center we use what we call "gospel opera songs." $" 124$ These familiar songs, rewritten with gospel lyrics, appeal to the elderly.

\section{Worship Preaching}

Rick Warren comments that "there is so much bad news in the world, people need a place to hear good news." ${ }^{225}$ Good news is indeed found in Jesus Christ, and Him crucified. That good news brings comfort and hope. Goebel says "It is important, even crucial, that the worship service be used as a tool of evangelism in the churches for today." ${ }^{26}$ Sally Morgenthaler notes how evangelism can take place in worship: "It (worship evangelism) happens in two ways: first, as unbelievers hear the truth about God (through worship songs, prayers, communion, baptism, scripture, testimonies, dramas, and so on); and second — and more importantly - as they observe the real relationship between worshipers and God." ${ }^{127}$ Andy and Sally Langford affirm that "worship is the primary evangelistic act of the church."128

There are five key ideas about preaching to the elderly:

${ }^{123}$ Choi, 181. Also, Warren says we must match our music to the kind of people God wants our church to reach, see Warren, 280.

${ }^{124}$ All the elderly in Hong Kong are familiar with "opera songs." We have songs written with gospel lyrics while retaining the original tunes and melodies.

${ }^{125}$ Warren, 271.

${ }^{126}$ Goebel, 15 .

${ }^{127}$ Sally Morgenthaler, Worship Evangelism: Inviting Unbelievers into the Presence of God (Grand Rapids, MI: Zondervan Publishing House, 1995), 12.

${ }^{128}$ Andy Langford and Sally Overby Langford, Worship and Evangelism (Nashville, TN: Discipleship Resources, 1989), xi. 
1. The sermons should be short, simple, clear, and "easily followed and make sense," 129

2. The sermons should be evangelistic. Most elderly are nonbelievers and sermons should always present Christ and Him crucified as the foundation, ${ }^{130}$

3. Sermons should be "hopeful and helpful in the midst of the pain, suffering, and injustice present in the world." 131 This is particularly important for the elderly. They have experienced many trials in life and greatly need messages of peace of mind and hope,

4. Designed to get their responses by asking questions and dialoguing with them, ${ }^{132}$

5. Appeals should be made after each sermon. This is very important because time for the elderly is short. Some may never come to a service again. ${ }^{133}$ Fowler makes the

${ }^{129}$ See Callahan, 28. Also, Ellen White says, “The true, honest expression of a son or daughter of God, spoken in natural simplicity, has power to unbolt the door to hearts that have long been closed against Christ and His love." See White, Christ's Object Lessons, 232.

${ }^{130}$ White, Gospel Workers, 158.

${ }^{131}$ Callahan, 29.

${ }^{132}$ Ellen White has a suggestion for overcoming inattention, "If, instead of preaching to them, the speaker would try to teach them, speaking in a conversational tone and asking them questions, their minds would be aroused to activity, and they would be able more clearly to comprehend the words spoken." This is important to elderly preaching, as many feel tired and sleep easily, and you will know how much they understand the message by asking and dialoging. See White, Gospel Workers, 167.

133،In every discourse fervent appeals should be made to the people to forsake their sins and turn to Christ." Ibid., 159. 
point that "worship is incomplete without the cross," 134 and that "true worship is God reseen and man remade."135

Our young people came half an hour early to prepare, practice, set up, and more importantly, pray together. We welcomed the elderly as they came into the service. Many of the young people led out in the song service with gospel opera songs and other hymns. In the midst of singing, the young people would go and shake hands with all the elderly, which made them feel very welcome and respected. Later, we had the young people praying with the elderly in groups. They prayed for their health, peace, and protection.

After the sermon, when the elderly left the church, they would receive a gift. All the young people stood on both sides of the door to shake hands with them and to ask them to come again the following week. This was done in a joyful atmosphere. Respect and happy moments were what we communicated to the elderly when they came in and when they left.

\section{Summary}

Four principles were used in the Four-stage Elderly Evangelism Model. They are visitation evangelism, friendship evangelism, culturally-relevant competent programs, and dynamic worship. These principles are based on the theoretical foundations of elderly evangelism presented in chapters 2 and 3. Visitation and friendship evangelism are defined as "finding those who are looking for God and keeping those who are looking for

\footnotetext{
${ }^{134}$ Fowler, 5.

${ }^{135}$ R. A. Anderson, "Our Worship of God," The Ministry, October 1958, 50.
} 
relationships." ${ }^{\text {136 }}$ Through friendship evangelism seekers are brought to the church for programs and worship. Culturally-relevant competent programs are designed to draw the crowds to Jesus, and dynamic worship is designed to help them experience the joy of worship in God's presence. The first two principles form the "going" part of the model, seeking the lost and making friends with them. The last two principles form the "coming" part of the model: attracting them and keeping them in the church.

Dynamic worship is the high point of the model. It brings the blessings of God, for $\mathrm{He}$ "expects to be with them, to bless and comfort them, filling their hearts with joy and love. ${ }^{n 137}$ The greatest blessing of all is not just for this life, but also for the life to come-in eternity!

${ }^{136}$ Gary McIntosh and Glen Martin, Finding Them, Keeping Them: Effective Strategies for Evangelism and Assimilation in the Local Church (Nashville, TN: Broadman Press, 1992), 7.

${ }^{137}$ White, Steps to Christ, 103. 


\section{CHAPTER 5}

\section{DESCRIPTION AND EVALUATION OF THE PROJECT}

The purpose of this chapter is two-fold: (1) describe the initial development of the Four-stage Elderly Evangelism Model and (2) describe the implementation process of the model.

\section{Development of the Four-stage Elderly Evangelism Model}

I believe that both experience and theory are necessary for a successful working model. Thus, the development of the Four-stage Elderly Evangelism Model was a twostage process: (1) experiential, and (2) theoretical.

\section{Experiential}

God has given me a rich background in elderly ministry. For fifteen years, ever since I graduated from college, I have worked at the Siu Sai Wan Church of Seventh-day Adventists. This church operates the Elderly Center previously described. The context of the Center has provided me with an abundance of encounters and experiences in working with the elderly.

In addition, I can trace God's training and providing me with modeling experiences in the key elements of this project back in the country where I was born, Vietnam. In the times prior to the Vietnam liberation in 1975 we lived in a traditional, huge Chinese family of over twenty people living lovingly and harmoniously under the 
same roof - grandparents, parents, uncles, aunties, brothers, and sisters. My father was a teacher. He taught us to be respectful to all older generations. At home I learned how to respect the elderly. My mum lovingly took care of the twenty some members of the family. That is where I learned how to care and love. My parent's examples of filial piety deeply influenced all of us. They shaped our core values to the very depths of our souls. This influenced my personal attitudes on treating the elderly with respect, love, and caring.

Later, after the liberation, I became an Adventist, and we had a very strong visitation program in our church. We visited the guests and church members very often. This served as a model for me on how to lead out in a visitation program as outlined in this project. In the development of the Four-stage Elderly Evangelism Model I observed the elderly in the Center living lonely lives and dying hopelessly one by one. That sickened my heart and I purposefully wanted to make the visitation program both vibrantly and successfully done.

Life after the liberation in Vietnam was very hard. As a result, however, the relationships, friendships, and brotherly love in the church grew even stronger. I was impressed that this kind of friendship helps people to get through all kinds of trials and difficulties. Within this context of these hardships I learned a lot about attitudes toward people. The experience served as a model when implementing the friendship evangelism component in this project.

Another key element I learned about was worship. Before the country was liberated, only the rich people could go to the best music schools. After the liberation, everyone had that opportunity, young and old, rich and poor. I enrolled in the best music 
school in the country and studied under first-class teachers who had been trained in the former Soviet Union. The Chinese church had a 50-voice choir that provided us with abundant opportunities for practicing, leading, and conducting choir and other music programs. Because of these factors, our teachers paid particular attention to us and spent extra time teaching and training us. This precious experience modeled for me how to lead out in vibrant music programs, and especially in the "Gospel Opera Songs" in our "Dynamic Worship" segment.

The Siu Sai Wan Elderly Center runs many different programs and activities. While helping there I carefully observed and learned. This prepared me to lead out in the Culturally-relevant Competent Programs component of the Four-stage Elderly Evangelism Model.

Thus, my personal background gave me a rich experience in the fundamentals of respect, love, care, filial piety, visitation, friendship, and worship which became the key components of the model.

\section{Theoretical}

God provided me with the experiential background for personal development of the skills and experiences necessary for developing this project on elderly evangelism. What I lacked was the theoretical aspect. After carefully researching Christian literature, I found a number of sources dealing with elderly ministry, but very little on elderly evangelism. Moreover, nearly all these sources were developed within an American context.

In my investigation I found three helpful doctoral dissertations. The first is Choi's "A Proposed Model of Christian Pastoral Care with the Chinese Elderly in Hong Kong." 
This dissertation provided key insights on the concept of filial piety and the challenges facing the elderly in Hong Kong. The second dissertation, Ng's "Religion, Culture, and Modernity: Some Missiological Implications of the Process of Secularization in East Asia," provided key insights on the traditional Chinese worldview. The third was Smith's "Chinese Ancestor Practices and Christianity: Toward a Variable Contextualization of Christian Ethics in a Hong Kong Setting." His research indicates that ancestor worship in Hong Kong is less religiously and more socially and ethnically motivated. This perspective helped as we developed ways and means of sharing the gospel with the elderly.

Dr. Joseph Kidder's ideas on formulating a strategy were extremely helpful in the development of this project. He visited my church, preached, and conducted a training seminar for our young people. More importantly, he challenged me to search for some elderly conversion examples in the Bible. In the beginning this was difficult, because I had no clue about what to look for. God, nevertheless, was leading step by step and I eventually found three pertinent examples in the Bible that provided some key insights on elderly evangelism. Dr. Kidder also introduced me to Callahan's Twelve Keys to an Effective Church, which provided me some concepts and principles for the development of the four stages of this project.

God has led me step by step in developing this elderly evangelism model: through my own family, the church, the Elderly Center, and my professors - from experience to theoretical.

\section{Implementation of the Four-stage Elderly Evangelism Model}

The four stages of the model are: (1) From House to House, (2) From 
Confrontation Evangelism to Friendship Evangelism, (3) From Chinese Festivals to Celebration and Feast, and (4) From Worshipping Forefather to Worshipping the Heavenly Father. These four stages are built on a foundation composed of four principles: (1) visitation evangelism, (2) friendship evangelism, (3) cultural relevant competent programs, and (4) dynamic worship.

The implementation of the model was done at the Siu Sai Wan Social Center for the Elderly in Hong Kong. The human resources for the project were mainly the pastor (myself) and a core of church members who are faithful, active, and who would participate in the events. We also had the help of some staff and elderly members ${ }^{1}$ of the Center. The target audience was the elderly members of the social center who were over sixty years of age.

My husband, Terry, and I formed the leadership team to lead the core group members to do the ministries. As we led out in the ministries and modeled them by example and encouragement, they would follow. Once my conference officers asked me why my church members would serve so enthusiastically; I told them that I did it by example. Sometime later I asked my members the same question. They said it was because they saw our examples and passion in evangelism, so they were inspired and followed. Ellen White concurs that soul winning ministers produce soul winning members. She writes: "When the church sees that the ministers are all aglow with the

${ }^{1}$ Some elderly members of the center were really helpful. As Gentzler and Clingan say, "While younger women and men may be engaged in raising a family or building a career, older adults have the time to serve the needs of their congregation and community." See Richard H. Gentzler and Donald F. Clingan, Aging: God's Challenge to Church \& Synagogue (Nashville, TN: Discipleship Resources, 1996), 24. 
spirit of the work, that they feel deeply the force of the truth, and are seeking to bring others to the knowledge of it, it will put new life and vigor into them. Their hearts will be stirred to do what they can to aid in the work."

We also tried to make evangelism easy for the members to start and continue. Training included the biblical foundation of our reasons of doing it, and we brainstormed with them on how to do it. But, more importantly it was on-the-job training. A lot of our targets were illiterate and required more of the "heart" work than "head" work. We led by example, led and modeled them all the way, empowered and supported them at times. Sometimes after big events, they were burnt out. At that time we would have retreats in celebration of what they had done and invited them to our home for a meal. We would give them little gifts to show the value of their participation, so they often received encouragement.

What follows is a detailed description of the implementation of the model.

From House to House

Visitation is one of the key principles of elderly evangelism. It is vital in leading senior citizens to Christ. The key components in this facet are (1) developing and training visitation groups, (2) using four major stages of visitation, (3) employing ten skills during a visit, and (4) applying two key formulas for visitation.

${ }^{2}$ Ellen G. White, The Pastoral Ministry (Silver Spring, MD: Ministerial Association, General Conference of Seventh-day Adventists, 1995), 122. 


\section{Training}

Training church members to visit from house to house is a ministry that cannot be left out in soul winning. ${ }^{3}$

For visitation programs to be successful, however, the pastor must play a leading role. David Gallagher, for example, writes, "As the leadership goes, so goes the church." In other words, "as the pastor goes, so goes the leadership; and as the leadership goes, so goes the people."4 When the pastor himself or herself is 'going' and leading the church, members will also 'go.' Callahan observes that analysis of the most effective visitation programs reveals that "the pastor has taken a major role in actually doing visitation. The pastor has been in the lead." Gary McIntosh has the same view: "The pastor must play the key role in planning, educating, and leading the church toward a blended ministry."6 This means that the pastor is not only providing training and then having the church members do the implementation. Rather he or she trains, leads, gets people involved, and personally does visitation.

In implementing the Four-stage Elderly Evangelism Model, we concentrated on training our members to do evangelistic work during the first three months of the year. At least once a month there was a meeting of all group leaders for training and exchange of experiences. Group leaders were assigned a supervisor/coach who met with them at least

3雷子健, 48,49 .

${ }^{4}$ David P. Gallagher, Senior Adult Ministry in the 21st Century: Step-by-Step Strategies for Reaching People Over 50 (Eugene, OR: Wipf \& Stock, 2006), 15.

${ }^{5}$ Callahan, 13 . 
once a quarter to evaluate their ministry and plan the next steps. The group leaders were regularly informed about available growth and leadership resources. We also trained a worship team that regularly developed and evaluated our worship services. The training included how to sing the gospel opera songs that are so appealing to the mindset of the elderly.

As we visited, we found that the art of visitation is what Callahan terms a "developmental art." It takes time to learn and practice. "One does it best," Callahan writes, "when one does it regularly." "In implementing the Four-stage Elderly Evangelism Model my husband Terry and I were the key persons in leading each team in visitation and in helping them learn visitation skills.

\section{Visitation Groups}

The next step was dividing the church members into various visitation groups. There were ten groups. Each took a turn at visiting on Sabbath afternoons. Their roles were: (1) praying for the elderly whom they visit, (2) phoning them and inviting them to the church, (3) making friends with them, (4) visiting them regularly, e.g., during Chinese festivals and on other occasions, (5) giving them Bible studies, (6) referring them to the pastor to follow up for baptism, (7) taking pictures during each visit, ${ }^{9}$ and (8) after each

${ }^{6}$ Gary McIntosh, Three Generations: Riding the Waves of Change in Your Church (Grand Rapids, MI: Revell, 1995), 177.

${ }^{7}$ Callahan, 16.

${ }^{8}$ Ibid.

${ }^{9}$ The pictures taken were shown to the church as our local church mission spotlight. This encouraged and motivated visitors and the congregation as a whole as they watch. 
visit recording their spiritual status, health situation, needs, Bible lessons they have studied, and their responses to the gospel message.

After the church members had built friendships with them, cared for their needs, and given them Bible studies, I as the pastor would do the last step of encouraging them for baptism.

\section{Four Major Stages of Visitation}

There are four major stages of visitation that make it effective. ${ }^{10}$

1. Seeking. This means intentionally and thoughtfully selecting and seeking those we plan to visit. In our case, we first visited those elderly members of the Center who regularly attended our programs and had shown interest in the gospel.

2. Sharing. This means to build friendships with the elderly in our visits by sharing our background and seeking common ground, hurts, and hopes, etc.

3. Caring. This goes to a deeper level of visitation. It is finding their needs and meeting them.

4. Winning. This refers to giving the elderly Bible studies and encouraging them to follow Jesus Christ.

\section{Ten Skills in a Visit}

There are ten skills we adhered to in our visitation of the elderly: (1) prepare a gift for the elderly for each visit such as fruits, biscuits, and daily necessities, etc. This shows our caring attitude toward them, (2) be courtesy and polite, (3) always smile to make

\footnotetext{
${ }^{10}$ General ideas are adapted from Callahan. See Callahan, 15, 16.
} 
them feel we are warm, (4) patiently listen to the elderly, (5) our conversation is respectful, positive, and with commendations, (6) quote the Bible in answering questions, (7) keep visits short, 15-20 minutes is enough for the elderly, (8) share the miracles of healing and message of hope in Jesus, (9) make the next appointment, and (10) leave a blessing by holding their hands and praying with them.

\section{Two Key Formulas for Organizing Visitation}

There are two practical visitation-mission-growth formulas for visitation: ${ }^{11}$

1. Setting the number of visits per week. In a medium-to-large church use 20 visits per week: 10 for the pastor and 10 for a layperson,

2. Setting the number of visits per year. Multiply the 20 visits per week by 48 weeks to arrive at 960 visits per year.

We followed through with this formula and found the results amazing and encouraging to both pastor and church members.

\section{From Confrontational Evangelism to Friendship Evangelism}

There are three primary ways to deepen friendships with the elderly: (1) be open, (2) be honest, and (3) be compassionate. ${ }^{12}$ When we are open they tend to be open as well. When we are honest, they are inclined to trust us. When we are compassionate, they recognize that we care.

${ }^{11}$ Callahan, 14.

${ }^{12}$ Alan Loy McGinnis, 我怎樣討人喜歡 (The Friendship Factor: How to Get Close to the People You Care for), trans. 王伍惠亞, Chinese ed. (Taipei: Taosheng, 2000), 53-64. 
We manifested our friendship to the elderly through visitation, presenting programs and in worship. When they came to the church, we welcomed them warmly, shaking hands, and showing them respect as if they were our parents. After each Sabbath worship service, we would provide a gift as a token of appreciation for their attendance. The purpose of the gift was to show them that we love and care. We would also ascertain and meet their needs and assist them in learning-type classes.

Below is a description of what we did in caring ministry and learning class.

\section{Caring Ministry}

A major emphasis of friendship evangelism was the caring ministry, based on the passages of Matt 25:31-46 and Isa 58:7-11. This means showing "God's love by meeting needs." 13

The Caring Ministry team intentionally prepared extra food for our Sabbath fellowship meals. During the visitation on Sabbath afternoons we distributed lunches to those who are poor, mostly single elderly. During visitation, when we discovered they were ill, we would take them to see the doctor, and then visited them at their homes or in the hospital. We would also help cut their hair, clean their houses, help with their grocery shopping, etc.

\section{Learning Classes}

Apart from building relationships and friendships with the elderly through caring

\footnotetext{
${ }^{13}$ W. Oscar Thompson, Carilyn Thompson Ritzmann, and Claude V. King, Concentric Circles of Concern: Seven Stages for Making Disciples (Nashville, TN: Broadman \& Holman, 1999), 149.
} 
ministries, we also formed relationships with them through a variety of learning classes. By presenting these classes for them, they felt our caring presence. We have learned not to underestimate the learning spirit of these elderly. They work very hard and attentively.

The following classes are meaningful to the elderly:

1. Literacy Class. As noted, many elderly in Hong Kong are illiterate. Therefore, we offered literacy class at the Center. Various classes, such as Chinese character recognition, Chinese simplified characters, and English language were offered to benefit the elderly who had not had the opportunity of attending school. The result of learning simple vocabulary made them feel more confident and less unappreciated. These types of literacy classes also helped them overcome fear and resistance to studying the Bible.

At some social centers in the area the staff members read the morning news to the elderly, who listen attentively. As a result they feel less detached from the surrounding society. In some cases they are interested in listening to Bible stories and are glad and willing to recognize and recite the Bible verses printed on a handout provided. As part of the curriculum we gradually taught them memory texts from the Bible. Also, we used pictorial aids in presenting the Bible stories. Because the elderly forget easily, we used repetition to emphasize what it means for them to believe and accept Christ.

2. Memory Verse through Sign Language. To help the elderly communicate and socialize with their acquaintances who are hearing impaired, sign language classes were offered. As mentioned, we do not underestimate the learning spirit of these elderly. They work very hard and attentively. That is why Bible verses translated into sign language were introduced to them and impressed on their memories. 
3. Cantonese Singing Class. ${ }^{14}$ The elderly like listening to music, especially the opera songs with traditional Cantonese tunes. They are quite familiar with many of these tunes. We incorporated the gospel messages into the lyrics and taught them how to sing. Some other denominations also transcribe and add the lyrics of Bible texts into these tunes. They are easy to learn and are very meaningful. The elderly love listening to them and learning them, and they provide comfort and good messages. It is easy and effective to preach the gospel through using these Cantonese songs.

4. Reminiscing and Story-Telling. The elderly love to tell stories about their own lives and what they did when they were young. While they are telling these stories about their personal lives, we interjected stories about some similar events, experiences, and occurrences in the lives of biblical characters. This way, through the vehicle of their personal reminiscences and conversations, the truth of the Bible and its stories can be introduced to them.

From Chinese Festivals to Celebration and Feast

Chinese festivals are extremely meaningful to the elderly. The strategy included in the Four-stage Elderly Evangelism Model is to make good use of these festivals as a means of sharing the gospel with them. We celebrated during the programming, and then provided a big feast (fellowship meal) afterwards. Many elderly liked these feasts and attended. Also, Chinese like drinking tea. We offered a Week of Prayer, called a "Gospel Tea Party." We included Gospel opera songs, lucky drawings, gifts, and sermons.

${ }^{14}$ Cantonese is the Chinese language spoken in Hong Kong as opposed to Mandarin spoken in other parts of the Chinese world. 
Usually over 100 elderly would purchase tickets to attend. They needed to buy a ticket in order to attend our programs. That way, they actually pay to listen to the gospel. This is symbolic because what we give them is more than the value of the ticket, but buying a ticket helps them to remember the event.

Every time a holiday approaches, people increasingly miss their friends and loved ones. These holidays means a lot to the Chinese in terms of festivities and family gettogethers. We utilized these holidays as special occasions to invite the elderly to attend and enjoy the programs designed especially for them such as Chinese New Year, ${ }^{15}$ Easter, Mother's Day, Dragon Boat Festival, ${ }^{16}$ Father's Day, Gospel Tea Party, MidAutumn Festival, ${ }^{17}$ Evangelistic Campaign in October, Senior Citizen's Day on the third Sunday of November, and Christmas. These were times when we arranged the best programs for their activities. Many attended these special occasions.

We promoted our programs during the Center's monthly members meeting. Then, before each program we phoned them to remind them, usually a few hours before the

15“The Lunar New Year is the most important date in the Chinese festival calendar. It is celebrated during the days of the first new moon of the year, an auspicious time for friends and relatives to visit each other and to exchange gifts while children and unmarried adults receive lai see, or 'lucky money' in red packets." See "Religion and Custom," Hong Kong 2007 (Hong Kong: Information Services Department of the Hong Kong SAR Government, 2007), http://www.yearbook.gov.hk/2007/en/pdf/E18.pdf (accessed 22 July 2009).

${ }^{16}$ “'The 'Dragon Boat Festival' is celebrated on the fifth day of the fifth lunar month to honor an ancient Chinese poet, Qu Yan, who killed himself by jumping into a river rather than compromise his honor. Dragon boat races and the eating of rice dumplings, wrapped in bamboo leaves, are the highlights of this festival." See Ibid.

${ }^{17}$ "Mid-Autumn Festival, on the 15th day of the eighth lunar month, grownups and children gather under the full moon with colorful lanterns and eat moon cakes, a traditional festival delicacy." See Ibid. 
event. The elderly forget easily, and calling them a few hours prior to the event is more effective than calling them the day before. A gift was given to each at the end of each program to show our appreciation and care. What follows are descriptions of some Chinese festivals and our adaptations.

\section{Chinese New Year}

During Chinese New Year, people like anything that symbolizes luck, such as red money envelopes into which we inserted small cards printed with Bible verses of blessings and hand carried to the elderly family along with a gift of tangerines. A sixperson team, which included two young adults, two teenagers, and two pre-teens, visited each family. The team leader asked his teammates to join him in pronouncing a few auspicious phrases of blessing for the New Year and then the group sang a song or two to share the joy. After that, one of the young people offered a prayer followed by a teenager presenting the red envelope and present to the elderly in the home. Most of them were happy and enjoying themselves. It was not difficult to invite them to church afterwards.

\section{Mid-Autumn Festival and Dragon Boat Festival}

These are two traditional Chinese holidays. The Mid-Autumn Festival denotes the celebration of reunion or family get-togethers. The special feature of this festival is the moon cake.

At the Dragon Boat Festival people enjoy eating zong $z i$, glutinous rice balls with a filling and wrapped in bamboo leaves. Often our church coordinates with the staff members at the Social Center by sending them zong $z i$ prepared by the center volunteers or moon cakes donated by other charitable organizations to the families of the elderly. 
This festival commemorates the heroic sacrifice of Qu Yan, who drowned himself in the Milou River rather than compromise his honor. It also emphasized friendship gettogethers. During these festivals we described to people the great sacrifice that the Lord Jesus made for the whole of humankind and the big reunion in heaven for those who accept Him as their personal Savior and further understand the true meaning of the Christmas celebration.

\section{Senior Citizen's Day and Christmas}

The Senior Citizen's Day is a perfect time for us to show respect to the elders. Christmas is a joyous occasion for the whole world to celebrate the birth of Jesus and His coming to save the human race. That is why we made extensive efforts of inviting the elderly to come not only as spectators but also as participants in the programs specially prepared for them on these special days.

\section{Mother's Day and Father's Day}

These are much-anticipated annual programs for the elderly. We took them to a restaurant for dinner, including the presentation of programs and dramas. Sometimes we had a tea time party at a restaurant. They purchased tickets and came to join the party. They felt they were respected, and were joyful in spending these happy moments with so many church members who reminded them their own sons, daughters, and grandchildren. The elderly enjoyed eating with lots of people like one big family.

\section{Gospel Tea Party}

A rough estimate is that about one third of the regular elderly members of the Center who regularly attended monthly meetings would buy tickets and join our Gospel 
Tea Party. Typical attendance ran around ninety. People in Hong Kong are in the habit of taking tea around 4:00 to 5:00 p.m. every day, or on Sunday in the morning. The whole family will get up at around nine o'clock and get ready for tea or brunch. Around four o'clock in the afternoon we usually hosted a tea party so the elderly could attend and sing along with gospel karaoke, listen to Bible messages, eat pastries, have tea, and receive gifts. A lot of elderly attended these afternoon functions, and they make the elderly very happy.

We have used the Gospel Tea Party idea as part of the Four-stage Elderly Evangelism Model in my church for over four years. The content of the program includes Chinese Opera gospel songs, Bible study, a lucky drawing, gifts, and food. We present it twice a week-almost 100 times a year. It is a very successful and wonderful program. The average attendance is about ninety elderly. They really enjoy it and are happy with this program. They have to buy a ticket each month to join this program, which gives it even more meaning to them.

To make these kinds of activities work, we had to find people who were willing to dedicate time to be involved, were willing to be trained, and were willing to lead out in the various segments of the programs. For the Gospel Tea Party ministry we needed about a 20-member team. The more these team members participated, the more confidence they developed in the program, and the more they learned about how to lead people to Christ. This was a win-win program that is more than worth doing. These Gospel Tea Parties represent celebration event and also feast times. Every month, we also hold a big feast after the Sabbath worship for the elderly. It is a time for fellowship and joy. We serve over twenty courses at this meal. 


\section{From Worshipping Forefathers to Worshipping the Heavenly Father}

We intentionally made our worship services culturally-relevant. We used the opera songs that are familiar to the elderly, and we trained our song leaders on how to use and sing these songs. Our sermons were mostly presented using PowerPoint so that the elderly could read from the screen.

\section{Gospel Opera Songs}

The elderly love music, especially the traditional Chinese opera songs. We changed the lyrics to gospel contents. As a result, they really enjoyed them and the message got into their minds easier and in a more natural way. For our song services, we had a pianist and two guitarists playing the music and three or four people on the platform leading the service. We sang a lot of songs, usually for around twenty minutes worth. This generated an atmosphere of worship.

\section{Preaching}

The sermons were specially designed for the elderly. We tried to use simple words for them. Themes that we repeatedly mentioned are God's blessings, eternal life, peace of mind, salvation, God's love, etc. We lead them step by step toward salvation and made appeals during every sermon.

As noted, filial piety is important to the Chinese mind. Choi's work gave us some insights on how to preach to the elderly. "The hsiao-in-Christ model of caring for the elderly," he writes, "brings the idea that pastors and teachers should show respect and love the elderly as they deliver sermons and teach lessons. Storytelling is an appropriate method of preaching for the elderly. Stories can be told including stories of older people 
in the Bible, stories of people in Chinese ancient literature as well as modern society, stories of persons in the congregation. Pastoral preaching relates human stories with God's great stories. This kind of reaching may inspire elders to grasp the meaning of life and the hope and power to live."18

As noted, many Chinese are ancestor worshipers and tend to be superstitious. Accepting a foreign religion is not easy for them. We started from the simplest point of contact. In Chinese culture God is described as "heaven." We emphasized that this "heaven" is the Creator God in the Bible. The OT Israelites sacrificial offering system harmonizes with Chinese cultural practices and is a natural point of contact. Instead of burning incense, we pray with them. We also emphasis that honor to parents is the first Commandment with a blessing. These points harmonize with the teachings of Confucius.

The Chinese have been deeply influenced by Confucianism ${ }^{19}$ and Taoism. ${ }^{20}$ Many people consider it very important to continue the traditional belief of worshiping their ancestors even to the point of superstition. This tradition is handed down from one generation to another and is deeply rooted in the lesson of piety.

${ }^{18}$ Choi, 183.

${ }^{19}$ “'Confucianism is the belief in the teachings of Confucius. ... His teachings were based on a moral code for human relations with emphasis on the importance of tradition and rites. He was one of the most eminent thinkers of the time, a great sage and educator whose philosophy has deeply influenced the political, economic and social systems of China." See "Religion and Custom," 361.

${ }^{20}$ c Taoism is an indigenous religion of China with a long history of over 2000 years. Honoring Taishang Laojun (Li Dan) as the Supreme Patriarch, Taoism advocates simple living and harmony with nature... . Taoist gods are classified under two headings: Prior Heavens and Posterior Heavens. Mortal gods of Posterior Heavens . . . are revered for their great virtues and feats in saving mankind." Ibid., 361, 362. 
It is not easy to change it overnight. In a positive light, its benefits lay in the concept of treating one's parents with piety and respect. Generation after generation is taught to respect the deceased ancestors and to worship them by burning incense in front of their altars on a daily basis. The only thing that is commendable about this is the reverence and piety aspect, so to lead them to the Christian faith we have to go slowly, starting with the basics. We show how in the Bible the ancient Israelites, through burning incense and through cow and sheep offerings, carried out almost exactly the same ritual as the Chinese do today when offering roasted pigs to their ancestors, except that the Israelites submitted all these offerings to only one God.

\section{Summary}

While the implementation of this project took more than two years, longer than expected, the lengthened span allowed for a better evaluation of how well the model worked.

The four foundational principles worked harmoniously and related well to one another. Building good friendships and relationships with the elderly was demonstrated to be the key element. It worked well in the visitation, culturally-relevant competent programs, and in the dynamic worship segment. Visitation was tested and shown to be effective in elderly evangelism. I was overjoyed to discover that the number of visits made by myself as pastor and those of the laity were almost equal.

As we intentionally made the programs more culturally relevant and seeker sensitive, we found that attendance increased, an encouraging outcome. Some people originally thought that dynamic worship was only important to young people. Nevertheless, we found that the elderly were delighted and enjoyed the Gospel Opera 
Songs with Christian lyrics, and that they understood and could participate in the singing. We also discovered that the sermons were appealing to their deeper inner needs. This helped them encounter God, and their trust in God grew as they worshiped. It proved accurate that, as one writer expressed it, "worship is also union with Christ and lifts the believer to the highest moral and spiritual level. It is intended to be a lasting union in which the mind of Jesus becomes the mind of believer, which is thus completely united with the will of God."21

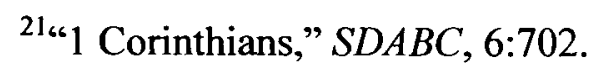




\section{CHAPTER 6}

\section{EVALUATION OF THE PROJECT}

The purpose of this chapter is to evaluate the effectiveness of the implementation of the Four-stage Elderly Evangelism Model in the areas of visitation, friendship evangelism, competent programs, and dynamic worship.

\section{Evaluation of the Four-stage Elderly Evangelism Model}

The tools used to assess the four key aspects pertaining to elderly evangelism are: (1) Church Member Survey, ${ }^{1}$ and (2) Data/statistics. The data provided in the Church Member Survey indicated the twelve members' evaluation of the process rather than the perspectives of the elderly population that we were trying to reach.

The Church Member Survey was designed to ascertain how the church members viewed the changes as a result of the implementation of the Four-stage Elderly Evangelism Model. The survey was administered to twelve members of Siu Sai Wan Church handpicked by myself and who were actively involved through participating in the Elderly Evangelism Model at both its beginning and conclusion (i.e., January 2007 and December 2008). The survey was designed as both a pre- and post-test.

The results indicated that the members' involvement increased. Separate results

${ }^{1}$ A copy of the survey questionnaires is found in the appendix. Some ideas came from Callahan's Twelve Keys to an Effective Church. See Callahan, 23, 34, 71. 
for the four major segments: (1) Pastoral and Lay Visitation, (2) Friendship Evangelism, (3) Competent Programs, and (4) Dynamic Worship are listed under the following sectional headings.

\section{Pastoral and Lay Visitation}

Research showed that the raw scores indicate increased involvement by the members (see table 4). There was an increase in the number of selected members who were in regular visitation or phone contact with the elderly seekers and the elderly church members.

Table 4. Members' Involvement on Visitation and Phone Contact

\begin{tabular}{|c|c|c|c|c|c|}
\hline Questions (N=12) & Never & Seldom & Sometimes & Usually & Always \\
\hline \multicolumn{6}{|c|}{$\begin{array}{l}\text { 1. In regular visitation or } \\
\text { phone contact of the seekers } \\
\text { of the elderly center }\end{array}$} \\
\hline a. Pre-test Scores: & 3 & 3 & 5 & 1 & 0 \\
\hline b. Post-test Scores: & 1 & 3 & 4 & 1 & 3 \\
\hline \multicolumn{6}{|c|}{$\begin{array}{l}\text { 2. In regular visitation or } \\
\text { phone contact of the elderly } \\
\text { church members }\end{array}$} \\
\hline a. Pre-test Scores: & 3 & 3 & 5 & 1 & 0 \\
\hline b. Post-test Scores: & 1 & 2 & 5 & 0 & 4 \\
\hline
\end{tabular}

Note: The pre- and post-test raw data shows how the selected church members were involved in the Four-stage Elderly Evangelism Model before and after the implementation period (January 2007 to December 2008). 
Also, the data/statistics showed the average annual visitation or phone contact by lay members to be quite high, $701,{ }^{2}$ there was a gain $95.81 \%$ in visitation and phone contact by the lay members, ${ }^{3}$ and a gain of $109.15 \%$ by the pastor. ${ }^{4}$ This finding pointed out that the church actually improved in this aspect of elderly evangelism. ${ }^{5}$

\section{Friendship Evangelism}

Research showed that the raw scores for Friendship Evangelism indicate that the

${ }^{2}$ This was the average number between 2006 to 2008 . This number was used because the implementation began slowly in 2006 and ended in 2008 . The figures for the visitation or phone contact by lay members for 2006 to 2008 are 420,538 , and 1145 respectively.

${ }^{3}$ The number of visitations and phone contacts by the church members for 2003 and 2004 were not recorded, so we took the number of 2005 (i.e., 358) as the average between 2003 and 2005 . When compared to the annual average of 701, between 2006 to 2008 , the gain was $95.81 \%$.

${ }^{4}$ The number of visitations or phone contacts by the pastor between 2005 and 2008 were 328, 477, 462, and 1119 respectively. Again the figures for 2003 and 2004 were not recorded, so we took the number of 2005 (i.e., 328) as the average between 2003 and 2005. The average between 2006 to 2008 and 2003 to 2005 was 686 and 328 respectively, a gain of $109.15 \%$. The numbers for the pastor (one person) and the church members (over 12 people) were very close; again it demonstrated the influence of the leadership in visitation. See Callahan, 13, 14.

${ }^{5}$ The number of visits dropped in 2008 due to the fact that church members' efforts were shifting from visitation to worship. Due to the success and acceptance in 2007 of the Gospel Tea Parties, the church changed its strategy at the beginning of 2008 and began holding these Gospel Tea Parties on Wednesdays and Saturdays throughout the entire year. As a result of this shift, and the fact that many elderly from the Center were attracted to the Sabbath worship services and to the Gospel Tea Parties, the worship service was adjusted to be more evangelistic. As a result of that shift, the energies of the church members were suddenly absorbed by the worship service, and they met most of the elderly whom they formerly visited at the church itself. As a result the number of visits reported dropped significantly. On the other hand, the number of phone contacts increased as the elderly needed to be reminded from time to time to attend our Gospel Tea Parties on Sabbaths. The figures for the visitation for 2006 to 2008 were 317, 175, and 118 respectively. Phone contacts were 103,363, and 1,027 respectively. 
members' involvement increased (see table 5). It indicated that the selected church members felt they "usually" and "always" prayed for the seekers, had a passion for soul winning, cared about other members, and as a result, guests would feel welcomed and cared for by the church.

Table 5. Members' Involvement in Friendship Evangelism

\begin{tabular}{|c|c|c|c|c|c|}
\hline Questions ( $N=12$ ) & Never & Seldom & Sometimes & Usually & Always \\
\hline \multicolumn{6}{|c|}{$\begin{array}{l}\text { 1. Our church members } \\
\text { exhibit quality care of other } \\
\text { members regularly }\end{array}$} \\
\hline a. Pre-test Scores: & 0 & 1 & 4 & 4 & 3 \\
\hline b. Post-test Scores: & 0 & 1 & 1 & 4 & 6 \\
\hline \multicolumn{6}{|c|}{$\begin{array}{l}\text { 2. Guests/seekers feel } \\
\text { welcomed and cared for by } \\
\text { our church }\end{array}$} \\
\hline a. Pre-test Scores: & 0 & 1 & 4 & 5 & 2 \\
\hline b. Post-test Scores: & 0 & 1 & 0 & 3 & 8 \\
\hline \multicolumn{6}{|c|}{$\begin{array}{l}\text { 3. Church members regularly } \\
\text { pray for the salvation of } \\
\text { specific individuals }\end{array}$} \\
\hline a. Pre-test Scores: & 0 & 2 & 5 & 4 & 1 \\
\hline b. Post-test Scores: & 0 & 0 & 2 & 9 & 1 \\
\hline \multicolumn{6}{|c|}{$\begin{array}{l}\text { 4. I routinely exhibit a passion } \\
\text { for soul winning }\end{array}$} \\
\hline a. Pre-test Scores: & 0 & 2 & 4 & 5 & 1 \\
\hline b. Post-test Scores: & 0 & 0 & 3 & 4 & 5 \\
\hline
\end{tabular}

Note: The pre- and post-test raw data shows how the selected church members were involved in the Four-stage Elderly Evangelism Model before and after the implementation period (January 2007 to December 2008). 


\section{Competent Programs}

Research showed that the raw scores for Competent Programs indicate that the church's competency in programming increased (see table 6). The raw scores showed that more selected members checked "Always" as compared to the other three aspects.

While the surveys provided some subjective views on how the selected members perceived the effectiveness of the Four-stage Elderly Evangelism Model, it would be beneficial to look at some objective data/statistics on how the church was doing in the aspect of competent programs. The data/statistics were as encouraging as the survey. There were gains in: (1) number of evangelistic meetings, $304.47 \% ;{ }^{6}$ (2) number of elderly non-Adventist seekers who attended evangelistic meetings, $587.80 \%{ }^{7}$ and (3) the total attendance in all evangelistic meetings, $447.20 \%{ }^{8}$ See table 7.

${ }^{6}$ The number of evangelistic meetings from 2003 to 2008 are $22,12,11,24,56$, and 102 respectively. The average between 2003 to 2005 and 2006 to 2008 are 15.00 and 60.67 respectively, a gain of $304.47 \%$.

${ }^{7}$ The average number of elderly non-Adventist guests attending evangelistic meetings from 2003 to 2008 are $248,117,94,478,1,302$, and 1,377 respectively. The average between 2003 to 2005 and 2006 to 2008 are 153.00 and 1,052.33 respectively, it makes a gain of $587.80 \%$. Note: This is an average of people attending, individuals may be included in more than one meeting.

${ }^{8}$ The total attendance of all evangelistic meetings from 2003 to 2008 are 1,034 , $544,418,1,268,3,597$, and 6,057 respectively. The average between 2003 to 2005 was 665.33 , and between 2006 to 2008 was 3,640.67; it makes a gain of $447.20 \%$. 
Table 6. Church's Competent Programs

\begin{tabular}{|c|c|c|c|c|c|}
\hline Questions (N=12) & Never & Seldom & Sometimes & Usually & Always \\
\hline \multicolumn{6}{|c|}{$\begin{array}{l}\text { 1. Our church } \\
\text { programs/events are directed } \\
\text { towards accomplishing our } \\
\text { missional objectives }\end{array}$} \\
\hline a. Pre-test Scores: & 0 & 0 & 5 & 4 & 3 \\
\hline b. Post-test Scores: & 0 & 0 & 1 & 3 & 8 \\
\hline \multicolumn{6}{|c|}{$\begin{array}{l}\text { 2. Our programs/events in the } \\
\text { church are connected to the } \\
\text { participants }\end{array}$} \\
\hline a. Pre-test Scores: & 0 & 3 & 1 & 6 & 2 \\
\hline b. Post-test Scores: & 0 & 0 & 1 & 5 & 6 \\
\hline \multicolumn{6}{|c|}{$\begin{array}{l}\text { 3. Our church conducts } 1 \text { to } 3 \\
\text { outreach events per year that } \\
\text { are respected by the elderly } \\
\text { members of the center }\end{array}$} \\
\hline a. Pre-test Scores: & 0 & 1 & 6 & 3 & 2 \\
\hline b. Post-test Scores: & 0 & 0 & 1 & 2 & 9 \\
\hline \multicolumn{6}{|c|}{$\begin{array}{l}\text { 4. Our outreach events are } \\
\text { high quality }\end{array}$} \\
\hline a. Pre-test Scores: & 0 & 3 & 4 & 5 & 0 \\
\hline b. Post-test Scores: & 0 & 1 & 0 & 4 & 7 \\
\hline \multicolumn{6}{|c|}{$\begin{array}{l}\text { 5. Our outreach events are } \\
\text { sensitive to different the } \\
\text { cultural, spiritual, and } \\
\text { educational diversities }\end{array}$} \\
\hline a. Pre-test Scores: & 0 & 4 & 3 & 3 & 2 \\
\hline b. Post-test Scores: & 0 & 1 & 1 & 3 & 7 \\
\hline
\end{tabular}

Note: The pre- and post-test raw data shows how the selected church members viewed the church's involvement in the Four-stage Elderly Evangelism Model before and after the implementation period (January 2007 to December 2008). 
Table 7. Number of Evangelistic Meetings, Elderly Non-Adventist Guests Attendance, and Total Attendance

\begin{tabular}{lccc}
\hline Year & $\begin{array}{c}\text { Number of } \\
\text { Evangelistic Meetings }\end{array}$ & $\begin{array}{c}\text { Elderly Non- } \\
\text { Adventists Attendance }\end{array}$ & $\begin{array}{c}\text { Total } \\
\text { Attendance }\end{array}$ \\
\hline 2003 & 22 & 248 & 1,034 \\
2004 & 12 & 117 & 544 \\
2005 & 11 & 94 & 418 \\
2006 & 24 & 478 & 1,268 \\
2007 & 56 & 1,302 & 3,597 \\
2008 & 102 & 1,377 & 6,057 \\
\hline
\end{tabular}

Note: All data is from 2003 to 2008 . Total attendance includes the attendance of the elderly non-Adventists, other non-Adventists, and all church members.

\section{Dynamic Worship}

Research showed that the raw scores for Dynamic Worship indicate an increase in member satisfaction (see table 8). The selected church members agreed that our worship service was of high quality each Sabbath.

The data (see table 9) showed there was a gain of $47.49 \%$ in worship attendance. ${ }^{9}$ This agreed with the survey results that the overall view of the selected church members was satisfactory in this aspect of elderly evangelism.

${ }^{9}$ The average of worship attendance from 2003 to 2008 are 47, 54, 57, 67, 71, and 95 respectively. The average between 2003 to 2005 and 2006 to 2008 are 52.66 and 77.66 respectively, a gain of $47.49 \%$. 
Table 8. Church's Worship

\begin{tabular}{|c|c|c|c|c|c|}
\hline Questions & Never & Seldom & Sometimes & Usually & Always \\
\hline \multicolumn{6}{|c|}{$\begin{array}{l}\text { 1. Our church plans a high } \\
\text { quality worship service each } \\
\text { Sabbath }\end{array}$} \\
\hline a. Pre-test Scores: & 0 & 1 & 4 & 4 & 3 \\
\hline b. Post-test Scores: & 0 & 0 & 3 & 4 & 5 \\
\hline \multicolumn{6}{|c|}{$\begin{array}{l}\text { 2. The music in our church } \\
\text { service is dynamic and } \\
\text { inspirational }\end{array}$} \\
\hline a. Pre-test Scores: & 0 & 0 & 8 & 4 & 0 \\
\hline b. Post-test Scores: & 0 & 1 & 1 & 5 & 5 \\
\hline \multicolumn{6}{|c|}{$\begin{array}{l}\text { 3. The Sabbath sermons from } \\
\text { the pastor are interesting and } \\
\text { inspiring }\end{array}$} \\
\hline a. Pre-test Scores: & 0 & 2 & 5 & 2 & 3 \\
\hline b. Post-test Scores: & 0 & 0 & 1 & 5 & 6 \\
\hline
\end{tabular}

Note: The pre- and post-test raw data shows how the selected church members viewed the worship service in relation to the Four-stage Elderly Evangelism Model before and after the implementation period (January 2007 to December 2008).

Table 9. Worship Attendance

\begin{tabular}{lc}
\hline Year & Worship Attendance \\
\hline & \\
2003 & 47 \\
2004 & 54 \\
2006 & 57 \\
2007 & 67 \\
2008 & 71 \\
& 95 \\
\hline
\end{tabular}

Note: All data shows the average weekly worship attendance from 2003 to 2008 . 


\section{Recommendations}

In my observation, I would make some recommendations for further enhancement of the model. They are:

1. There should be a balance in the implementation of the four principles. I noticed that when we put our energy into dynamic worship, visitation evangelism was neglected. This needs to be balanced so that all our principles are equally implemented and enforced.

2. I noticed that while we were busy with all the programs, prayer was neglected and not equally emphasized. More personal prayers and group prayers are needed to be introduced throughout the implementation process.

3. Our training for the young people was more on the practical part of implementation. We worked together, doing on-the-job training, and that was good; however, training on the theory of the model is equally important. This training should be based on the principles in chapters two to four. When young people have a solid theological foundation and understand the biblical principles, that will shape their thinking on elderly evangelism, and they will serve with greater enthusiasm.

4. Last, we did surveys with the selected members implementing this model. Other surveys with the elderly would enhance our model. We should ask them what they think of the model. We should also seek their recommendations for improvement.

\section{Summary}

Callahan writes, “Those churches that have increased their worship attendance tend also to discover that their membership grows and their financial resources increase 
as well. ${ }^{10} \mathrm{We}$ also found a surprisingly direct correlation between worship attendance, membership growth, and church income.

Church income increased $64.65 \%{ }^{11}$ The elderly baptismal figures listed in table 10 show a significant gain of $79.31 \% .^{12}$

Overall, the outcomes of the evaluation indicate that the Elderly Evangelism Model based on the four biblical principles articulated worked very well. It showed that when church members become involved in personal evangelism and visitation, demonstrate their friendship through caring, focus on programs with the goal of making them competent and missional, and the elderly experience God in these quality worship services, baptisms increase.

God blessed our efforts. All four aspects of the Elderly Evangelism Model proved to be valid and workable. I believe there is a direct correlation between the implementation of the model and the baptismal results. As more church members contacted the elderly through visitation or by phone to show care and understanding of their needs, more were attracted to our competent programs and experienced God in our

${ }^{10}$ Callahan, 32.

${ }^{11}$ These figures represent a comparison of the average for the implementation period, 2006-2008 (HK\$65,265.68) and the average of the preceding three years 20032005 (HK\$107,458.58). The donations from 2003 to 2008 were HK\$71,185.60; $67,680.74 ; 56,930.69 ; 76,357.21 ; 110,987.64$, and $135,030.88$ respectively.

${ }^{12}$ This was calculated between the average number of baptisms between the implementation period (2006 to 2008) and compared it the average of three years before, i.e., from 2003 to 2005 . 
dynamic and culturally relevant worships. As a result, when we approached them through friendship evangelism in a respectful and loving way, their hearts opened to Christ, and an increase of baptisms was the result.

Table 10. Number of Elderly Baptisms

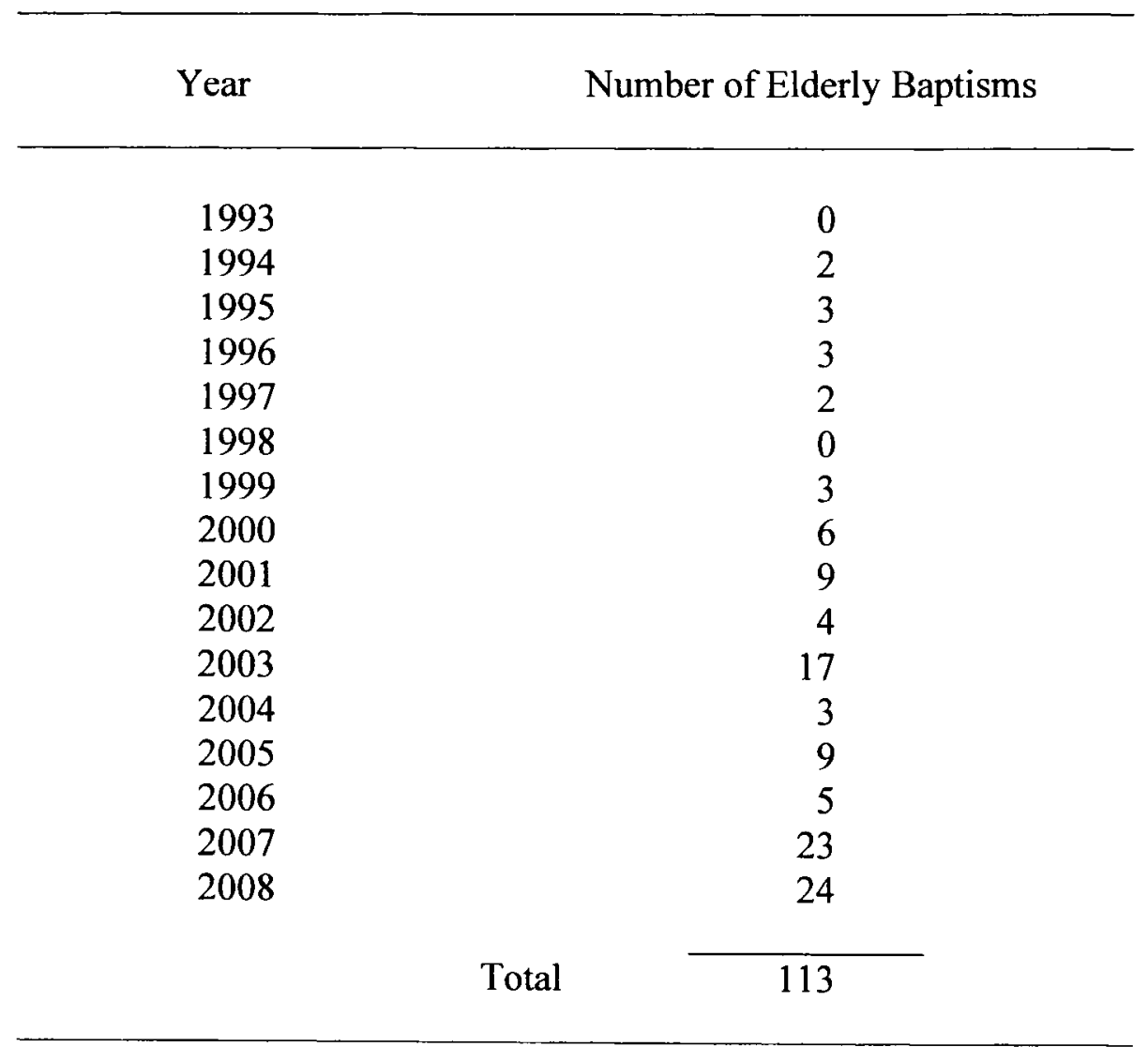

Note: All data is from 1993 to 2008 . The year 1993 began in October. 


\title{
CHAPTER 7
}

\section{SUMMARY AND CONCLUSIONS}

This chapter summarizes the Four-stage Elderly Evangelism Model project in Siu Sai Wan Social Center for the Elderly and presents conclusions and observations.

\begin{abstract}
Summary
The elderly population of Hong Kong is notably increasing. Many people agree that Hong Kong is becoming a so-called "graying metropolis." It is estimated that by the year $2036,26 \%$ of the Hong Kong population will fit into the elderly category. The same scenario is true for the Seventh-day Adventist Church. As a result, the church faces the challenge of reaching out to this often neglected group. Little has been done in the area of elderly evangelism, and it thus represents a fruitful and important area of research.

The Bible itself does not mention specific methodologies for reaching elderly people with the gospel. The Great Commission, nevertheless, includes the elderly group, and the Three Angels' Message is to be preached to every nation, tribe, language, and people. The "people" category would include the elderly. The Great Commandment of loving God and our neighbor as ourselves is the driving force in fulfilling this Great Commission. We need both the commitment of the Great Commission and the compassion of the Great Commandment. These are the two key underlying essentials of elderly evangelism.
\end{abstract}


The Bible does mention treatment of the elderly. They merit respect, deference from the young, exhortation, and most importantly, love. "Blessing" is a very important and meaningful word for the Chinese elderly mind, and the blessings for the elderly mentioned in the Bible present a very encouraging and important message to them. Three elderly conversions, Nebuchadnezzar, Nicodemus, and the 38-year cripple were studied for some insights on forming elderly evangelism principles.

Tradition is very important in Chinese culture, and the traditional Chinese worldview has a great impact on the elderly. In this regard, the issues of filial piety and ancestor worship were considered. This led to the development of principles for use in elderly evangelism. The fifth commandment, to honor our parents, is appealing to the Chinese mindset, especially since it is the first commandment containing a promise: "Honor your father and mother-which is the first commandment with a promise- that it may go well with you and that you may enjoy long life on the earth" (Eph 6:2,3).

Widespread ancestor worship by the elderly is tied to the value of filial piety, though Smith's research demonstrates that in Hong Kong ancestor worshipper is really based more on moral and ethnic backgrounds than on religious motivations or convictions. These considerations help form bridges to elderly conversion, though it is still a difficult task to convert the elderly.

The high degree of illiteracy among the elderly is another issue that must be taken into consideration. Any evangelistic methodology developed must include ways and means of presentation to the illiterate and literacy training.

Taking into account these factors, the Four-stage Elderly Evangelism Model was developed. It is based on four biblical principles: visitation evangelism, friendship 
evangelism, culturally-relevant competent programs, and dynamic worship.

The visitation and friendship evangelism principles are based on the Great Commission perspective of "going," and on Jesus" demonstration of "going" and "visiting" the 38-year elderly cripple. The principle of friendship evangelism is based on the elderly characteristics of needing respect, care, and love. Barna's research shows that friendship evangelism is the most effective method for reaching senior citizens within the American context, and Jesus' attitude in dealing with the 38-year cripple shows His caring and friendly approach may be applied in any cultural context. Friendship evangelism and visitation work together to form the "going" part of the Four-stage Elderly Evangelism Model.

The "coming" part of the model is based on the culturally-relevant competent programs and dynamic worship principles. In the biblical example, Nicodemus was drawn to Jesus by His words and deeds and as a result he "came" to Jesus. In the Fourstage Elderly Evangelism Model, we shared Bible messages and discovered and met the needs of the elderly through visitation. Through friendship evangelism, we demonstrated we were respectful, caring, and loving. As a result of these two phases, when we invited the elderly to second stage events, they attended and participated.

The most successful culturally-relevant competent programs were the gospel tea party and dynamic worship segments. We intentionally changed the lyrics of songs that the elderly were familiar with, that is, the gospel opera songs preached and followed Jesus' methodology of emphasizing the message of new life, heaven, and salvation as in the case of Nicodemus.

We also focused on blessings for the elderly. Meaningful gifts were given to the 
elderly attendees at each worship service as tokens of appreciation for their attention, and as symbols of love and care. One of the most appreciated gifts was called "Rice of Peace." Once a year, there are some volunteer organizations who give out some rice free to the elderly. They call it "Rice of Peace." The elderly like the rice and also its title, as they long for peace. They will queue for hours in order to get a bag of rice. We borrowed this concept and used it as a gift for the elderly. They all liked it and appreciated it so much. We intentionally put the rice in a red bag as they all like red. A Chinese character of "blessing" was printed on the bag. Also, during Chinese New Year, most people put messages of luck and post them on their doors and walls. We used this concept in our sermons, preaching those messages of luck, and also put these messages in a "red pocket." The elderly gladly received them.

As Daniel's testimony and worship to God had great influence on King Nebuchadnezzar's conversion, we found that our testimony through the practical religion of caring and dynamic worship deeply impressed the minds of the elderly and moved them toward conversion.

The implementation of the Four-stage Elderly Evangelism Model took place over a two-year period beginning slowly in 2006. Evaluation took place at the end of the implementation to measure its effectiveness. A core group of twelve members rated each of the four stages of the model before and after implementation. The pre- and postevaluation instruments showed that the mean score for the pre-test was 3.29 and the posttest score was 4.18 , a gain of 0.89 or $26.94 \%$. The survey results were satisfactory and showed improvement by using the model. The average respective gains for the four stage of visitation evangelism, friendship evangelism, cultural competent programs, and 
dynamic worship were $39.29 \%, 18.88 \%, 29.79 \%$, and $28.78 \%$.

The surveys provided the subjective views of the members on the changes accomplished by the implementation of the four aspects of the model. The data/statistics evaluation provided more objective numbers for what was actually happening.

For visitation evangelism, there was a gain of $95.81 \%$ in the number of visits and phone calls made by the church members. ${ }^{1}$ The visits made by the pastor increased by $109.15 \%$.

For the competent programs, the data/statistics were indeed very encouraging. There were gains in (1) number of evangelistic meetings, 304.47\%; (2) number of elderly non-Adventist seekers who came to evangelistic meetings, $587.15 \%$, and (3) the total attendance at all evangelistic meetings, $447.20 \%$. This proved that once we made the programs more culturally-relevant and competent, crowds were attracted to the events. For dynamic worship, there was a gain of $47.49 \%$ in worship attendance.

There was also a significant increase in baptisms. Table 10 showed that there was a total of 113 elderly baptisms from the opening of the elderly center in October 1993 through December 2008. As we developed skill and fully implemented the Four-stage Elderly Evangelism Model by 2007 and 2008, we discovered that the elderly baptisms were the highest in those years; 23 and 24 individuals respectively, which constitutes $41.6 \%$ of the total baptisms over a 16 year period.

\footnotetext{
${ }^{1}$ The comparison in all four aspects was made by the average of the implementation period, 2006-2008, compared to the average of the prior three years, before 2003-2005.
} 


\section{Conclusions}

Over the past fifteen years, my husband and I have tried many different methods of evangelism at Siu Sai Wan Social Center for the Elderly. Overall, this Four-stage Elderly Evangelism Model is the best evangelistic initiative of all. The survey results and the data/statistics demonstrate that this model was implemented effectively and the results were fruitful. We believe God works through His biblical principles and through those who are committed to those principles.

When the implementation of this project was at its maximum during most of the Sabbaths in 2008, there were more than twenty church members standing outside who could not get into the church because it was packed full. In 2009 we organized two worship services, one focused on elderly evangelism, the other more nurturing for the younger church members. Indeed, the whole church was joyful as we saw so many elderly baptized.

\section{Observations}

We did well by the grace of God in many aspects; however, there are areas that still need improvement. The first is a spirituality component. This aspect is not covered in the Four-stage Elderly Evangelism Model, but I think it is very important to evangelism. It is the internal fuel that drives us forward. Ellen White counsels, "While we are to labor earnestly for the salvation of the lost, we must also take time for mediation, for prayer, and for the study of the word of God."2 Second, while this project emphasizes friendship evangelism, there is need for training the church members in how to personally reap the

\footnotetext{
${ }^{2}$ White, The Desire of Ages, 362.
} 
harvest and get decisions. Third, there is a need for regular group evaluation. This will help us work more effectively.

My husband and I, as pastors, did pay a price throughout those years of implementation, especially on training the members. From time to time, we told them the importance of soul winning as the elderly were aged, with an urgency in reaching them because of the time factor. If we did not save them, then no one would save them. Again and again, we emphasized that we needed to reach them with love and caring, earnest respect. I noticed that the young people were greatly encouraged when I led out in doing evangelism. First, they observed how I did it, then they gained confidence as they practiced it. I would accompany them, observe, and help. I also encouraged and showed appreciation for their work. As a result, they were highly motivated and gained greater confidence. I noticed faith begets faith, earnestness begets earnestness.

We were fully committed and believed in these principles, and we were so amazed and gratified to see the results. Over the past fifteen years of working in Siu Sai Wan Church as the pastor, there have been a few occasions when I thought I might be transferred to other churches. The motivation to change was strong. I live a long way from Siu Sai Wan Church, commuting three hours a day on the road. I have stayed many years in one church and there may be even greater needs in other places. Nevertheless, God had His reasons for keeping me there until I finished implementing and leading out in a model for elderly evangelism. When I knew that I would be leaving the church on April 1, 2009 and joining my husband in Global Chinese Evangelism in the Chinese Union Mission, I was truly weeping in my heart daily as I traveled to Siu Sai Wan. This project helped me love the elderly more and more and respect them as my 
own parents. This, in turn, developed my character, and I understand more of what Ellen White means, "God could have reached His object in saving sinners without our aid; but in order for us to develop a character like Christ's, we must share in His work."3

Every Sabbath when I saw the elderly coming to the church, it seemed that I saw the holy angels leading and guiding their staggering steps into the house of the Lord. We experienced great joy as we saw them baptized. Some have passed away since the implementation of this project. We will have greater joy when we unite together in heaven one day, when Jesus comes back again.

Once, an elderly gentleman called himself a "third-class citizen." In Chinese, 'class' and 'wait' are the same word. "What he meant was that the elderly are waiting for three things: to eat, to sleep, and to die. That may well be the picture of those who do not know Christ and the hope of salvation and heaven." come to know Jesus Christ and accept His salvation, they will be waiting for something better by contrast-the second coming of Jesus, eating the fruit of the tree of life (Rev 22:2), worshiping God day and night for they do not need to sleep ( $\operatorname{Rev} 22: 3-5 ; 7: 15$, NRSV), and inheriting eternal life and an incorruptible body (1 Cor 15:52, 53). Then they will become the heavenly "first-class citizens."

I pray and believe that I will see many elderly in heaven, but they will no longer be old and weak. As the prophet Isaiah says, "He who dies at a hundred will be thought a mere youth" (Isa 65:20). This is the joy of working with the elderly. Amen!

\footnotetext{
${ }^{3}$ White, The Desire of Ages, 142.

${ }^{4}$ Terry and Linda Tsui, "Elderly Evangelism: A Challenging and Rewarding Ministry," Adventist World, May 2007, 14.
} 


\section{APPENDIX}

\section{CHURCH MEMBERS SURVEY}

Using the scale 1-5 below, please rate your/the church's evangelistic involvement in the Siu Sai Wan Elderly Center

\begin{tabular}{ccccc}
1 & 2 & 3 & 4 & 5 \\
\hline Never & Seldom & Sometimes & Usually & Always \\
Very Poor & Poor & Ordinary & Good & Excellent
\end{tabular}

1. I am involved in regular visitation or phone contact of the seekers of the Elderly Center

2. I am involved in regular visitation or phone contact of the elderly church members

3. Our church plans a high quality worship service each Sabbath

12345

4. The music in our church service is dynamic and inspirational

123345

5. The Sabbath sermons from the pastor are interesting and inspiring

6. Our church members exhibit quality care of other members regularly

7. Guests/seekers feel welcomed and cared for by our church

8. Church members regularly pray for the salvation of specific individuals

9. I routinely exhibit a passion for soul winning

10. Our church programs/events are directed towards accomplishing our missional objectives

11. Our programs/events in the church are connected to the participants

12. Our church conducts 1 to 3 outreach events per year that are respected by the elderly members of the center

13. Our outreach events are high quality

14. Our outreach events are sensitive to different the cultural, spiritual, and educational diversities 


\section{BIBLIOGRAPHY}

"Acts." Seventh-day Adventist Bible Commentary. Edited by Francis D. Nichol.

Washington, DC: Review and Herald, 1978. 6:200, 265, 309.

Anderson, R. A. "Our Worship of God." The Ministry, October 1958, 50.

Arn, Win, and Charles Arn. Catch the Age Wave: A Handbook for Effective Ministry with Senior Adults. Kansas City, MO: Beacon Hill Press, 1999.

. The Master's Plan for Making Disciples: How Every Christian Can Be an Effective Witness through an Enabling Church. Pasadena, CA: Church Growth Press, 1982.

Barna, George. The Habits of Highly Effective Churches: Being Strategic in Your GodGiven Ministry. Ventura, CA: Regal Books, 1999.

. Think Like Jesus: Make the Right Decision Every Time. Ventura, CA: Issachar Resources, 2003.

Beasley-Murray, George R. John. Word Biblical Commentary. Vol. 36. Edited by David A. Hubbard; Glenn W. Barker. Waco, TX: Word Books, 1987.

Beasley-Murray, George R. John. Word Biblical Commentary. Vol. 36. Edited by David A. Hubbard; Glenn W. Barker. Waco, TX: Word Books, 1987.

Beyer, H. W. "Eulogeo." Theological Dictionary of the New Testament. Translated by Geoffrey William Bromiley. Edited by Gerhard Kittel and Gerhard Friedrich. Grand Rapids, MI: W. B. Eerdmans, 1985. 275-277.

Burrill, Russell. Recovering an Adventist Approach to the Life and Mission of the Local Church. Fallbrook, CA: Hart Research Center, 1998.

Callahan, Kennon L. Twelve Keys to an Effective Church. San Francisco: Harper \& Row, 1983.

Ching, Julia. Chinese Religions. Maryknoll, NY: Orbis Books, 1993.

Choi, Chi-keung Desmond. "A Proposed Model of Christian Pastoral Care with the Chinese Elderly in Hong Kong." Ph.D. dissertation, Southwestern Baptist Theological Seminary, 1999. 
Chu, Pui Lan. Elderly Care and Social Work. Hong Kong: The Chinese University Press, 2001.

Creel, H. G. The Birth of China: A Study of the Formative Period of Chinese Civilization. New York: F. Ungar Publishing, 1937.

"Daniel." Seventh-day Adventist Bible Commentary. Edited by Francis D. Nichol. Washington, DC: Review and Herald, 1978. 4:751, 752.

Day, William Harold, Jr. "The Relationship of Selected Contextual and Institutional Factors to the Evangelism of Senior Adults in Churches of the Southern Baptist Convention." Ph.D. dissertation, New Orleans Baptist Theological Seminary, 1999.

De Bary, William Theodore. Sources of Chinese Tradition. New York: Columbia University Press, 1960.

Douglas, J. D., and N. Hillyer. The Illustrated Bible Dictionary. 3 vols. Wheaton, IL: Tyndale House, 1980. S.v. "Hospitality."

Dulin, Rachel Zohar. "Old Age in the Hebrew Scriptures: A Phenomenological Study." Ph.D. dissertation, Northwestern University, 1982.

"Elderly Service in Hong Kong." The Hong Kong Council of Social Service. http://www.hkcss.org.hk/download/folder/el/el_eng.htm (accessed 22 July 2009).

Esser, Hans-Helmut. "Blessing, Blessed, Happy." The New International Dictionary of New Testament Theology. 3 vols. Edited by Colin Brown. Grand Rapids, MI: Zondervan Publishing House, 1986. 1:205-215. . "Compassion." The New International Dictionary of New Testament Theology. 3 vols. Edited by Colin Brown. Grand Rapids, MI: Zondervan Publishing House, 1986. 2:593-600.

Finley, Mark. Decisions: Persuading People for Christ. Washington, DC: General Conference of Seventh-day Adventists, 1984. . Solid Ground: Daily Devotional for Adults. Hagerstown, MD: Review and Herald, 2003.

"1 Corinthians." Seventh-day Adventist Bible Commentary. Edited by Francis D. Nichol. Washington, DC: Review and Herald, 1978. 6:702, 733.

"1 Peter." Seventh-day Adventist Bible Commentary. Edited by Francis D. Nichol. Washington, DC: Review and Herald, 1978. 7:586. 
"1 Timothy." Seventh-day Adventist Bible Commentary. Edited by Francis D. Nichol. Washington, DC: Review and Herald, 1978. 7:309.

The Four Books: Confucian Analects, the Great Learning, the Doctrine of the Mean, and the Works of Mencius. Translated by James Legge. Shanghai: Chinese Book Co., 1933.

Fowler, John M. “Worship's True Motive.” Ministry, November 1993, 4-5.

"Fundamental Beliefs." Seventh-day Adventist Church. http://www.adventist.org/beliefs/ fundamental/index.html (accessed 13 April 2010).

Gallagher, David P. Senior Adult Ministry in the 21 st Century: Step-by-Step Strategies for Reaching People over 50. Eugene, OR: Wipf \& Stock, 2006.

Gentzler, Richard H. Designing an Older Adult Ministry. Nashville, TN: Discipleship Resources, 1999.

Gentzler, Richard H., and Donald F. Clingan. Aging: God's Challenge to Church \& Synagogue. Nashville, TN: Discipleship Resources, 1996.

Goebel, Joan E. "Church Revitalization through Worship Evangelism." D.Min. dissertation, University of Dubuque Theological Seminary, 2002.

Hartley, John E. Leviticus. Word Biblical Commentary. Vol. 4. Edited by David A. Hubbard; Glenn W. Barker. Waco, TX: Word Books, 1998.

"Hong Kong 2006 Population by-Census Thematic Report: Older Persons." Edited by Census and Statistics Department: The Government of Hong Kong Special Administrative Region, 2006. http://www.bycensus2006.gov.hk/FileManager/ EN/Content_962/06bc_op.pdf (accessed 26 July 2009).

"Hong Kong Population Projections 2007-2036." Edited by Census and Statistics Department: The Government of Hong Kong Special Administrative Region, 2007. http://www.censtatd.gov.hk/products_and_services/products/publications/ statistical_report/population_and_vital_events/index_cd_B112001503_dt_latest .jsp (accessed 26 July 2009).

"Hong Kong: The Fact." Hong Kong 2007. Hong Kong: Information Services Department of the Hong Kong SAR Government, 2007. http://www.yearbook.gov .hk/2007/En/pdf/Fact_Eng.pdf (accessed 22 July 2009).

Hsu, Francis L. K. Americans and Chinese: Passage to Differences. 3rd ed. Honolulu: University of Hawaii Press, 1981. 
. "Filial Piety in Japan and China: Borrowing, Variation and Significance." Journal of Comparative Family Studies 2 (Spring 1971): 67-74.

Huggins, John R. "Revitalizing Pastoral Visitation." D.Min. dissertation, United Theological Seminary, 1998.

Hunter, Kent R. Foundations for Church Growth: Biblical Basics for the Local Church. Corunna, IN: Church Growth Center, 1994.

"James." Seventh-day Adventist Bible Commentary. Edited by Francis D. Nichol. Washington, DC: Review and Herald, 1978. 7:515, 523.

"John." Seventh-day Adventist Bible Commentary. Edited by Francis D. Nichol. Washington, DC: Review and Herald, 1978. 5:948.

Johnson, Bob. You Can Witness: Yes--Even You. Lincoln, NE: AdventSource, 1995.

Kearney, Michael. World View. Novato, CA: Chandler \& Sharp, 1984.

Kidder, S. Joseph. "Education for Worship in the East Wenatchee Seventh-day Adventist Church." D.Min. dissertation, Andrews University, 1996. . Majesty: Experiencing Authentic Worship. Hagerstown, MD: Review and Herald Publishing Association, 2009. . "The Power of Relationships in Evangelism." Ministry, July 2008, 10-12.

Kim, David Myong-Uk. "A Study for Effective Ministry with the Korean-American Elderly." D.Min. dissertation, School of Theology at Claremont, 1996.

Knowles, George E. How to Help Your Church Grow. Washington, DC: Review and Herald, 1981.

Langford, Andy, and Sally Overby Langford. Worship and Evangelism. Nashville, TN: Discipleship Resources, 1989.

"Leviticus." Seventh-day Adventist Bible Commentary. Edited by Francis D. Nichol. Washington, DC: Review and Herald, 1978. 1:792.

Link, Hans-Georg. "Blessing." The New International Dictionary of New Testament Theology. 3 vols. Edited by Colin Brown. Grand Rapids, MI: Zondervan Publishing House, 1986. 1:205-215.

"Luke." Seventh-day Adventist Bible Commentary. Edited by Francis D. Nichol. Washington, DC: Review and Herald, 1978. 5:690. 
Martin, Carlos G. Turning the World Upside Down. Ontario, Canada: Pacific Press, 2000.

"Matthew." Seventh-day Adventist Bible Commentary. Edited by Francis D. Nichol. Washington, DC: Review and Herald, 1978. 5:484.

McDill, Wayne. Making Friends for Christ. Nashville, TN: Broadman Press, 1979.

McGinnis, Alan Loy. 我怎樣討人喜歡 (The Friendship Factor: How to Get Close to the People You Care for). Translated by 王伍惠亞. Chinese ed. Taipei: Taosheng, 2000.

McIntosh, Gary. Beyond the First Visit: The Complete Guide to Connecting Guests to Your Church. Grand Rapids, MI: Baker Books, 2006.

. One Size Doesn't Fit All. Grand Rapids, MI: F.H. Revell, 1999.

. Three Generations: Riding the Waves of Change in Your Church. Grand Rapids, MI: F.H. Revell, 1995.

McIntosh, Gary, and Glen Martin. Finding Them, Keeping Them: Effective Strategies for Evangelism and Assimilation in the Local Church. Nashville, TN: Broadman Press, 1992.

McPhee, Arthur G. Friendship Evangelism: The Caring Way to Share Your Faith. Grand Rapids, MI: Zondervan Publishing House, 1978.

Mittelberg, Mark, and Bill Hybels. Building a Contagious Church: Revolutionizing the Way We View and Do Evangelism. Grand Rapids, MI: Zondervan, Willow Creek Resources, 2001.

Morgenthaler, Sally. Worship Evangelism: Inviting Unbelievers into the Presence of God. Grand Rapids, MI: Zondervan Publishing House, 1995.

Nakamura, Hajime. Ways of Thinking of Eastern Peoples: India, China, Tibet, Japan. Edited by Philip P. Wiener. Honolulu: University of Hawaii Press, 1971.

Nelson, Dwight K. Pursuing the Passion of Jesus: How "Loving the Least" Helps You Fulfill God's Purpose for Your Life. Nampa, ID: Pacific Press, 2005.

Ng, Gan-Theow. "Religion, Culture, and Modernity: Some Missiological Implications of the Process of Secularization in East Asia." Ph.D. dissertation, Andrews University, 1991.

Nolland, John. Luke 1-9:20. Word Biblical Commentary. Vol. 35A. Edited by David A. Hubbard and Glenn W. Barker. Dallas, TX: Word Books, 1989. 
Oosterwal, Gottfried. The Christian in the World, Adult Sabbath School Lessons. Mountain View, CA: Pacific Press, July-September, 1982.

Paulien, Jon. John: Jesus Gives Life to a New Generation. The Abundant Life Bible Amplifier. Edited by George R. Knight. Boise, ID: Pacific Press, 1995.

Peel, William Carr, and Walt Larimore. Going Public with Your Faith: Becoming a Spiritual Influence at Work. Grand Rapids, MI: Zondervan Publishing House, 2003.

"Psalms." Seventh-day Adventist Bible Commentary. Edited by Francis D. Nichol. Washington, DC: Review and Herald, 1978. 3:845, 846, 856.

"Religion and Custom." Hong Kong 2007. Hong Kong: Information Services Department of the Hong Kong SAR Government, 2007. http://www.yearbook.gov.hk/2007/en/ pdf/E18.pdf (accessed 22 July 2009).

"Revelation." Seventh-day Adventist Bible Commentary. Edited by Francis D. Nichol. Washington, DC: Review and Herald, 1978. 7:895.

Robnett, Timothy L. "A Trinitarian Theology of Worship and Preaching with Implications for the Family Life Cycle." D.Min. dissertation, Fuller Theological Seminary, 1994.

"Romans." Seventh-day Adventist Bible Commentary. Edited by Francis D. Nichol. Washington, DC: Review and Herald, 1978. 6:622, 626.

Samaan, Philip G. Christ's Way of Reaching People. Hagerstown, MD: Review and Herald, 1990.

Sapp, Stephen. Full of Years: Aging and the Elderly in the Bible and Today. Nashville, TN: Abington Press, 1987.

Schmitz, O. "Parakaleo." Theological Dictionary of the New Testament. Translated by Geoffrey William Bromiley. Edited by Gerhard Kittel and Gerhard Friedrich. Grand Rapids, MI: Wm. B. Eerdmans, 1985. 778-782.

"Senior Citizens Card Scheme." Edited by Social Welfare Department: The Government of Hong Kong Special Administrative Region. http://www.swd.gov.hk/en/index/ site_pubsvc/page_elderly/sub_csselderly/id_seniorciti/ (accessed 26 July 2009).

Seventh-day Adventist Bible Dictionary. Edited by Siegfried H. Horn. Washington, DC: Review and Herald, 1960. S.v.v. "Bless," "Blessing," "Fellowship," "Nebuchadnezzar," "Nicodemus," "Worship." 
Sleeper, C. Freeman. Black Power and Christian Responsibility: Some Biblical Foundations for Social Ethics. Nashville, TN: Abingdon Press, 1969.

Smith, Henry Newton. "Chinese Ancestor Practices and Christianity: Toward a Variable Contextualization of Christian Ethics in a Hong Kong Setting." Ph.D. dissertation, Southwestern Baptist Theological Seminary, 1987.

Smith, Jack R. Friends Forever: Studies in Relational Evangelism. Atlanta, GA: Home Mission Board, SBC, 1994.

"Social Data Collected Via the General Household Survey: Special Topics Report-Report No. 27." Edited by Census and Statistics Department: The Government of Hong Kong Special Administrative Region, 2000. http://www.censtatd.gov.hk/ products_and_services/products/publications/statistical_report/social_data/ index_cd_B1130127_dt_latest.jsp (accessed 27 July 2009).

"Social Security Allowance Scheme." Edited by Social Welfare Department: The Government of Hong Kong Special Administrative Region. http://www.swd.gov .hk/en/index/site_pubsvc/page_socsecu/sub_ssallowance/http://www.swd.gov.hk/ en/textonly/site_whatsnew/year_1507/(accessed 22 July 2009).

Soothill, William E. The Analects of Confucius. 2nd ed. New York: Paragon Book Reprint Corp., 1968.

Spurgeon, C. H. The Treasury of David: Containing an Original Exposition of the Book of Psalms; a Collection of Illustrative Extracts from the Whole Range of Literature; a Series of Homiletical Hints Upon Almost Every Verse; and Lists of Writers Upon Each Psalm. 3 vols. Peabody, MA: Hendrickson Publishers, 19--.

Stahlin, G. "Xenia." Theological Dictionary of the New Testament. Translated by Geoffrey William Bromiley. Edited by Gerhard Kittel and Gerhard Friedrich. Grand Rapids, MI: Wm. B. Eerdmans, 1985. 661-665.

Stebbins, Tom. Evangelism by the Book: Applying First Century Principles to TwentyFirst Century Relationships. Camp Hill, PA: Christian Publications, 1995.

Strong, James. The Exhaustive Concordance of the Bible: Showing Every Word of the Text of the Common English Version of the Canonical Books; and Every Occurrence of Each Word in Regular Order. Ontario: Woodside Bible Fellowship, 1996. S.v.v. "Barak," "Hupotasso," "Parakaleo."

Tam, Stephen. 老當益壯一長者生命成長路 (Aging with Vitality: A Path for Growth). Hong Kong: Renewal Resourece (H.K.) Pte., 2000. 
Thompson, W. Oscar, Carilyn Thompson Ritzmann, and Claude V. King. Concentric Circles of Concern: Seven Stages for Making Disciples. Nashville, TN: Broadman \& Holman, 1999.

Tsang, John C. "Speech by the Financial Secretary, Moving the Second Reading of the Appropriation Bill 2008." Wednesday, 27 February 2008. http://www.budget .gov.hk/2008/eng/speech.html (accessed 26 July 2009).

Tsui, Terry. "Five-Step Witnessing Approach to Ancestor Worship." Kaohsiung Evangelistic Series, Taiwan, 2009.

Tsui, Terry, and Linda Tsui. "Elderly Evangelism: A Challenging and Rewarding Ministry." Adventist World, May 2007, 14, 15.

“2006 Population by-Census." Edited by Census and Statistics Department. Hong Kong: The Government of Hong Kong Special Administrative Region, 2006. http://www.bycensus2006.gov.hk/en/index.htm (accessed 29 July 2009).

Vine, W. E. An Expository Dictionary of New Testament Words. Nashville, TN: Thomas Nelson, 1952. S.v.v. "Beseech," "Blessed," "Blessing," "Compassion," "Worship."

Wagner, C. Peter. Church Growth and the Whole Gospel: A Biblical Mandate. San Francisco: Harper \& Row, 1981.

. Our Kind of People: The Ethical Dimensions of Church Growth in America. Atlanta, GA: John Knox Press, 1979.

. Strategies for Church Growth: Tools for Effective Mission and Evangelism. Ventura, CA: Regal Books, 1987.

Warren, Rick. The Purpose Driven Church: Growth without Compromising Your Message \& Mission. Grand Rapids, MI: Zondervan Publishing House, 1995.

Watt, David Robert. "Empowering the Laity for the Ministry of Visitation." D.Min. dissertation, Acadia Divinity College, 1999.

White, Ellen G. The Acts of the Apostles. Mountain View, CA: Pacific Press, 1911. . The Adventist Home. Nashville, TN: Southern Publishing Association, 1952. . Child Guidance. Washington, DC: Review and Herald, 1982. . Christian Service. Hagerstown, MD: Review and Herald, 2002. . Christ's Object Lessons. Mountain View, CA: Pacific Press, 1941. 
. The Desire of Ages. Mountain View, CA: Pacific Press, 1940.

. Education. Mountain View, CA: Pacific Press, 1952.

. Evangelism. Washington, DC: Review and Herald, 1946.

. Gospel Workers. Washington, DC: Review \& Herald, 1948.

. Healthful Living. Published Payson, AZ: Leaves-of-Autumn Books, 1976.

. The Ministry of Healing. Mountain View, CA: Pacific Press, 1942.

. The Pastoral Ministry. Silver Spring, MD: Ministerial Association, General Conference of Seventh-day Adventists, 1995.

. Patriarchs and Prophets. Mountain View, CA: Pacific Press, 1958.

. Prophets and Kings. Mountain View, CA: Pacific Press, 1943.

. Steps to Christ. Mountain View, CA: Pacific Press, 1956.

. Testimonies for the Church. 9 vols. Mountain View, CA: Pacific Press, 1948.

. Welfare Ministry. Washington, DC: Review and Herald, 1970.

Winter, Ralph D., and Steven C. Hawthorne. Perspectives on the World Christian Movement: A Reader. Pasadena, CA: William Carey Library, 1981.

邢福增, and 梁家麟. 中國祭祖問題 (Chinese Ancestor Worship). 香港: 建道神學院 基督教與中國文化研究中心, 1997.

周李玉珍. 松柏之音 (The Voice of the Elderly). 香港: 伯特利神學阮, 1997.

林志華. 敬拜上帝 (Worshipping God). 上海: 中國基督教兩會, 2005 .

徐松石. 聖經與中國孝道 (The Bible and Chinese Filial Piety). 香港: 浸信會出版社, 1991.

耆樂無笨一長者靈性關顧的初探與實踐 (A Joyous Golden Age: Exploration and Practice on Spiritual Care for the Older Persons). Edited by 勞家怡. 香港: 基督教靈實協會, 2004.

基督徒與敬祖 (Christian Alternatives on Ancestor Practices). Edited by 教會更新研究發展中心. 台北: 中福出版有限公司, 2000. 
陳潤棠. E-世代的民間宗教 (Folk Religions in the E-Era). Vol. III 破迷，闢邪，趕鬼！第三集 (Against Superstition, Witchcraft, and Demon Possession). 香港: 金燈臺出版社, 2003.

黃伯和等著. 基督徒與祭祖 (Christians and Ancestor Worship). 台北: 雅歌出版社, 1996.

雷子健. 人人伤道有妙法 (Everybody Ought to Know) 宣教與文化 (1) (Mission and Culture (1). 香港: 迎新有限公司, 2004.

譚司提反. 老當益壯一長者生命成長路 (Aging with Vitality: A Path for Growth). 香港: 更新資源 (香港) 有限公司, 2000. 


\section{VITA}

Name: $\quad$ Linda Muoi Tsui

Place of Birth: Cholon, Vietnam

Husband: $\quad$ Terry Man-Yuen Tsui

Education:

2004-2010

1995-2003

1989-1994

Degrees Awarded:

2010

2003

1994

\section{Degrees Awarded:}

Andrews University, U.S.A.

Adventist International Institute of Advanced Studies, the Philippines.

La Sierra University, U.S.A.

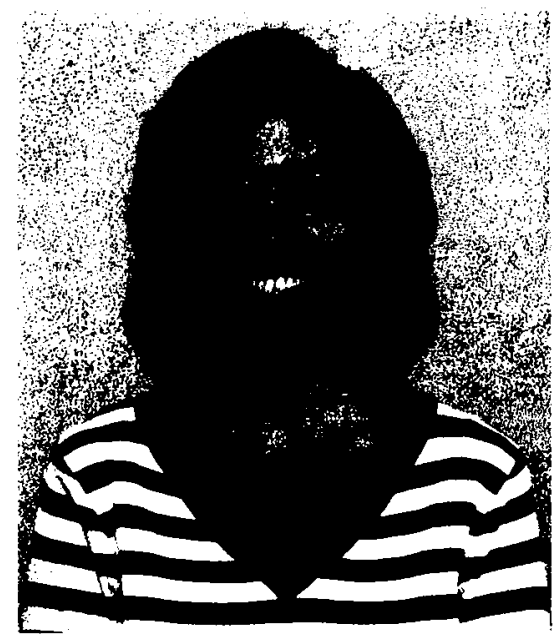

Doctor of Ministry

Master of Ministry

Bachelor of Arts in Religion

Professional Experience:

2009-present

2008-2009

2002-2007

1994-2009

1970-1978
Global Chinese Evangelism Co-Director, Chinese Union Mission

Elderly Ministry Director, Hong Kong-Macao Conference

Children Ministries Coordinator, Hong Kong-Macao Conference

Pastor, Hong Kong-Macao Conference

Primary School Teacher, Vietnam 